IESSONS on SOII. G. 2 Russell.

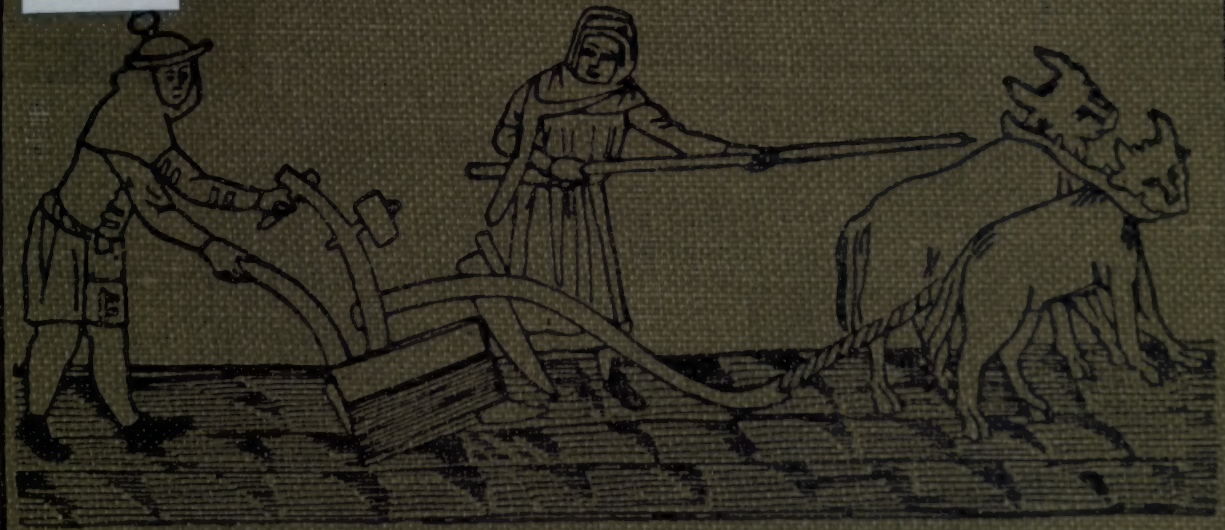

$$
\begin{aligned}
& \text { THE CAMBRIDGE } \\
& \text { NATURE STUDY SERIES }
\end{aligned}
$$




The Cambridge Nature Study Series

General Editor: Hugh Richardson, M.A.

\section{LESSONS ON SOIL}


CAMBRIDGE UNIVERSITY PRESS

C. F. Clay, Manager

LONDON : FETTER LANE, E.C. 4

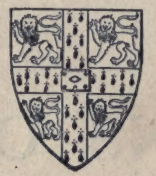

NEW YORK : THE MACMILLAN CO. BOMBAY

CALCUTTA MACMILLAN AND CO., LTD. MADRAS

TORONTO : THE MACMILLAN CO. OF CANADA, LTD.

TOKYO : MARUZEN-KABUSHIKI-KAISHA

ALL RIGHTS RESERVED 


\section{LESSONS ON SOIL}

BY

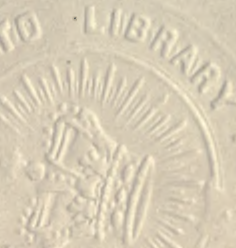

(Sir) E. J. RUSSELL, D.Sc., F.R.S. DIRECTOR OF THE ROTHAMSTED EXPERIMENTAL STATION HARPENDEN

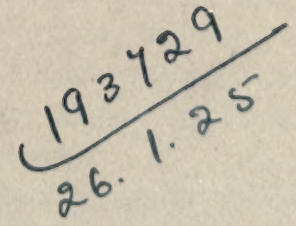

Cambridge:

at the University Press

1922 


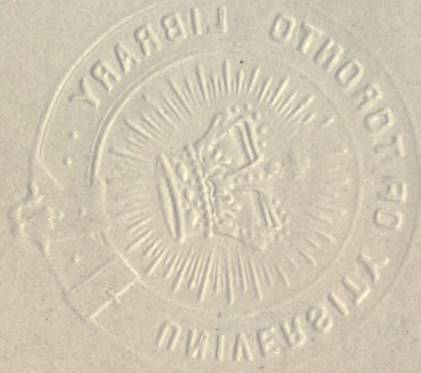

First Edition 191

Reprinted 1912, 192 ( 922. 


\section{PREFACE}

THE Syndics of the Cambridge University Press propose to issue a Nature Study Series of which this is the first volume.

We count ourselves fortunate in securing Dr E. J. Russell as author and Soil as subject. The subject is fundamental, for, just as the soil lies beneath the plant and animal life we see, so is a knowledge of the soil necessary for all therstanding of flora and fauna. The real complexity the apparently simple element "Earth," and the var ety of methods required for exploring it, are typic d of the problems which the tout ensemble of the outdoor world presents to the naturalist.

Dr E. J. Russell has not only acquired a first-rate and first-hand knowledge of his subject at Wye and at Rothamsted; his own researches have recently extended our knowledge of the micro-organisms in the soil and their influence on fertility. Further, what is very much to our purpose, he has himself had practical experience in teaching at an elementary school in Wye and at a secondary school in Harpenden.

Just at the present moment, County Councils are trying to push rural education and to awaken the intelligence of country children by interesting them in their surroundings. It is, therefore, a favourable opportunity to offer these pages as a concrete suggestion in model lessons and object lessons, showing exactly what can be done under existing conditions. 
The book is intended to help children to study nature; there is no attempt to substitute book study for nature study. Hence, whilst there are passages of continuous reading, it is not a mere "reader." Many teachers, myself among them, have felt the difficulty of organising practical work for large classes. Dr Russell has written so that, whilst nominally showing the pupil how to learn, he is secretly scattering hints for the teacher who is learning how to teach.

Abundant and varied practical exercises have been suggested, and careful instructions have been given so that the book shall seem intelligible even in the absence of a teacher. The proposed practical work is not only what might be done by eager boys and girls on half-holidays, but what can be done by every scholar in the course of ordinary school work. The pictorial illustrations are intended as aids to observation, not as substitutes. Drawing is one form of practical exercise, and the preparation of corresponding illustrations in the scholars' notebooks from the apparatus used in the classroom and the fields around the school may afford exercises in artistic work with pen, brush or camera.

Sufficient directions are given for the supply of necessary materials and apparatus. The apparatus proposed is of the simplest character.

It is suggested that the book will be found most useful in the higher standards of elementary schools, in preparatory schools and in the lower forms of secondary schools, that is, where the ages of scholars average from 12 to 14 .

\section{HUGH RICHARDSON}

York, 7 January 1911 


\section{CONTENTS}

CHAP.

PAGK

I. WHAT IS THE SOII MADE OF? . . . 1

II. MORE $\triangle B O U T$ THE CLAT . $\quad$ - $\quad$. 9

III. WhAT LIME DOWS TO CLAY . . . 19

IV. SOME EXPERIMENTS WITH THE SAND . . 22

V. THE PART THAT BURNS AWAT . . . 33

VI. The plaNT EOOD IN the soIt. . . 41

VII. THE DWELLER IN THE SOIL . . : 53

VIII. THE SOIL AND THE PLANT . . . 64

IX. Culmitation and thliak . . . 82

X. THE SOIL AND THZ COUNTRYSIDE . 100

XI. How SOIL HAS BEKN MADK . 116

APPENDIX . . . . . . . 128

INDKX . . . . . . . 132 



\section{LIST OF ILLUSTRATIONS}

FTOURE

1. Soil and subsoil in St George's School garden

2. Columns showing what 100 parts of soil and subsoil were made of

3. Columns showing what 100 parts of ${ }^{\circ}$ dried soil and subsoil were made of . . . . . .

4. Clay shrinks when it dries . . . . . .

5. Clay swells up when it is placed in water . .

6. Landslip at Seaton, Devonshire. Phot. Valentine \& Son

7. Clay does not let water run through . . . .

8. Sand allows air to pass through but clay does not .

9. A brick allows both air and water to pass through it

10. Lime added to turbid clay water soon makes the clay settle.

11. Sand dunes, Penhale, Cornwall. Phot. Geological Survey

12. Blowing sand covering up meadows and ruining them. Phot. Geological Survey . . . . . .

13. Model of a spring . . * * : *

14. Foot of chalk hill at Harpenden where a spring breaks out. Phot. Lionel Armstrong . . .

15. The little pool and the spring. Phot. Lionel Armstrong

16. Water spouting up from a bore hole, Old Cateriag Quarry, Dunbar. Phot. Geological Survey . .

17. Sandy soils in wet and in dry positions . .

18 Map of the roads round Wye 1 . Peat bog in Hoy, Orkney: peat is being cut for fuel. Phot. Valentine \& Son . . . . .

20. Rye growing in surface soil, subsoil, and sand :

21. Mustard growing in surface soil, subsoil, and sand .

22. Mustard growing in soil previously cropped with rye, and in soil previously uncropped

23. Pieces of grass, leaves, etc. change to plant food in the surface soil but not in the subsoil

24. Soil in which earthworms have been living and making burrows

25. Fresh soil turns milk bad, but baked soil does not :

26. Soil contains tiny living things that grow on gelatine

27. Our breath makes lime water turn milky .

28. Something in the soil uses up air and makes lime water turn milky .

29. Soils are able to stick to water : clay or loam soils do this better than sands

30. Water can pass from wet to dry places in the soil, it can even travel upwards.

31. Plants growing in soils supplied from below with wator. All the water the plants get has to travel upwards .

32. Mustard growing in soils supplied with varying quantities of water 
FIGURE

33. Wheat growing in moist and in dry soils .

$34 a$ and $b$. Plants found on a dry soil had narrow leaves, those on a moist soil had wider leaves, Phot. S. T. Parkinson .

35. Plants give out water through their leaves ${ }^{*} \cdot$

36. Stephen Hales's experiment in 1727

37. Hill slope near Harpenden showing woodland at top and arable land lower down. Phot. Lionel Armstrong .

38. View further along the valley; woodland and arable above, rough grassland near the river. Phot. Lionel Armstrong:

39. Rough grass pasture near the river. Higher up is arable land. Phot. Lionel Armstrong

40. After harvest the farmer breaks up his land with a plough and then leaves it alone until seed time. Phot. Lionel Armstrong . - p

41. Rolling in mangold seed on the farm. Phot. $\dot{H}$. $\dot{B}_{\text {. }}^{\circ}$ Hutchinson . - . . . .

42. Soil sampler

43. Cultivation and mulching reduce the loss of water from

$44 a$ and $b$. Maize cannot compete successfully with weeds

45. A plot of wheat left untouched since 1882 at Rothamsted has now become a dense thicket. Phot. Lionel Armstrong

46. A badly drained wheat field: $\quad \cdot \quad \cdot \quad \cdot \quad \cdot \quad \cdot \quad \cdot \quad \cdot$

47. Highly cultivated sandy soil in Kent . . . . 103

48. A Surrey heath . $\quad . \quad$. 105

49. Woodland and heather on high sandy land, Wimbledon Common. Phot. R. H. Carter .

50. Poor sandy soil in Surrey, partly cultivated but mainly wood and waste

51. Open chalk cultivated country, Thanet. :

52. Cliffs at the seaside, Manorbier. Phot. Geological

53. Cliffs in inland district, Arthur's Seat, Ėdinburgh. Phot. Geological Survey .

54. Model of a stream .

55. The bend of a river

56. The winding river-the Stour at Wye. Phot. $\dot{\mathrm{R}} \mathrm{H}$.

57. Sketch map showing why Godmersham and Wye arose where they did on the Stour.

58. Ford at Coldharbour near Harpenden. Phot. Lionel Armstrong

The photographs of the pot experiments are by Mr Lionel Armstrong. 


\section{INTRODUCTION}

THE following pages contain the substance of lessons given at the village school at Wye to the $4 \mathrm{th}, 5$ th, 6 th and 7 th standards (mixed) and at St George's School, Harpenden, to the 3rd form. There is, however, an important difference between the actual lessons and the book. The lessons had reference to the soils round about the village, and dealt mainly with local phenomena, general conclusions being only sparingly drawn; while in the book it has been necessary to throw the course into a more generalised form. The teacher in using the book will have to reverse the process, he must find local illustrations and make liberal use of them during the course; it is hoped that the information given will help him over any difficulties he may experience.

This necessity for finding local illustrations constitutes one of the fundamental differences between Nature Study subjects and other subjects of the school curriculum. The textbook in some of the others may be necessary and sufficient; in Nature Study it is at most only subsidiary, serving simply as a guide to the thing that is to be studied; unless the thing itself be before the class it is no better than a guide to a cathedral would be without the cathedral. And just as the guide is successful only when he directs the attention of the stranger to the important features of the place, and fails directly he becomes garrulous and distracts attention, so a Nature Study book succeeds 
only in as far as it helps in the study of the actual thing, and fails if it is used passively and is substituted for an active study. No description or illustration can take the place of direct observation; the simplest thing in Nature is infinitely more wonderful than our best word pictures can ever paint it.

The author recommends the teacher to look through the chapter before it has to be taken in class and then to make a few expeditions in search of local illustrations. It is not strictly necessary that the chapters should be taken in the order given. The local phenomena must be dealt with as they arise and as weather permits, or the opportunity may pass not to return again during the course. In almost any lane, field, or garden a sufficient number of illustrations may be obtained for our purpose; if a stream and a hill are accessible the material is practically complete, especially if the children can be induced to pursue their studies during their summer holiday rambles. Of course this entails a good deal of work for the teacher, but the results are worth it. Children enjoy experimental and observation lessons in which they take an active part and are not merely passive learners. The value of such lessons in developing their latent powers and in stimulating them to seek for knowledge in the great book of Nature is a sufficient recompense to the enthusiastic teacher for the extra trouble involved.

It is not desirable to work through a chapter in one lesson. Children unaccustomed to make experiments or to see experiments done, will probably require three or four lessons for getting through each of the first few chapters, and two or three lessons for each of the others. 
The pot experiments of Chaps. VI., VII. and vIII. should be started as early in the course as possible. Twenty flower pots are wanted for the set; they should be of the same size, about eight inches being a convenient diameter, and should be kept together in a warm place. Three are filled with sand, seven with subsoil, and the remaining ten with surface soil. Three of the subsoil pots are uncropped, two being stored moist and one dry. Four pots of the surface soil are uncropped and moist, a fifth and sixth are uncropped and dry, one of these contains earthworms (p. 54). Four glazed pots, e.g. large jam or marmalade jars, are also wanted (p. 69). Mustard, buckwheat, or rye make good crops, but many others will do. Leguminous crops, however, show certain abnormal characters, while turnips and cabbages are apt to fail : none of these should be used. It is highly desirable that the pots should be duplicated.

The plots also should be started in the school garden as early as convenient. Eight are required for the set: their treatment is described in Chap. Ix. Plots two yards square suffice.

A supply of sand, of clay, and of lime will be wanted, but it is not necessary to have fresh material for each lesson. The sand may be obtained from a builder, a sand pit, the sea shore or from a dealer in chemical apparatus. The clay may be obtained from a brick yard; it gives most satisfactory results after it has been ground ready for brick making. Modelling clay is equally satisfactory. A supply of rain water is desirable.

For a class of twelve children working in pairs at the experiments the following apparatus is wanted for the whole course:- 
xiv

Six tripods and bunsen burners or spirit lamps [2]

twelve pipe-clay triangles [4]

twelve crucibles or tin lids [3]

sixteen gas jars [4]

twelve beakers 250 c.c. capacity [4]

two beakers 500 c.c.

two beakers 100 c.c.

six egg-cups [2]

twelve funnels [3]

six funnel stands [1]

six perforated glass disks [3]

two tubulated bottles 500 c.c., four corks to fit

cork borers

4 lbs. assorted glass tubing

pestle and mortar

twelve Erlenmeyer flasks 50 c.c. [3]

six saucers

twelve flatbottomed flasks 100 c.c., six fitted with India rubber stoppers bored with one hole [3], and six with ordinary corks [3]

box as in Fig. 13

six glass tubes $\frac{1}{2}$ " diameter, 18" long [2]

six straight lamp chimneys [3]

six test tubes, corks to fit

three Factory thermometers with stems 6 inches long

soil sampler (p. 88)

balance and weights

two retort stands with rings and clamp.

The figures given in square brackets are the quantities that suffice when the teacher alone does the experiments, it not being convenient for the scholars to do much. 
In conclusion the author desires to tender his best thanks to the Rev. Cecil Grant of St George's School, and to $\mathrm{Mr}$ W. J. Ashby of the Wye School, for having allowed him the use of their schools and appliances during the progress of these lessons. Especially are his thanks due to Mr Lionel Armstrong for much help ungrudgingly rendered in collecting material, taking photographs, and supervising the experiments.

E. J. R.

HARPENDEN,

February, 1911. 



\section{OHAPTER I}

\section{WHAT IS THE SOIL MADE OF?}

\section{Apparatus required.}

Soil and subsoil from a hole dug in the garden. Clay. Six tripods and bunsen burners or spirit lamps [2]. Six crucibles or tin lids and pipe-clay triangles [2]. Twelve glass jars or gas cylinders [4]. Six beakers [2] $]^{1}$.

If we talk to a farmer or a gardener about soils he will say that there are several kinds of soil ; clay soils, gravel soils, peat soils, chalk soils, and so on, and we may discover this for ourselves if we make some rambles in the country and take careful notice of the ground about us, particularly if we can leave the road and walk on the footpaths across the fields. When we find the ground very hard in dry weather and very sticky in wet weather we may be sure we are on a clay soil, and may expect to find brick yards or tile works somewhere near, where the clay is used. If the soil is loose, drying quickly after rain, and if it can be scattered about by the hand like sand on the sea shore, we know we are on a sandy soil and can look for pits where builder's sand is dug. But it may very likely happen that the soil is something in between, and that neither sand pits nor

3 See p. xiv for explanation of the figures in square brackets.

r. 
clay pits can be found; if we ask what sort of soil this is we are told it is a loam. A gravel soil will be known at once by its gravel pits, and a chalk soil by the white chalk quarries and old lime kilns, while a peat soil is black, sometimes marshy and nearly always spongey to tread on.

We want to learn something of the soil round about us, and we will begin by digging a hole about three feet deep to see what we can discover. At Harpenden this is what the scholars saw:- the top eight inches of soil was dark in colour and easy to dig; the soil below was reddish brown in colour and very hard to dig; one

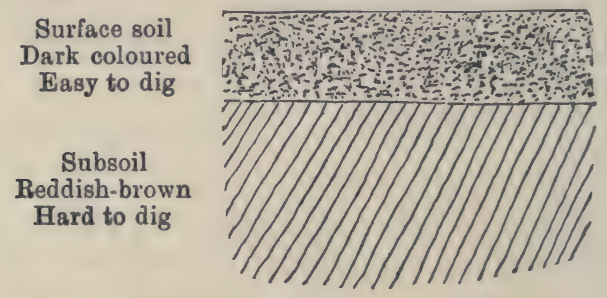

Fig. 1.

Soil and subsoil in St George's school garden

changed into the other so quickly that it was easy to see where the top soil ended and the bottom soil began; no further change could, howevēr, be seen below the eight inch line. A drawing was made to show these things, and is given in Fig. 1. You may find something quite different: sand, chalk, or solid rock may occur below the soil, but you should enter whatever you see into your notebooks and make a drawing, like Fig. 1, to be kept for future use. Before filling in the hole some of the dark coloured top soil, and some of the lighter coloured soil lying below (which is called the subsoil), 
should be taken for further examination; the two samples should be kept separate and not mixed.

First look carefully at the top soil and rub some of it between your fingers. We found that our sample was wet and therefore contained water; it was very sticky like clay and therefore contained clay; there were a few stones and some grit present and also some tiny pieces of dead plants-roots, stems or leaves, but some so decayed that we could not quite tell what they were. A few pieces of a soft white stone were found that marked on the blackboard like chalk. Lastly, there were a few fragments of coal and cinders, but as these were not a real part of the soil we supposed they had got in by accident. The subsoil was also wet and even more sticky than the top soil, it contained stones and grit, but seemed almost free from plant remains and from the white chalky fragments.

A few experiments will show how much of some of these things are present. The amount of water may be discovered by weighing out ten grams of soil, leaving it to dry in a warm place near the fire or in the sun, and then weighing it again. In one experiment the results were :-

Weight of top soil before drying

... 10 grams $=100$ decigrams

$$
" \quad " \quad \text { Water lost } \quad \ldots \quad \ldots \frac{8.3}{1 \cdot 7},=\frac{83}{17},
$$

A column 100 millimetres long was drawn to represent the 100 decigrams of soil, and a mark was drawn 17 millimetres up to show the amount of water (see Fig. 2).

Weight of bottom soil before drying ... 10 grams $=100$ decigrams

$$
\begin{aligned}
& \text { " " after } \quad \ldots \quad 8.7,=87 \text { " } \\
& \text { Water lost } \ldots \quad \ldots \overline{1 \cdot 3} n=\overline{13} \text {, }
\end{aligned}
$$


Another column should be drawn for the subsoil. On drying the soil it becomes lighter in colour and loses its stickiness, but it has not permanently changed because as soon as water is added it comes back to what it was before.

The dried lumps of soil are now to be broken up

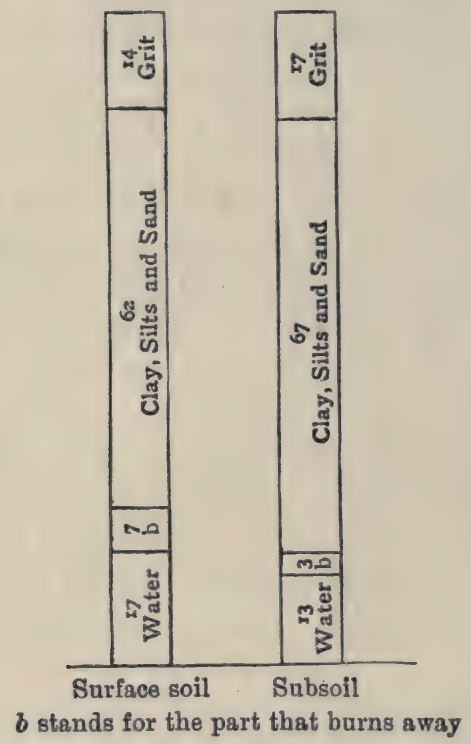

Fig. 2.

Columns showing what 100 parts of soil and subsoil were made of

finely with a piece of wood, but nothing must be lost. It is easy to see shrivelled pieces of plant, but not easy to pick them out; the simplest plan is to burn them away. The soil must be carefully tipped on to a tin lid, or into a crucible, heated over a flame and stirred 
with a long clean nail. First of all it chars, then there is a little sparkling, but not much, finally the soil turns red and does not change any further no matter how much it is heated. The shade of red will at once be recognised as brick red or terra cotta, indeed "terra cotta" means "baked earth." When the soil is cold it should be examined again; it has become very hard and the plant remains have either disappeared or have changed to ash and crumble away directly they are touched. On weighing a further loss is discovered, which was in our experiment :-

Weight of top soil after drying but before burning... 83 decigrams

The part that burnt away weighed $\ldots \quad \ldots \quad \ldots \quad \frac{}{7} \quad$ "

Weight of subsoil after drying but before burning ... 87 decigrams

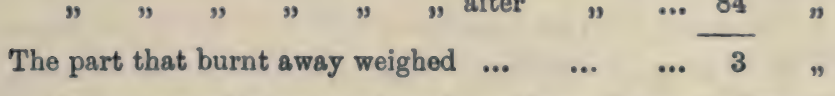

These results are entered on the column in Fig. 2.

The surface soil is seen to contain more material that will burn away than the subsoil does. When the burnt soil is moistened it does not become dark and sticky like it did before, it has completely changed and cannot be made into soil again. It is more like brick dust than soil.

For further experiments we shall want a fresh portion of the original soil.

On a wet afternoon something was noticed that enabled us to get a little further with our studies. The rain water ran down a sloping piece of ground in a tiny channel it had made; the streamlet was very muddy, and at first it was thought that all the soil was washed away. But we soon saw that the channel was lined 
with grit, some of which was moving slowly dowu and some not at all. Grit can therefore be separated from the rest of the soil by water.

This separation can be shown very well by the following experiment. Rub ten grams of finely powdered soil with a little water (rain water is better than tap water), and carefully pour the muddy liquid into a large glass jar. Add more water to the rest of the soil, shake, and again pour the liquid into the jar; go on doing this till the jar is full. Then get some more jars and still keep on till the liquid is no longer muddy but nearly clear. The part of the soil that remains behind and will not float over into the jars is at once seen to be made up of small stones, grit, and sand. Set the jars aside and look at them after a day or so. The liquid remains muddy for some time, but then it clears and a thick black sediment gathers at the bottom. If now you very carefully pour the liquid off you can collect the sediments: they are soft and sticky, and can be moulded into patterns like clay. In order to see if they really contain clay we must do the experiment again, but use pure clay from a brick yard, or modelling clay, instead of soil. The muddy liquid is obtained as before, it takes a long time to settle, but in the end it gives a sediment so much like that from the soil, except in colour, that we shall be safe in saying that the sediments in the jars contain the clay from the soil. And thus we have been able to separate the sticky part of the soil-the clay-from the gritty or sandy part which is not at all sticky. We may even be able to find out something more. If we leave the soil sediment and the clay sediment on separate tin lids to dry, and then examine them carefully we may find that the 
soil sediment is really a little more gritty than the clay. Although it contains the clay it also contains something else.

When the experiment is made very carefully in a proper way this material can be separated from the pure clay. It is called silt, but really there are a number of silts, some almost like clay and some almost like sand; they shade one into the other.

If there is enough grit it should be weighed: we obtained 14 decigrams of grit from 10 grams of our top soil and 17 decigrams from 10 grams of bottom soil. We cannot separate the clay from the silt, but when this is done in careful experiments it is found that the subsoil contains more clay than the top soil. We should of course expect this because we have found that the subsoil is more sticky than the top soil. These results are put into the columns as before so that we can now see at once how much of our soil is water, how much can burn away, how much is grit, and how much is clay and other things.

What would have happened if the sample had been dug out during wetter or drier weather? The quantity of water would have been different, but in other respects the soil would have remained the same. It is therefore best to avoid the changes in the amount of water by working always with 10 grams of $d r i e d$ soil. The results we obtained were :-

Weight of dry soil before burning

Top soil Subsoil

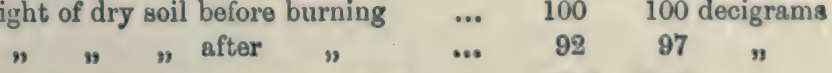

The part that burned away weighed ...

Weight of grit from 10 grams of dried soil

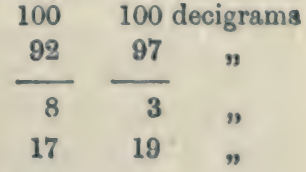

The columns are given in Fig. 3. 
summary. The experiments made so far have taught us these facts:-

1. Soil contains water, grit or sand, silt, clay, a part that burns away, and some white chalky specks.

2. The top layer of soil to a depth of about eight inches is different from the soil lying below, which is

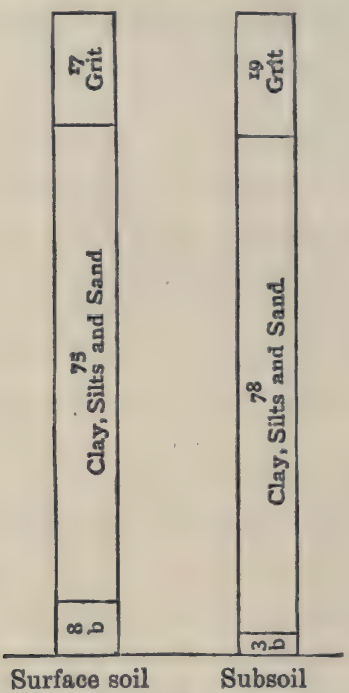

$b$ stands for the part that burns away

Fig. 3.

Columns showing what 100 parts of dried

soil and subsoil were made of

called the subsoil. It is less sticky, easier to dig, and darker in colour. It contains more of the material that burns away, but less clay than the subsoil.

3. When soil is dried it is not sticky but hard or crumbly; as soon as it is moistened it changes back to what it was before. But when soil is burnt it completely alters and can no longer be changed back again. 


\section{OHAPTER II}

\section{MORE ABOUT THE CLAY}

\section{Apparatus required.}

Clay, about 6 lbs.; a little dried, powdered clay; sand, about 6 lbs. Six glass jars or cylinders [2]. Six beakers [1]. Six egg-cups [1]. Six funnels and stands [2]. Six perforated glass or tin disks [2]. Six glass tubes [2]. Two tubulated bottles fitted with corks. Some seeds. Six small jars about 2 in. $\times 1$ in. [2]. Bricks. The apparatus in Fig. 9. Pestle and mortar.

We have seen in the last chapter that clay will float in water and only slowly settles down. Is this because clay is lighter than water? Probably not, because a lump of clay seems very heavy. Further, if we put a small ball of clay into water it at once sinks to the bottom. Only when we rub the clay between our fingers or work it with a stick-in other words, when we break the ball into very tiny pieces - can we get it to float again. We therefore conclude that the clay floated in our jars (p. 6) for so long not because it was lighter than water, but because the pieces were so small.

Clay is exceedingly useful because of its stickiness. Dig up some clay, if there is any in your garden, or procure some from a brick works. You can mould it into any shape you like, and the purer the clay the 
better it acts. Enormous quantities of clay are used for making bricks. Make some model bricks about an inch long and half an inch in width and depth, also make a small basin of about the same size, then set them aside for a week in a warm, dry place. They still keep their shape; even if a crack has appeared the pieces stick together and do not crumble to a powder.

.If you now measure with a ruler any of the bricks that have not cracked, you will find that they have shrunk a little and are no longer quite an inch long. This fact is well known to brickmakers; the moulds in which they make the bricks are larger than the brick is wanted to be. But what would happen if instead of a piece of clay one inch long you had a whole field of clay? Would that shrink also, and, if so, what would the field look like? We can answer this question in two ways ; we may make a model of a field and let it dry, and we can pay a visit to a clay meadow after some hot, dry weather in summer. The model can be made by kneading clay up under water and then rolling it out on some cardboard or wood as if it were a piece of pastry. Cut it into a square and draw lines on the cardboard right at the edges of the clay. Then put it into a dry warm place and leave for some days. Fig. 4 is a picture of such a model after a week's drying. The clay has shrunk away from the marks, but it has also shrunk all over and has cracked. If you get an opportunity of walking over a clay field during a dry summer, you will find similar but much larger cracks, some of which may be two or three inches wide, or even more. Sometimes the cracking is so bad that the roots of plants or of trees are torn by it, and even buildings, in some instances, have suffered through their foundations shrinking away. 
We can now understand why some of our model bricks cracked. The cracks were caused by the shrinkage just as happens with our model field. As soon as the clay becomes wet it swells again. A very pretty experiment can be made to show this. Fill a glass tube or an egg-cup with dry powdered clay, scrape the surface level with a ruler, and then stand in a glass jar full of rain water so that the whole is completely covered. After a short time the clay begins to swell and forces

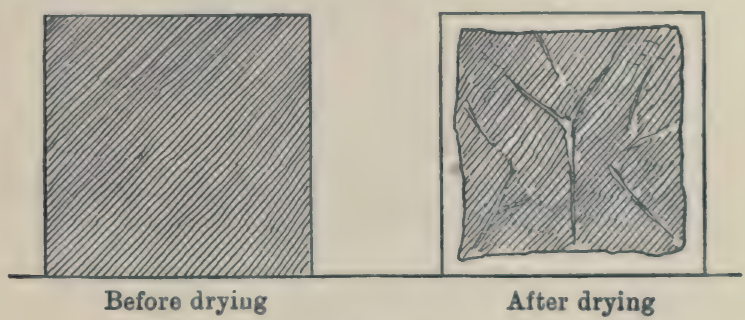

Fig. 4.

Clay was plastered over a square piece of board and completely covered it. After drying for a week the olay had shrunk and oracked

its way out of the egg-cup as shown in Fig. 5, falling over the side and making quite a little shower. In exactly the same way the ground swells after heavy rain and rises a little, then it falls again and cracks when it becomes dry. Darwin records some careful measurements in a book called Earthworms and Vegetable Mould-"a large flat stone laid on the surface of a field sank $3: 33$ millimetres ${ }^{1}$ whilst the weather was dry between May 9th and June 13th,

1 A little more than one-eighth of an inoh. 
and rose 1.91 millimetres between September 7th and 19th of the same year, much rain having fallen during the latter part of this time. During frosts and thaws the movements were twice as great."

You must have found out by now how very slippery clay becomes as soon as it is wet enough. It is not easy to walk over a clay field in wet weather, and if the clay forms part of the slope of a hill it may be so slippery that it becomes dangerous. Sometimes after very heavy rains soil resting on clay on the side of a hill has begun

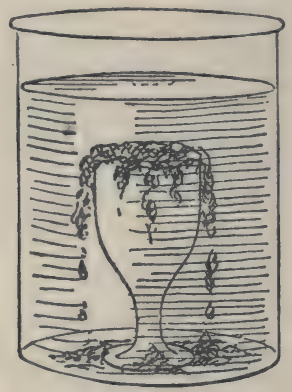

Fig. 5.

Clay swelling up when placed in water and overflowing from the egg-cup into which it was put

to slide downwards and moves some distance before it stops. Fortunately these land slips as they are called, are not common in England, but they do occur. Fig. 6 shows one in Devonshire, and another is described by Gilbert White in The Natural History of Selborne.

Another thing that you will have noticed is that anything made of clay holds water. A simple way of testing this is to put a round piece of tin perforated 


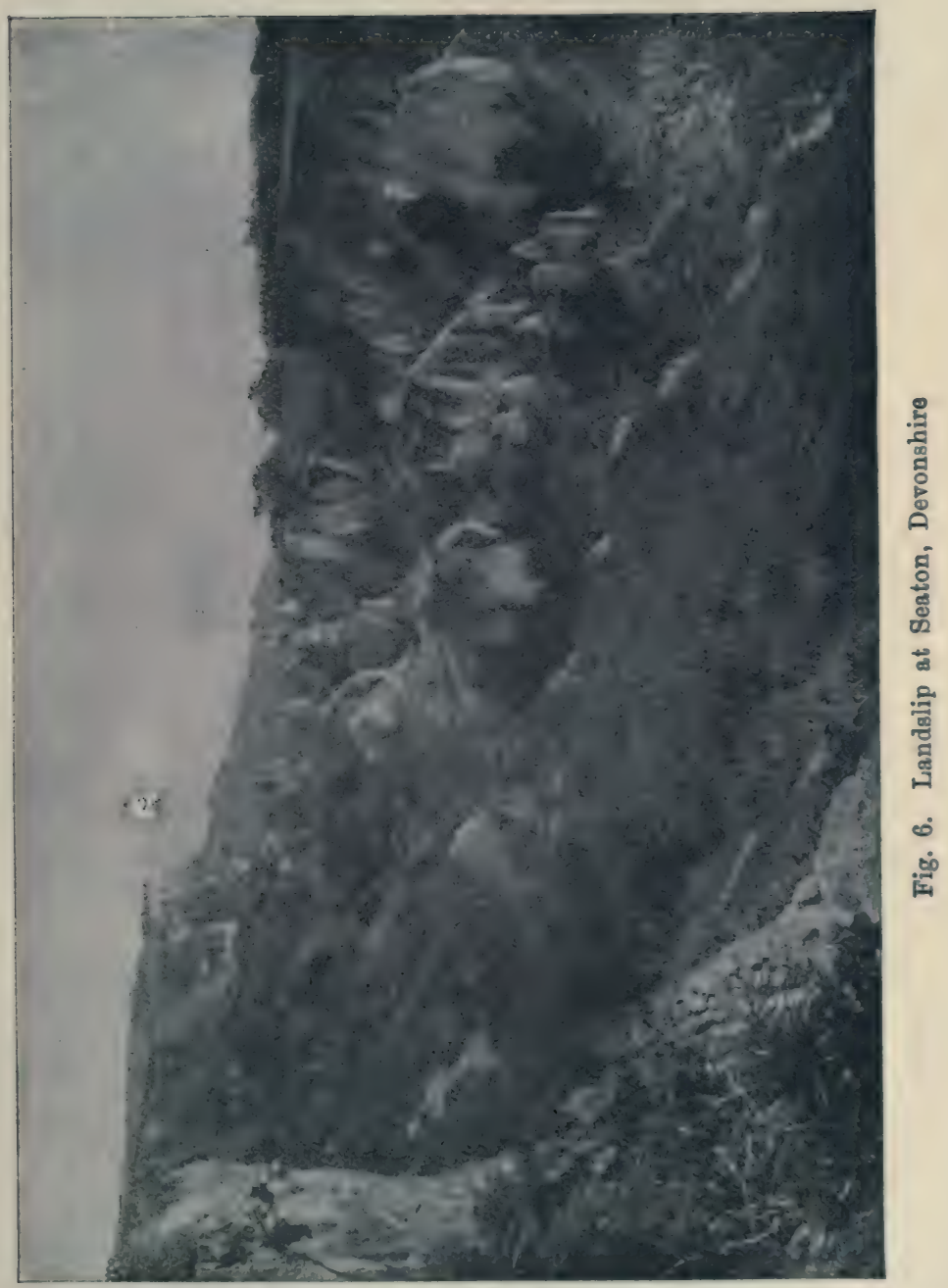


with holes into a funnel, press some clay on to it and on to the sides of the funnel (Fig. 7), and then pour on rain water. The water does not run through. Pools of water may lie like this on a clay field for a very long time in winter before they disappear, as you will know very well if you live in a clay country. So when a lake or a reservoir is being made it sometimes happens that the sides are lined with clay to keep the water in.

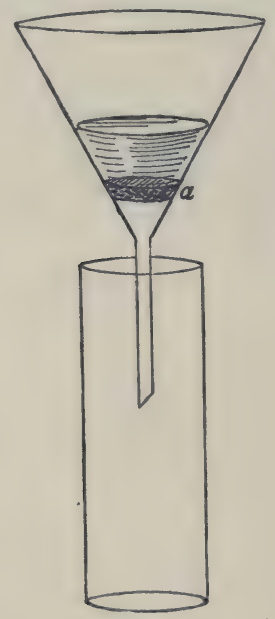

Fig. 7.

A thin layer of clay $a$ entirely prevents the water running through

If water cannot get through can air? This is very easily discovered: plug a glass tube with clay and see if you can draw or blow air through. You cannot. Clay can be used like putty to stop up holes or cracks, and so long as it keeps moist it will neither let air nor water 
through. Take two bottles like those in Fig. 8, stop up the bottom tubes, and fill with water. Then put a funnel through each cork and fit the cork in tightly, covering with clay if there is any sign of a leak. Put a perforated tin disk into each funnel, cover one well with clay and the other with sand. Open the bottom

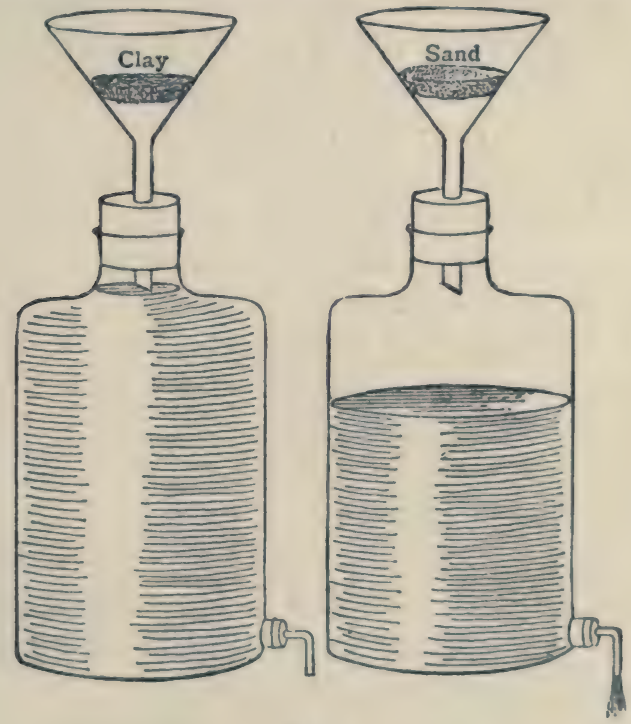

Fig. 8.

Sand allows air to pass through it, and so water runs out of the bottle. Clay does not let air pass, and the water is therefore kept in, even though the tube is open.

tubes. No water runs out from the first bottle because no air can leak in through the clay, but it runs out very quickly from the second because the sand lets air through. These properties of clay and sand are very important for plants. Sow some seeds in a little jar 
full of clay kept moist to prevent it cracking, and at the same time sow a few in some moist sand. The seeds soon germinate in the sand but not in the clay. It is known that seeds will not germinate unless they have air and water and are warm enough. They had water in both jars, and they were in both cases warm, but they got no air through the clay and therefore could not sprout. Pure clay would not be good for plants to grow in. Air came through the sand, however, and gave the seeds all they wanted for germination.

This also explains something else that you may have noticed. If you tried baking one of your model bricks in the fire you probably found that the brick exploded and shattered to pieces: the water still left in the brick changed to steam when it was heated, but the steam could not escape through the clay, and so it burst the clay. In a brick works the heat is very gradually applied and the steam only slowly forms, so that it has time to leak away, then when it has all gone the brick can be heated strongly. You should try this with one of your model bricks; leave it in a hot place near the stove or on the radiator for a week or more and then see if you can bake it without mishap.

Let us now compare a piece of clay with a brick. The differences are so great that you would hardly think the brick could have been made from clay. The brick is neither soft nor sticky, and it has not the smooth surface of a piece of clay, but is full of little holes or pores, which look as if they were formed in letting the steam out. A brick lets air through; some air gets into our houses through the bricks even when the windows are shut. Water will get through bricks more easily than it does through clay. After heavy rain you 
can often find that water has soaked through a brick wall and made the wall paper quite damp. A pretty experiment can be made with the piece of apparatus shown in Fig. 9: bore in a brick a hole about an inch deep and a quarter of an inch wide, put into the hole the piece of bent glass tubing, and fix it in with some clay or putty, then pour some water blackened with ink into the tube, marking its position with a label. Stand the brick in a vessel so full of water that the brick

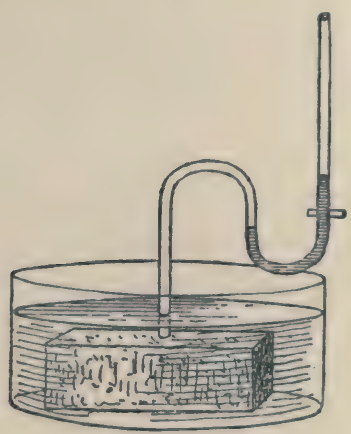

Fig. 9.

$A$ brick standing in water. The air in the brick is driven inwards by the water and forces the liquid up the tube in order to escape

is entirely covered. Water soaks into the brick and presses the air out: the air tries to escape through the tube and forces up the black liquid.

One more experiment may be tried. Can a brick be changed back into clay? Grind up the brick and it forms a gritty powder. Moisten it, work it with your fingers how you please, but it still remains a gritty powder and never takes on the greasy, sticky feeling of

R. 
pure clay. Indeed no one has ever succeeded in making clay out of bricks. All these experiments show that clay is completely altered when it is burnt. We also found that soil is completely altered by burning, and if you look back at your notes you will see that the changes are very much alike, so much so that we can safely put down some of the changes in the burnt soilthe red colour, the hard grittiness, and the absence of stickiness-to the clay. Let us now examine a piece of dry, but unburnt, clay. It is very hard and does not crumble, it is neither sticky nor slippery. Directly, however, we add some water it changes back to what it was before. Drying therefore alters clay only for the time being, whilst baking changes it permanently. 


\section{CHAPTER III}

\section{WHAT LIME DOES TO CLAY}

\section{Apparatus required.}

Clay, about 6 lbs. Some of the clay from Chapter II may, if necessary, be used over again. Lime, about $\frac{1}{2} l b$. Six funnels, stands and disks [2]. Twelve glass jars [2]. Lime water.

If you are in a clay country in autumn or early winter you will find some of the fields dotted with white heaps of chalk or lime, and you will be told that these things "improve" the soil. We will make a few experiments to find out what lime does to clay. Put some clay on to a perforated tin disk in a funnel just as you did on p. 14, press it down so that no water can pass through. Then sprinkle on to the clay some powdered lime and add rain water. Soon the water begins to leak through, though it could not do so before; the addition of the lime, therefore, has altered the clay. If you added lime to a garden or a field on which water lay about for a long time in winter you would expect the water to drain away, especially if you made drains or cut some trenches along which the water could pass. There are large areas in England where this has been done with very great advantage.

1 Lime water is made by shaking up lime and water. It should be kept in a well-corked bottle. 
The muddy liquid obtained by shaking clay with water clears quickly if a little lime is stirred in. Fill two jars $A$ and $B$ (Fig. 10) with rain water, rub clay into each and stir up so as to make a muddy liquid, then add some lime water to $B$ and stir well. Leave for a short time. Flocks quickly appear in $B$, then sink, leaving the liquid clear, but $\boldsymbol{A}$ remains cloudy for a long time. But why should the liquid clear? We decided in our earlier experiments that the clay floated in the water because it was in very tiny pieces; when we took a larger lump the clay sank. The lime has for some

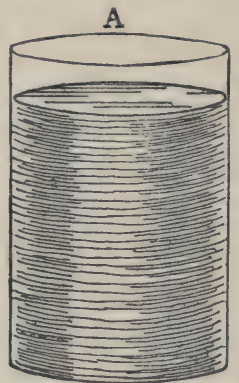

No lime added

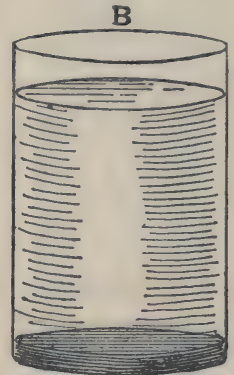

Lime added

Fig. 10.

Addition of lime to turbid clay water now makes the clay settle and leaves the water quite clear

reason or other, which we do not understand, made the small clay particles stick together to form the large flocks, and these can no longer float, but sink. If we look at the limed clay in our funnel experiment we shall see that the same change has gone on there; the clay has become rather loose and fluffy, and can therefore no longer hold water back.

Lime also makes clay less sticky. Knead up one piece of clay with rain water alone and another piece 
with rain water and about $\frac{2}{2}$ its weight of lime. The limed clay breaks easily and works quite differently from the pure clay.

Summary. This, then, is what we have learnt about clay. Clay is made up of very, very, tiny pieces, so small that they float in water. They stick together when they are wetted and then pressed, and they remain together; a piece of clay moulded into any pattern will keep its shape even after it is dried and baked. Clay is therefore made into bricks, earthenware, pottery, etc., whilst white clay, which is found in some places, is made into china. Wet clay shrinks and cracks as it dries; these cracks can easily be seen in the fields during dry weather. This shrinkage interferes with the foundations of houses and other buildings, causing them to settle. Dry clay is different from wet clay, it is hard, not sticky and not slippery, but it at once becomes like ordinary clay when water is added. After baking, however, clay permanently alters and cannot again be changed back to what it was before. Clay will not let water pass through; a clay field is therefore nearly always wet in winter and spring. Nor can air pass through until the clay dries or cracks.

Lime has a remarkable action on clay. It makes the little, tiny pieces stick together to form feathery flocks which sink in water; lime therefore causes muddy clay water to become clear. The flocks cannot hold water back, and hence limed clay allows water to pass through. Limed clay is also less sticky than pure clay. A clay field or garden is improved by adding lime because the soil does not remain wet so long as it did before; it is also less sticky and therefore more easily cultivated. 


\section{CHAP'IER IV}

SOME EXPERIMENTS WITH THE SAND

\section{Apparatus required.}

Sand, about 6 lbs. ; clay, about 6 lbs. Six funnels, stands and dislis [1]. Six glass jars [2]. One box with glass front shown in Fig. 13 filled with clay and sand as indicated. Quarry chalk (about 5 lbs.). Six beakers [1]. Six egg-cups [1].

If there is a sand pit near you, or a field of sandy soil, you should get a supply for these experiments; if not, some builder's sand can be used. When the sand is dry you will see that the grains are large and hard. Further, they are all separate and do not stick together; if you make a hole in a heap of the sand, the sides fall in, there is nothing solid about it, and you can easily see the mistake of the foolish man who built his house upon the sand. When the sand is wet it sticks better and can be made into a good many things; at the seaside you can make a really fine castle with wet sand. But as soon as the sand dries it again becomes loose and begins to fall to pieces.

Strong winds will blow these fragments of dry sand about and pile them up into the sand hills or dunes common in many seaside districts (Fig. 11). Blowing sands can also be found in inland districts; in the northern part of Surrey, in parts of Norfolk and many 


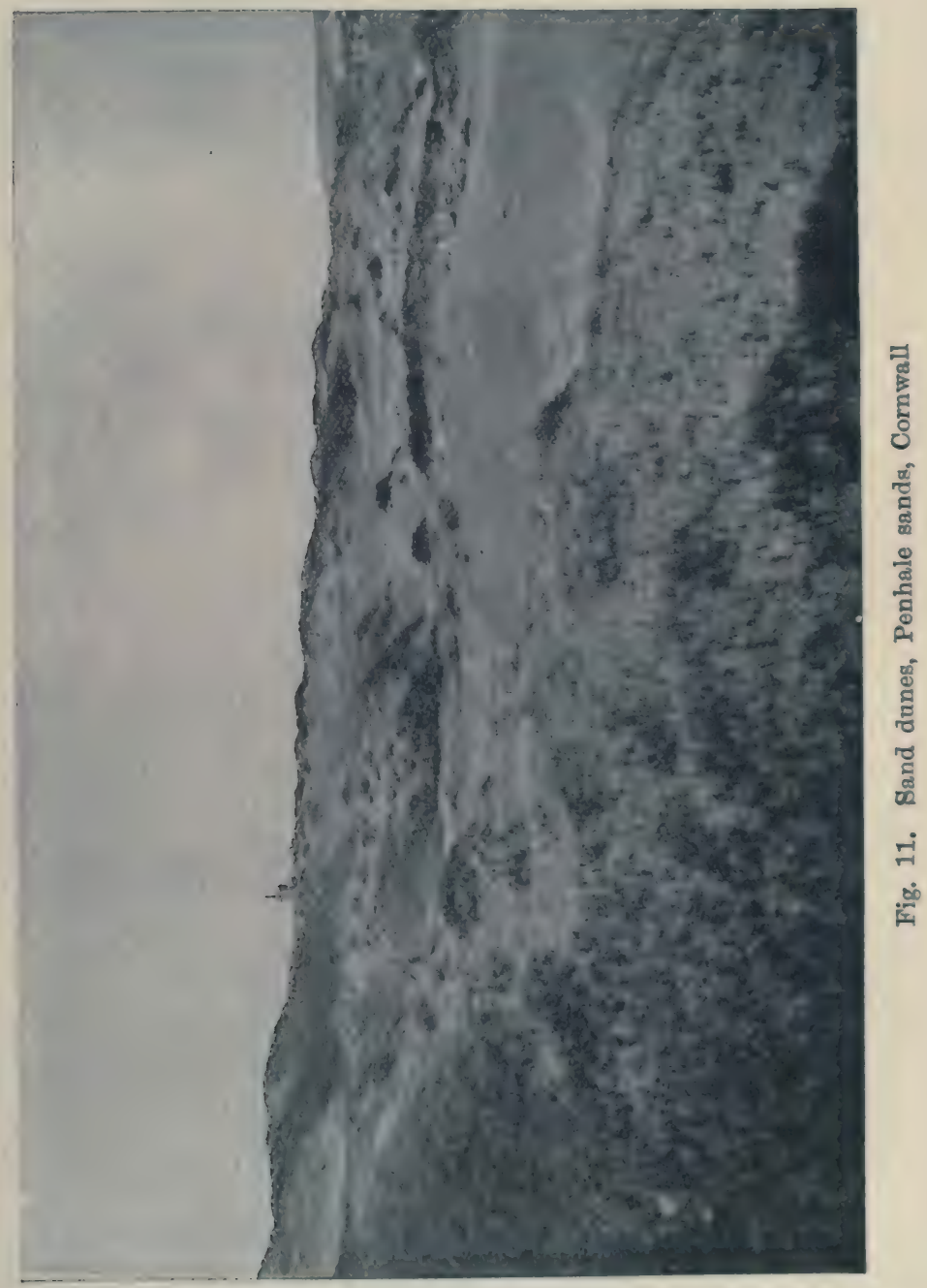


other places are fields where so much of the soil is blown away by strong winds that the crops may suffer injury. In Central Asia sand storms do very much harm and have in the course of years buried entire cities. Fig. 12 shows the Penhale sands in Cornwall gradually covering up some meadows and ruining them.

Sand particles, being large, do not float in water. If we shake up sand in water the sand sinks, leaving the water entirely clear. So running water does not carry sand with it unless it is running very quickly: the sand lies at the bottom.

Unlike clay, sand does not hold water. Pour some water on to sand placed on the tin disk in a funnel (Fig. 8); it nearly all runs through at once. We should therefore expect a sandy field or a sandy road to dry up very quickly after rain and not to remain wet like a clay field. So much is this the case that people prefer to live on a sandy soil rather than on a clay. The most desirable residential districts round London, Hampstead on the north, and the stretch running from Haslemere on the south-west to Maidstone on the south-east, and other favoured regions, are all high up on the sand.

At the foot of a hill formed of sand you often find a spring, especially if clay or solid rock lies below. It is easy to make a model that will show why the spring forms at this particular place. Fill the lower part of the box shown in Fig. 13 with wet clay, smoothing it out so that it touches all three sides and the glass front; then on top of the clay put enough sand to fill the box. Bore four holes in the side as shown in the picture, one at the bottom, one at the top, one just above the junction of the sand and clay, the fourth half way up the sand, and fix in glass tubes with clay or putty. Pour 


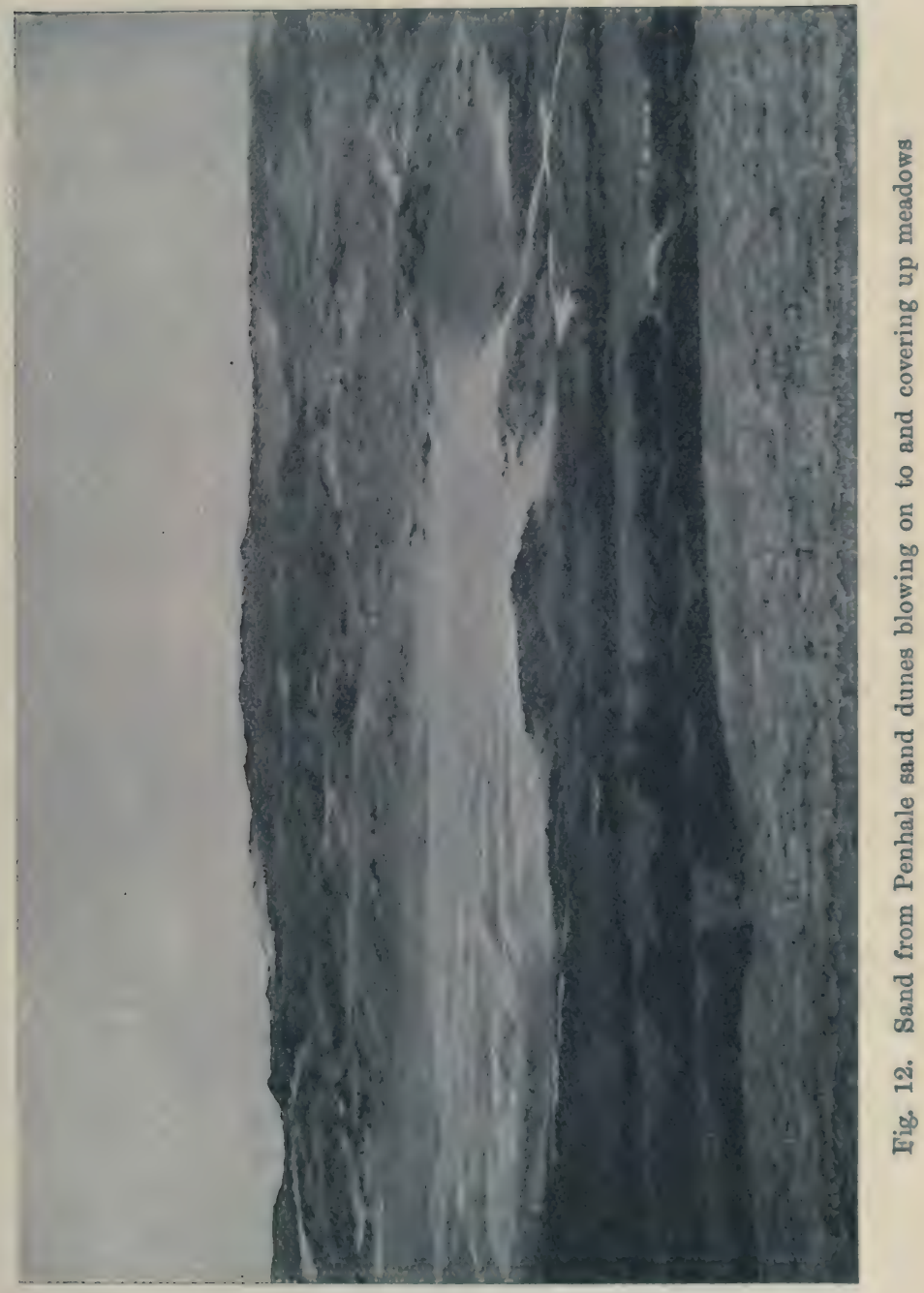


water on to the sand out of a watering can fitted with the rose so as to imitate the rain. At first nothing seems to happen, but if you look closely you will notice that the water soaks through and does not lie on the surface; it runs right down to the clay; then it comes out at the tube there ( $c$ in the picture). None goes through the clay, nor does enough stay in the sand to flow out through either the top or the second tube ; of the four tubes only one is discharging any water. The discharge does not stop when the supply of water stops. The rain need only fall at intervals, but the water will flow all the time.

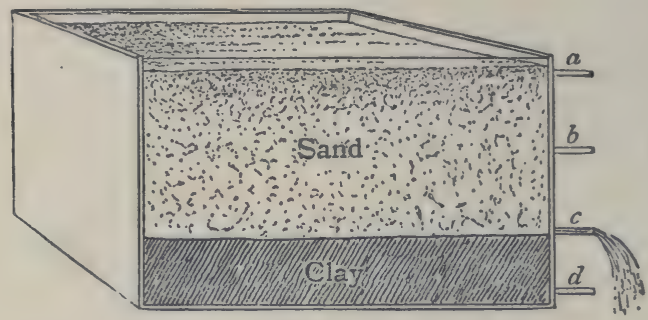

Fig. 13.

Model spring. A box with glass front contains a layer of clay and one of sand. Water that falls on the sand runs right down to the clay but can get no further, and therefore flows out through the tube $c$ at the junction of the clay and the sand. The same result

is obtained when chalk takes the place of sand

The experiment should now be tried with some chalk from a quarry; it gives the same results and shows that chalk, like sand, allows water readily to pass.

Just the same thing happens out of doors in a sandy or chalky country; the rain water soaks through the sand or chalk until it comes to clay or solid rock that it cannot pass, then it stops. If it can find a way out it 


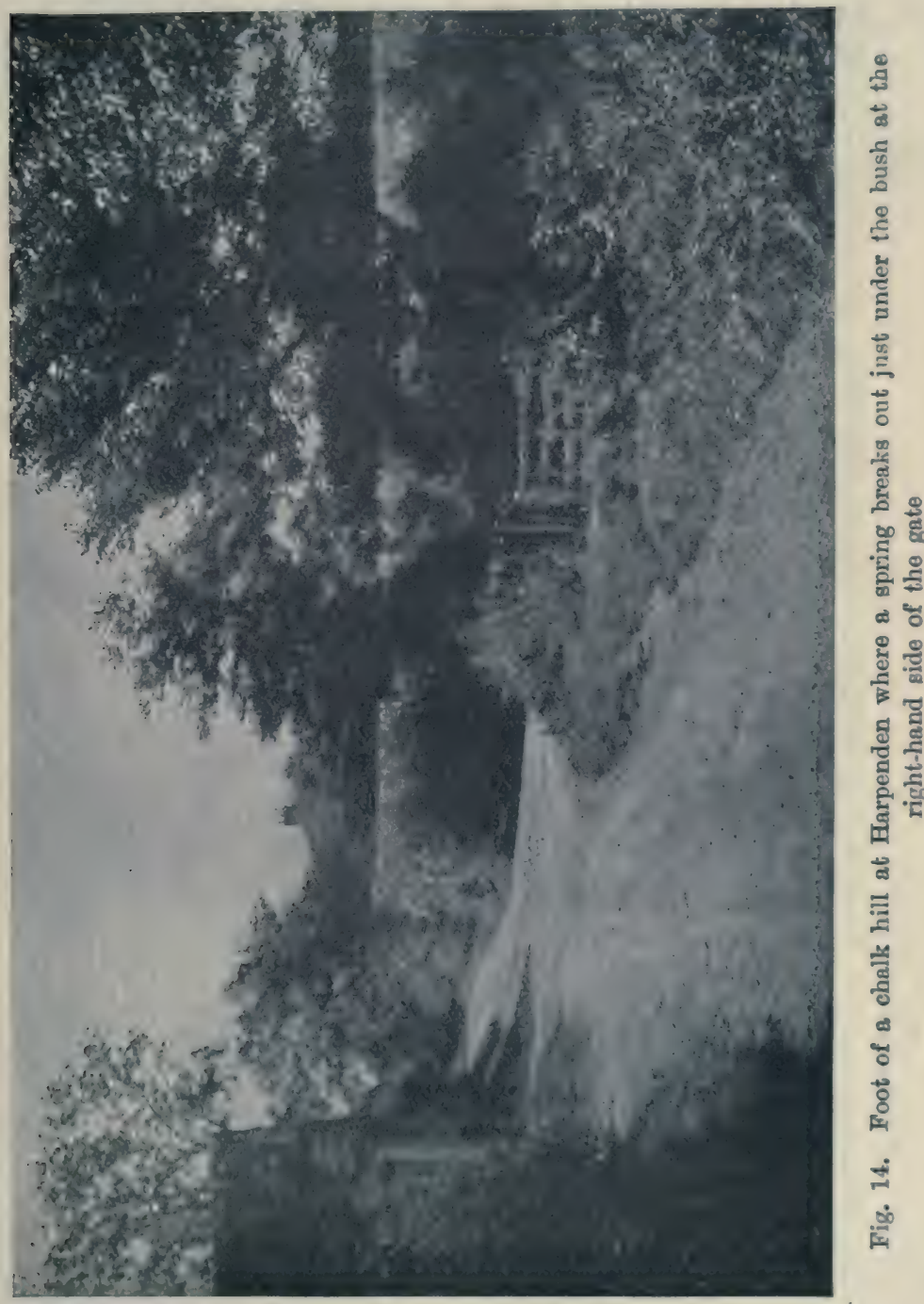


does so and makes a spring, or sometimes a whole line of springs or wet ground. Rushes, which flourish in such wet places, will often be found growing along this line, and may, indeed, in summer time be all you can see, the water having drained away. But after much rain the line again becomes very wet. Fig. 14 shows the foot of a chalk hill near Harpenden, where a spring breaks out just under the bush at the right-hand side

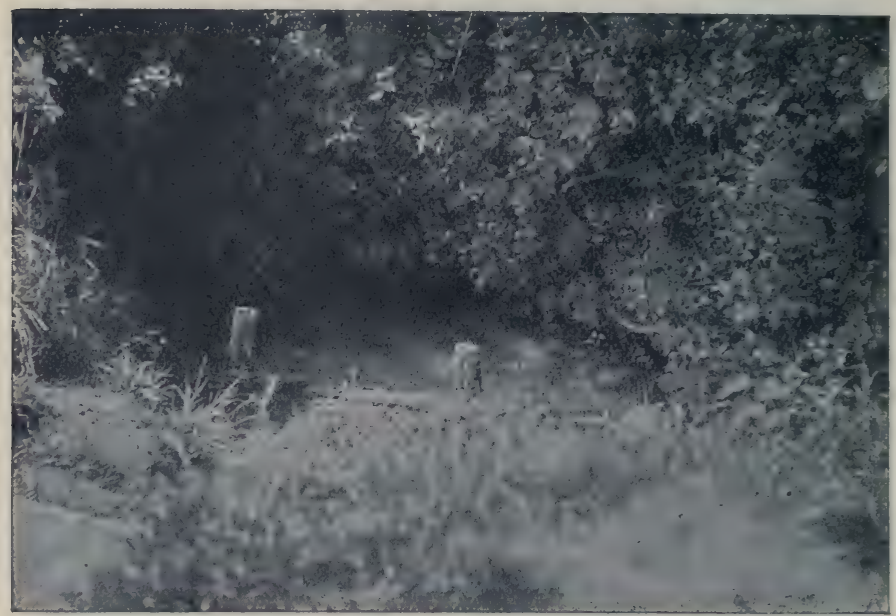

Fig. 15. "The little pool below the tree"

of the gate. In Fig. 15 the bush itself is seen, with the little pool of water made by the spring. Here the water flows gently, but elsewhere it sometimes happens, as in Fig. 16, that the spring breaks out with great force.

Now stop up the glass tubes so that the water cannot get out. Soon the sand becomes flooded and is no better than clay would be. A second model will show this very well. Make a large saucer of clay and fill with sand: 


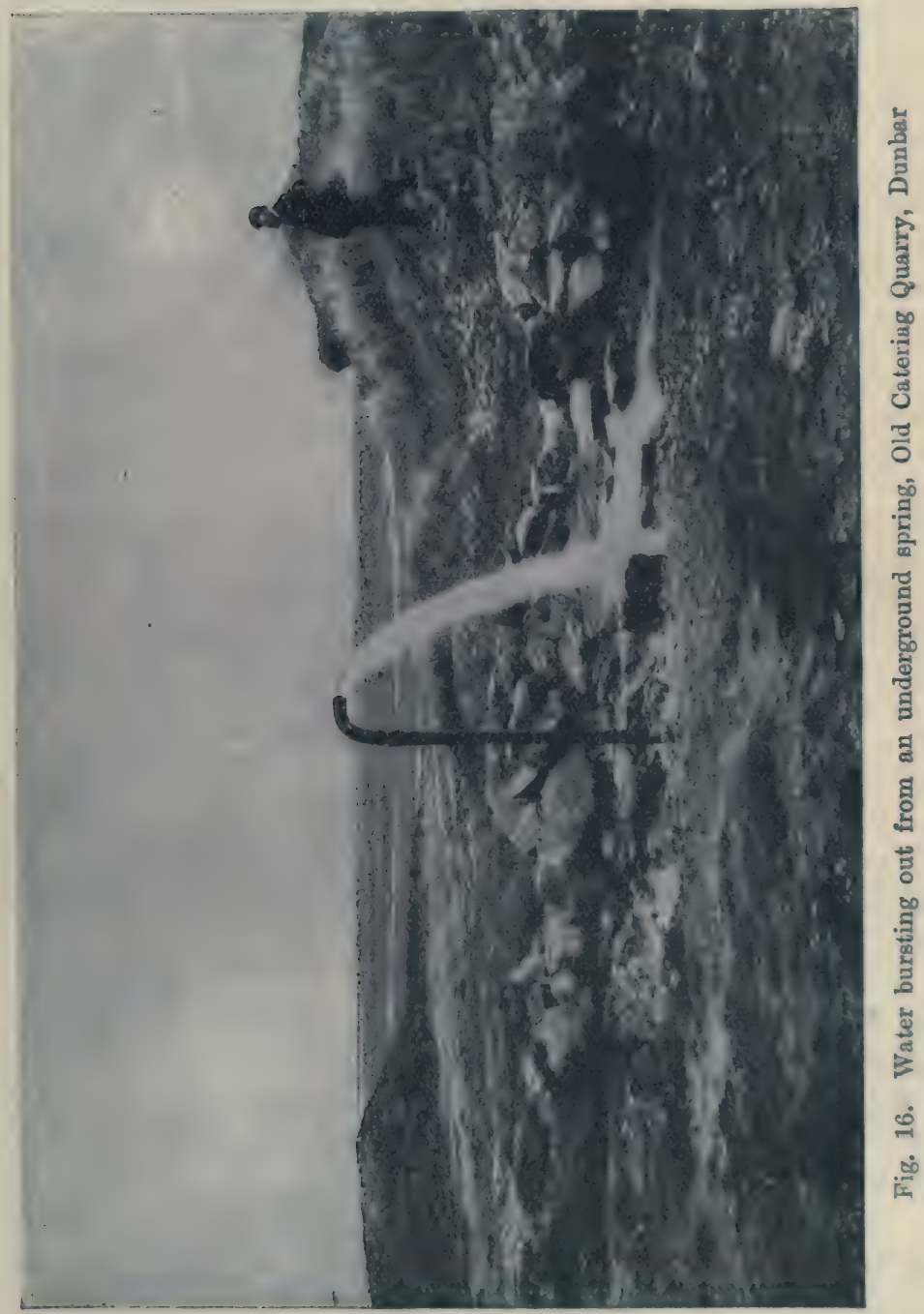


pour water on. The water stays in the sand, because it cannot pass through the clay. A sandy field saturated like this will therefore not be dry, but wet, and will not make a good position for a house. We must therefore distinguish the two cases illustrated in Fig. 17. A shows sand on a hill, dry because the water runs through until it comes to clay or rock, when it stops and breaks out as a spring, a tiny stream, or pond; this is a good building site and you may expect to find large houses there. $B$ shows the sand in a basin of clay, where the water cannot get away: here the cellars and downstairs rooms are liable to be wet, and in a village the wells give impure water. Matters could be improved if a way out were cut for the water, but then the foundations of the buildings might move a little.

It often happens that villages are situated at the junction of sand and clay, or chalk and clay, because the springs furnish forth a good water supply.

On the other hand large tracts of clay which remain wet and sticky during a good part of the year are not very attractive to live in, and even near London they were the last to be populated: Hither Green in the south-east and the clay districts of the north-west have only of late years been built on; while the sands and gravels of Highgate, Chiswick, Brentford and other places had long been occupied. Elsewhere, villages on the clay do not grow quickly unless there is much manufacturing or mining; the parishes are large, the roads even now are not good while they used to be very bad indeed. Macaulay tells us that at the end of the seventeenth century in some parts of Kent and Sussex "none but the strongest horses could in winter get through the bog, in which at every step they sank 
deep. The markets were often inaccessible during several months....The wheeled carriages were, in this district, generally pulled by oxen. When Prince George of Denmark visited the stately mansion of Petworth in wet weather, he was six hours in going nine miles; and it was necessary that a body of sturdy hinds should be on each side of his coach to prop it up. Of the carriages which conveyed his retinue several were upset and injured. A letter from one of the party has been preserved in which the unfortunate courier complains that, during fourteen hours, he never once alighted, except when his coach was overturned or stuck fast in the mud." The Romans knew how to make roads anywhere, and so they

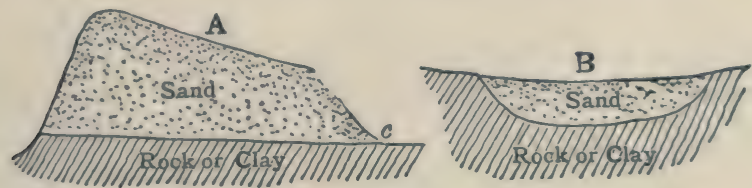

Fig. 17.

Two positions of sand. $A$ is dry because the water can drain away and break out as a spring at $c$. $B$ is wet because the water cannot drain away

made them run in a straight line between the two places they wished to connect, but the art was lost in later years, and the country roads made in England since their time usually had to follow the sand or the chalk, avoiding the clay as much as possible. These roads we still use. Fig. 18 shows the roads round Wye; you should in your rambles study your own roads and see what soil they are on.

There are several other ways in which sand differs from clay. It does not shrink on drying nor does it 
swell on wetting, and you will find nothing happens when you try with sand the experiment with the model field (p. 11) or the egg-cup (p. 12).

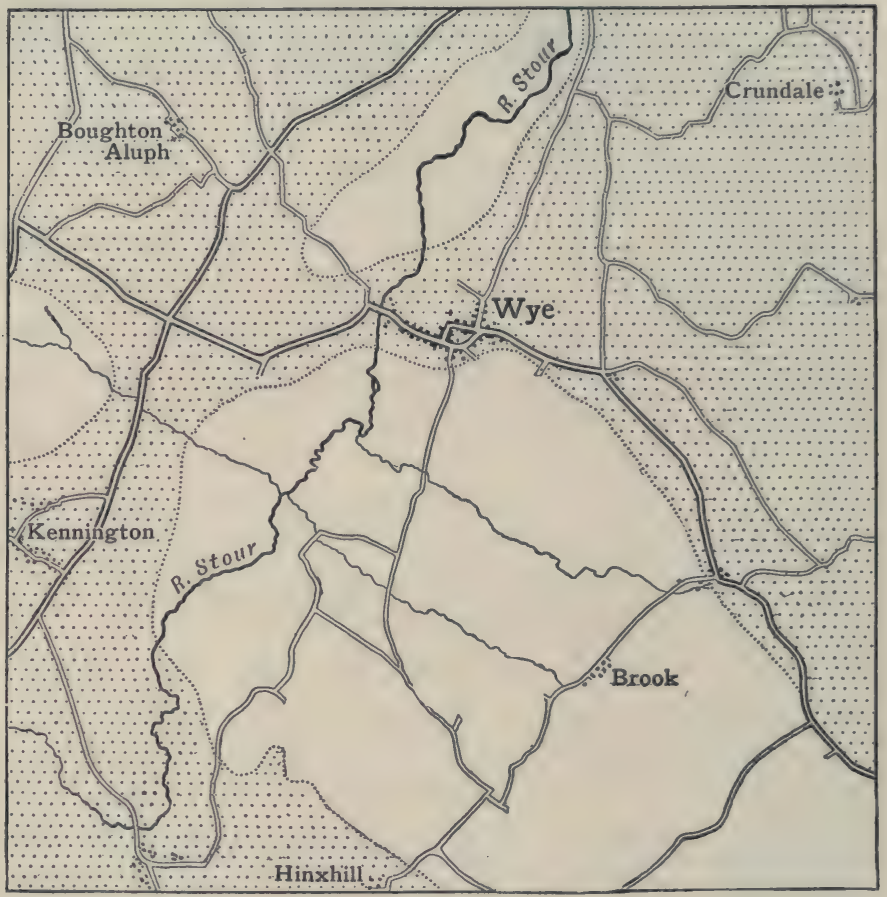

Fig. 18.

The roads round Wye. As far as possible they keep off the clay (the plain part of the map) and keep on the chalk or the sand (the dotted part of the map) 


\section{CHAPTER V}

\section{THE PART THAT BURNS AWAY}

\section{Apparatus required.}

Leaf mould. Mould from a tree. Peat. About $1 \mathrm{lb}$. soil from a wood, a well-manured garden and a field; also some subsoil. Six crucibles or tin lids. Six tripods, pipe-clay triangles, and bunsen burners or spirit lamps. Six beakers and egg-cups [1].

In the autumn leaves fall off the trees and form a thick layer in the woods. They do not last very long; if they did they would in a few years almost bury the wood. You can, in the springtime or early summer find out what has happened to them if you go into a wood or carefully search under a big hedge in a lane where the leaves were not swept away. Here and there you come across skeleton leaves where only the veins are left, all the rest having disappeared. But generally where the leaves have kept moist they have changed to a dark brown mass which still shows some of the structure of a leaf. This is called leaf mould. The top layer of soil in the wood is soft, dark in colour, and is evidently leaf mould mixed with sand or soil.

Leaf mould is highly prized by gardeners, indeed gardeners will often make a big heap of leaves in autumn and let them "rot down" and change into mould. If you can in autumn collect enough leaves to make a heap you 
should do so and leave it somewhere where the rain can fall on it, but cover it with a few small branches of trees to prevent the wind blowing the leaves away. The heap shrinks a great deal during the first few months, and in the end it gives a supply of mould that will be very useful if you want to grow any plants in pots.

Some of the little hollows in the bank under a hedge, especially on chalky soils, are filled with leaf mould which has sometimes changed to a black powder not looking at all like leaves.

You can also find mould in holes in decayed trees; here it has formed from the wood of the tree.

It appears, then, that dead leaves, etc., slowly change into a black or brown substance, shrinking very much as they do so. For this reason they do not go on piling up year after year till finally they fill the wood; instead they decay or "rot down" to form leaf mould: the big pile of the autumn has changed by the next summer to a thin layer which mixes with the soil.

We want now to see what happens on a common or a piece of waste ground that is not cultivated. Grass and wild plants grow up in summer and die during winter; their stems and roots are not taken away, but clearly they do not remain where they are, because next year new plants grow up. We may suppose that the dead roots and stems decay like the leaves did, and change to a brown or black mould. It looks as if we are right, because on digging a hole or examining the side of a freshly cut ditch we shall find that the top layer of soil, just so far as the living roots go, is darker in colour than the layer below.

We must, however, try and get some more proof, and to do this we must study some of our specimens a little 
more closely. We will take some leaf mould, some black mould from a hollow in the bank, some from a tree, soils from a wood, a well-manured garden, a field and some subsoil. All except the subsoil have a dark colour, but the wood and garden soils are probably darker than the field soil. Now weigh out 2 grams of each of these and heat in a dish as you did the soil on p. 4 ; notice that all except the subsoil go black and then begin to smoulder, but the moulds smoulder more than the soils. Then weigh again and calculate how much has burnt away in each case. Here are some results that have been obtained at Harpenden :-

\begin{tabular}{|c|c|c|c|c|}
\hline & $\begin{array}{c}\text { Colour before } \\
\text { burning }\end{array}$ & $\begin{array}{c}\text { Amount } \\
\text { of } \\
\text { smoulder- } \\
\text { ing }\end{array}$ & $\begin{array}{c}\text { Percentage } \\
\text { loss on } \\
\text { burning }\end{array}$ & $\begin{array}{l}\text { Colour of } \\
\text { residue }\end{array}$ \\
\hline Leaf mould...... & dark brown & much & $78 \cdot 3$ & light grey \\
\hline $\left.\begin{array}{l}\text { Mould from } \\
\text { dead tree }\end{array}\right\}$ & black & much & $60 \cdot 6$ & light grey \\
\hline Soil from wood & dark brown & less & $43 \cdot 4^{1}$ & white \\
\hline Soil from garden & almost black & less & $10 \cdot 1$ & red \\
\hline Soil from field & brownish & still less & $5 \cdot 4$ & red \\
\hline Subsoil............. & red & none & $2 \cdot 0$ & red \\
\hline
\end{tabular}

The mould nearly all burns away and its dark colour entirely goes, so also does the dark colour of the soil.

Our supposition explains why, in the case of soils, the less the blackness, the less the loss on burning. If the

1 The top two inches of soil only were colleoted here, and there were many leaves, twigs, etc. mixed in. Soils from different woods vary considerably. If the sample is taken to a greater depth the loss on burning is much less, and may be only 5 or 6 per cent. 
brown or black combustible part is really mould formed by the decay of plant roots, etc., then we should expect that as the percentage of mould in the soil increased, so its blackness would increase and its loss on burning would become greater. This actually happens.

This, then, is our idea. We suppose that the plants that have lived in past years have decayed to form a black material like leaf mould which stops in the soil, giving it a darkish colour. The more mould there is, the darker the colour of the soil. We know that along with this decay there is a great deal of shrinkage. As the black material is formed from the plant, it only extends as far into the soil as the plant roots go, so that there is a sharp change in colour about 6 inches below the surface (see also p. 2). Like the plant the black material all burns away when the soil is heated sufficiently.

Thus we can explain all the facts we have observed, and in what seems a very likely way. This does not show that our supposition is correct, but only that it is useful. When you come to study science subjects you will find such suppositions, or hypotheses as they are called, are frequently used so long as they are found to be helpful. In our present case we could only get absolute proof that the black combustible part of the soil really arose from the decay of plants by watching the process of soil formation. We shall turn later to this subject.

The black material is known as humus. Farmers and gardeners like a black soil containing a good deal of humus because they find it very rich, and we shall see later on why this is so. Vast areas of such soils occurring in Manitoba, in Russia, and in Hungary are used for 
wheat growing, while there are also areas in the Fen districts of England.

There is something known as peat that looks rather like mould, but is really so different that you must be careful not to confuse the two. Peat is not good for plants, and does not make the soil fertile; but quite the reverse. You can see it being formed on a moor or bog, and you should at the first opportunity go and examine it. There was a peat bog near Wye that was examined with the following results. The peat was very fibrous and had evidently been formed from plants. It made a layer about 2 feet thick and underneath it was a bed of clay; this was discovered by examining the ditches, some of which cut right through the peat into the clay below. A sample of the clay put into a funnel, as on p. 14, did not allow water to pass through; this was also evident from the very wet nature of the ground. The peat bed was below the level of the surrounding land and was in a sort of basin; the water draining from the higher land could all collect there but could not run away, indeed it might very well have been a shallow lake. It was quite clear that the plants as they died would decay in very wet soil, and so the conditions are very different from those we have just been studying where the plants decay in soil that is only moist. This difference at once shows itself in the fact that peat generally forms a thick layer, while mould only rarely does so. In the north of England the moors lie high, but here again the peat bed is like a saucer or basin, and there is soil or rock below that does not let the rain water pass through. For a great part of the year the beds are very wet. 
Look at a piece of peat and notice how very fibrous it is, quite unlike leaf mould. When it is dry peat easily burns and is much used as fuel in parts of Scotland, Wales and Ireland. It is cut in blocks during the spring, left to dry in heaps during summer, and then carried away in autumn. Fig. 19 shows a peat bog with cutting going on. Peat does not easily catch light and the fires are generally kept burning all night; there is no great flame such as you get with a coal fire, but still there is quite a nice heat.

Peat has a remarkable power of absorbing water. Fill an egg-cup with peat, packing it as tightly as you possibly can, and then put it under water and leave for some days. The peat becomes very wet and swells considerably, overflowing the cup just like the clay did on p. 12. After long and heavy rains peat in bogs swells up so much that it may become dangerous; if the bog is on the side of a hill, the peat may overflow and run down the hill like a river, carrying everything before it. Such overflows sometimes occur in Ireland and they used to occur in the north of England; you can read about one on Pendle Hill in Harrison Ainsworth's Lancashire Witches. But they do not take place when ditches are cut in the bog so that the water can flow away instead of soaking in ; this has been done in England.

This great power of absorbing water and other liquids, so terrible when it leads to overflows, enables peat to be put to various uses, and a good deal of it is sold as peat-moss, for use in stables.

In the ditches of a peat bog red slimy masses can often be found. They look just like rusty iron, and in fact they do contain a good deal of iron, but there are also a number of tiny little living things present. The 


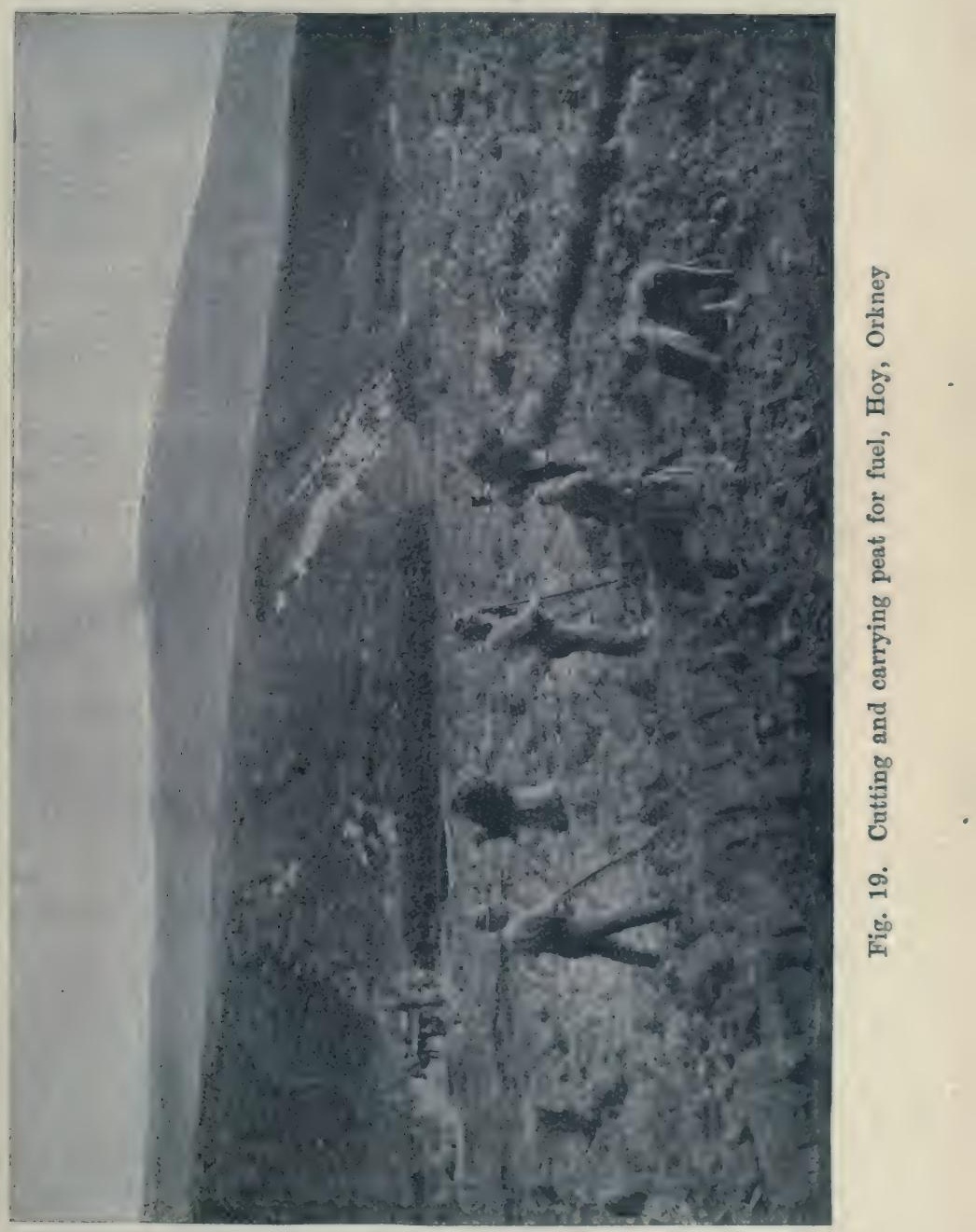


stones and grit just under the peat are usually white, all the red material from them having been washed out by the water which has soaked through the peat. Then at the ditch these tiny living things take up the red material because it is useful to them. Peat or "moorland" water can also dissolve lead from lead pipes and may therefore be dangerous for drinking purposes unless it is specially purified. When you study chemistry you will be able to show that both peat itself and moorland waters are "acid" while good mould is not. That is why peat is not good for cultivated plants (see also p. 96).

Other things besides peat are formed when plants decay under water. If you stir up the bottom of a stagnant pond with a stick bubbles of gas rise to the surface and will burn if a lighted match is put to them. This gas is called marsh gas. Very unpleasant and unwholesome gases are also formed. 


\section{CHAPTER VI}

\section{THE PLANT FOOD IN THE SOIL}

\section{Apparatus required.}

The pot experiments ( $p$. xiii).

It is a rare sight in England to see land in a natural uncultivated state devoid of vegetation. The hills are covered with grasses and bushes, the moors with ling and heather, commons with grass, bracken and gorse, a garden tends to become smothered in weeds, and even a gravel path will not long remain free from grass. It is clear that soil is well suited for the growth of plants. We will make a few experiments to see what we can find out about this property of soil.

We have seen that a good deal of the soil is sand or grit, and we shall want to know whether this, like soil, can support plant life. We have also found that the subsoil is unlike the top soil in several ways, and so we shall want to see how it behaves towards plants. Fill a pot with soil taken from the top nine inches of an arable field or untrenched part of the garden; another with subsoil taken from the lower depth, 9 to 18 inches, and a third with clean builder's sand or washed seasand. Sow with rye or mustard, and thin out when the seeds are up. Keep the pots together and equally well supplied with water; the plants then have as good a chance of growth in oue pot as in any other. 


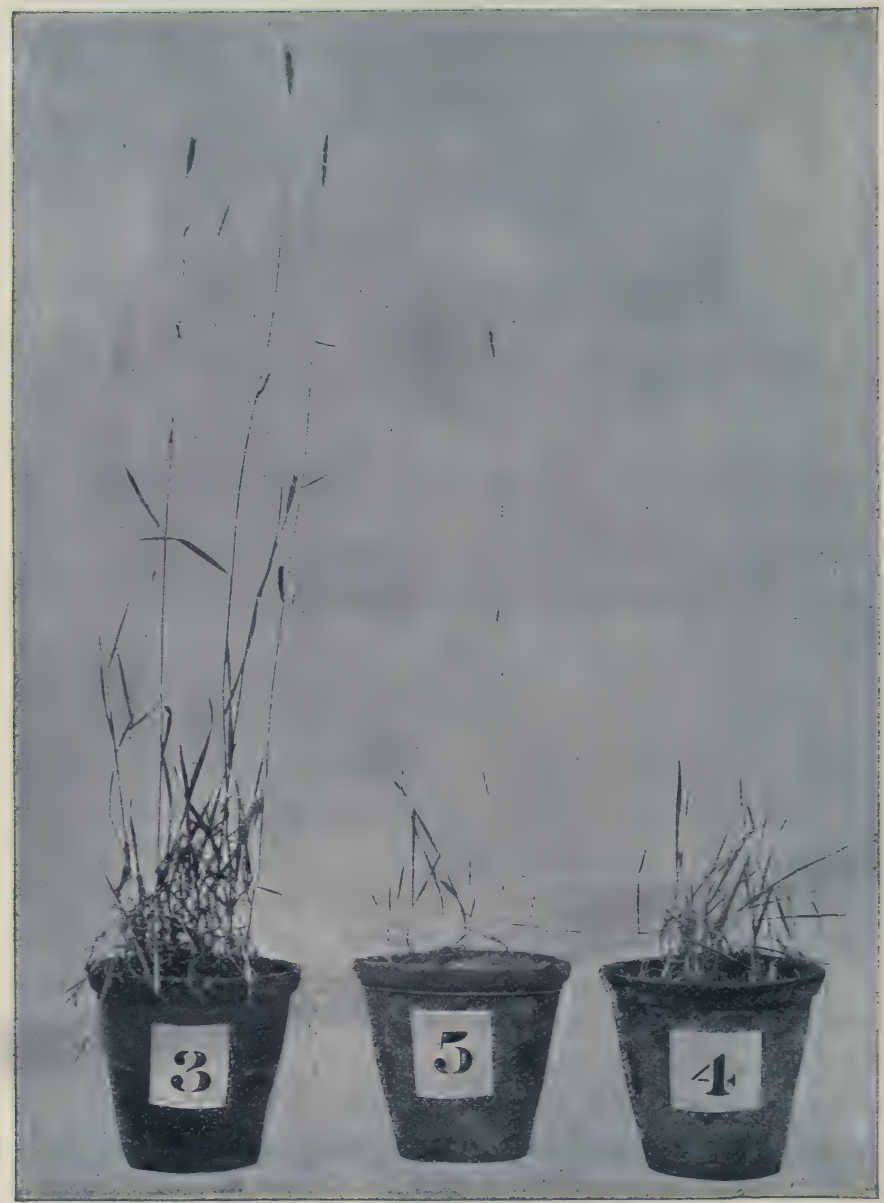

Fig. 20.

Rye growing in surface soil (Pot 3), subsoil (Pot 4), and sand (Pot 5) 
Figs. 20 and 21 are photographs of sets of plants grown in this way; the weights in grams were:-

\begin{tabular}{|c|c|c|c|c|c|c|}
\hline & & & \multicolumn{2}{|c|}{ Green weight } & \multicolumn{2}{|c|}{ After drying } \\
\hline & & & Rye & Mustard & Rye & Mustard \\
\hline \multicolumn{3}{|c|}{ Plants grown in top soil (Pot 3 ) } & 14.5 & $17 \cdot 7$ & $5 \cdot 6$ & $2 \cdot 6$ \\
\hline$"$ & $n$ & subsoil (Pot 4) & $2 \cdot 9$ & $5 \cdot 1$ & $1 \cdot 6$ & $1 \cdot 1$ \\
\hline " & " & sand $($ Pot 5)... & $2 \cdot 0$ & $4 \cdot 6$ & 0.8 & 10 \\
\hline
\end{tabular}

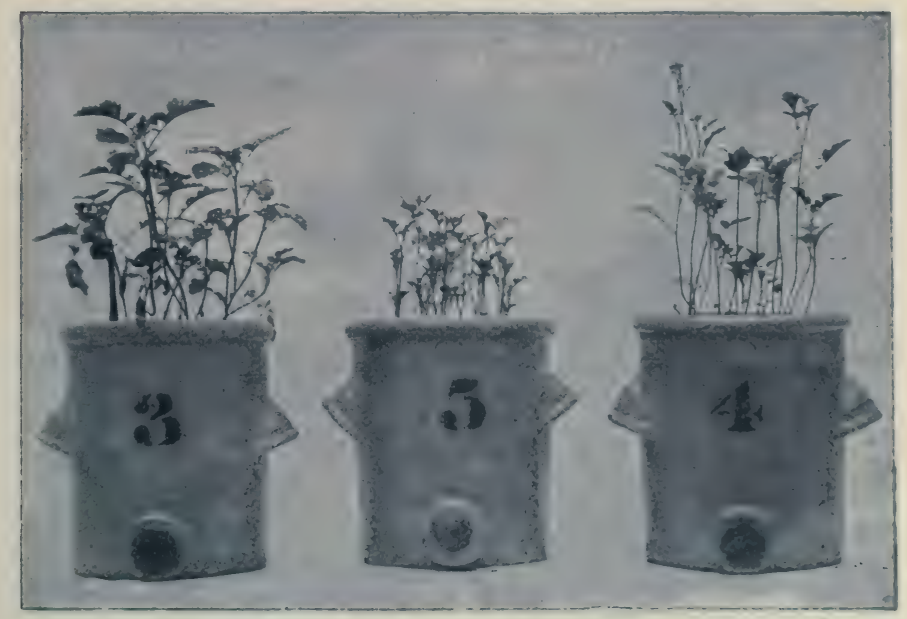

Fig. 21.

Mustard growing in surface soil (Pot 3), subsoil (Pot 4), sand (Pot 5)

The plants in the soil remained green and made steady growth. Those in the sand never showed any signs of getting on, their leaves turned yellow and 
fell off; in spite of the care they received, and the water, warmth and air given them, they looked starved, and that, in fact, is what they really were. Nor did those in the subsoil fare much better. The experiment shows that the top soil gives the plant something that it wants for growth and that it cannot get either from sand or from the subsoil; this something we will call "plant food."

Further proof is easily obtained. At a clay or gravel pit little or no vegetation is to be seen on the sloping sides or on the level at the bottom, although the surface soll is carrying plants that shed innumerable seeds. A heap of subsoil thrown up from a newly made well, or the excavations of a house, lies bare for a long time. The practical man has long since discovered these facts. A gardener is most particular to keep the top soil on the top, and not to bury it, when he is trenching. In levelling a piece of ground for a cricket pitch or tennis court, it is not enough to lift the turf and make a level surface; the work has to be done so that at every point there is sufficient depth of top soil in which the grass roots may grow.

How much plant food is there in the top soil? To answer this question we must compare soil that has been cropped with soil that has been kept fallow, i.e. moist but uncropped. Tip out some of the soil that has been cropped with rye, and examine it. Remove the rye roots, then replace the soil in the pot and sow with mustard; sow also a fallow pot with mustard. Keep both pots properly watered. The soil that has carried a crop is soon seen to be much the poorer of the two. Fig. 22 shows the plants, while their weights in grams were:- 


\begin{tabular}{|l|c|c|}
\hline & Green weight & After drying \\
\cline { 1 - 3 } $\begin{array}{c}\text { Mustard growing in soil previously } \\
\text { cropped with rye, Pot 1 } \\
\begin{array}{c}\text { Mustard growing in soil previously ? } \\
\text { uncropped, Pot 2 }\end{array}\end{array}$ & $17 \cdot 8$ & $3 \cdot 3$ \\
\hline
\end{tabular}

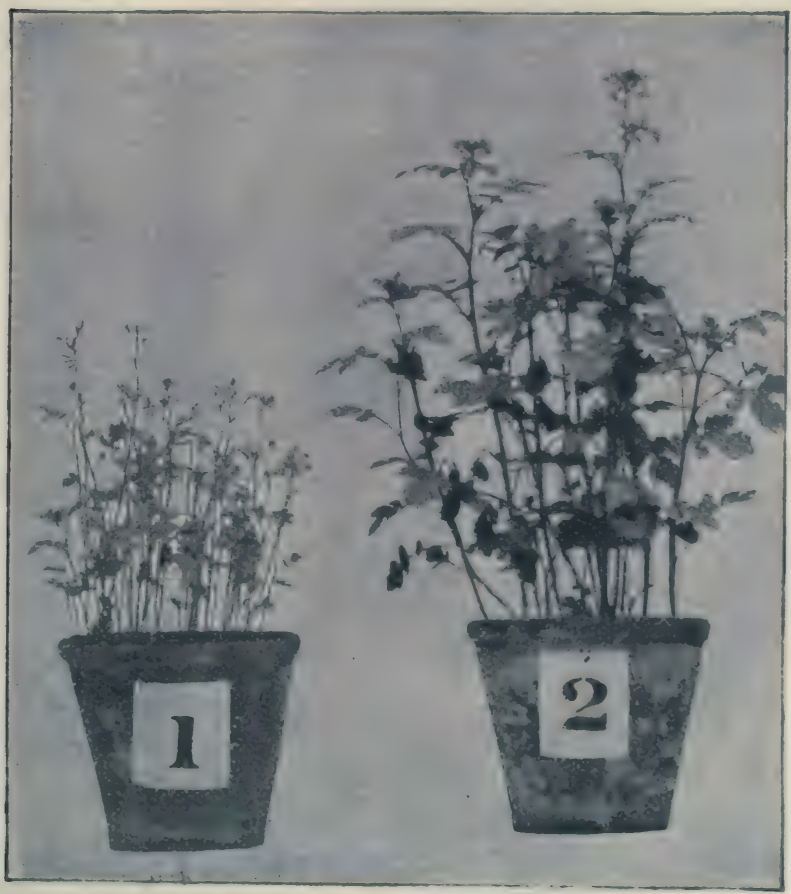

Fig. 22.

Mustard growing in surface soil previously oropped with ryo (Pot 1) and in surface soll previously unoropped (Pot \&) 
The rye has taken most of the plant food that was in Pot 1 leaving very little for the second crop. Our soil therefore contained only a little plant food, not more, in fact, than will properly feed one crop. But yet it did not seem to have altered in any way, even in weight, in consequence of the plant food being taken out. In our experiment the soil was dried and weighed before and after the mustard was grown; the results were :-

$$
\begin{aligned}
& \text { Pot } 2 \text { Pot } 2 a \\
& \text { lbs. oz. lbs. oz. } \\
& \text { Weight of dried soil before the experiment... } 6 \begin{array}{llll}
6 & 6 & 6 & 7
\end{array}
\end{aligned}
$$

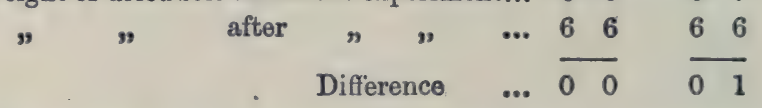

The experiment is not good enough to tell us exactly how much plant food was present at the beginning. But we can say that the amount of plant food in the soil is too small to be detected by such weighing as we can do.

Here is an account of a similar experiment made 300 years ago by van Helmont in Brussels, and it is interesting because it is one of the first scientific experiments on plant growth:-

"I took an earthen vessel in which I put 200 pounds of soil dried in an oven, then I moistened with rain water and pressed hard into it a shoot of willow weighing 5 pounds. After exactly five years the tree that had grown up weighed 169 pounds and about 3 ounces. But the vessel had never received anything but rain water or distilled water to moisten the soil (when this was necessary), and it remained full of soil which was siill tightly packed, and lest any dust from outside should have got into the soil it was covered with a sheet 
of iron coated with tin but perforated with many holes. I did not take the weight of the leaves that fell in the autumn. In the end I dried the soil once more, and got the same 200 pounds that I started with, less about two ounces. Therefore the 164 pounds of wood, bark and root arose from the water alone." The experiment is wonderfully good and shows how very little plant food there is in the soil. The conclusion is not quite right, however, although it was for many years accepted as proof of an ancient belief, which you will find mentioned in Kingsley's Westward Ho!, that all things arose from water. It is now known that the last sentence should read, "Therefore the 164 pounds of wood, bark and root arose chiefly from the water and air, but a small part came from the soil also."

But to return to our experiment with Pots 1 and 2. They had been kept moist before the mustard was sown. Did this moisture have any effect on the soil? Take two of the pots that have been kept dry and uncropped, and two that have been kept moist and uncropped, also one of dry uncropped subsoil and one of moist uncropped subsoil. Sow rye or mustard in each pot and keep them all equally supplied with water.

It is soon evident that the top soil is richer in plant food than the subsoil, and the soil stored moist is rather richer than that stored dry, although the difference here is less marked. In an experiment in which the soils were put up early in July and sown at the end of September the weights of crops in grams obtained were:- 


\begin{tabular}{|c|c|c|}
\hline & Green weight & After drying \\
\hline $\left.\begin{array}{l}\text { Plants grown in top soil stored in } \\
\text { moist condition (Pots } 10 \& 11)\end{array}\right\}$ & $\begin{array}{l}16 \cdot 9 \\
18 \cdot 9\end{array}$ & $\begin{array}{l}2 \cdot 6 \\
2 \cdot 8\end{array}$ \\
\hline $\begin{array}{l}\text { Plants grown in top soil stored in } \\
\text { dry condition (Pots } 8 \& 9 \text { ) }\end{array}$ & $\begin{array}{l}12 \cdot 1 \\
14 \cdot 4\end{array}$ & $\begin{array}{l}1 \cdot 8 \\
1 \cdot 9\end{array}$ \\
\hline $\left.\begin{array}{l}\text { Plants grown in subsoil stored in } \\
\text { moist condition (Pot 13) }\end{array}\right\}$ & $5 \cdot 5$ & 0.9 \\
\hline $\begin{array}{l}\text { Plants grown in subsoil stored in } \\
\text { dry condition (Pot 12) }\end{array}$ & $5 \cdot 6$ & 0.8 \\
\hline
\end{tabular}

The crops on Pots 10 and 11 ought of course to weigh the same, and so should the crops on Pots 8 and 9. The differences arise from the error of the experiment. In all experimental work, however carefully carried out or however skilful the operator, there is some error.

There is clearly an increase in crop as a result of storing the surface soil in a moist condition, showing that additional plant food has been made since these pots were put up. On the other hand it does not appear that much plant food has been made in the subsoil during this time. Further evidence on this point is given by an experiment similar to that in Fig. 22, but where mustard is grown in subsoil kept moist, but uncropped for some time, and in subsoil previously cropped with rye. The results in grams were:-

\begin{tabular}{|c|c|c|}
\hline & Green weight & After drying \\
\cline { 1 - 2 } $\begin{array}{c}\text { Mustard growing in subsoil pre- } \\
\text { viously cropped with rJe } \\
\begin{array}{c}\text { Mustard growing in subsoil pre- } \\
\text { viously uncropped }\end{array}\end{array}$ & $12 \cdot 6$ & $2 \cdot 27$ \\
\cline { 1 - 2 }
\end{tabular}


These should be compared with the figures on p. 45 . Although the subsoil lay fallow for a long time it produced no plant food but is just as poor as the subsoil that has been previously cropped. These observations give us a clue that must be followed up in answering our next question.

What has the plant food been made from? Clearly it is not made from the sand, the clay or the chalk since all these occur in the subsoil. We have seen (Chap. I.) that the top soil differs from the subsoil in containing a quantity of material that will burn away and is in part at any rate made up of plant remains. It will be easy to find out whether these remains furnish any appreciable quantity of plant food.

Fill one pot with surface soil and another with the same weight of surface soil well mixed up with 30 grams of plant remains-pieces of grass, or stems and leaves of other plants cut up into fragments about half an inch long. At the same time put up two pots of subsoil, one of which, as before, is mixed with 30 grams of plant remains, and also put up two pots of sand, one containing 30 grams of plant remains and the other none. Sow all six pots with mustard and keep watered and well tended. The result of one experiment is shown in Fig. 23 and the weights of the crop in grams were:-

\begin{tabular}{|r|c|c|}
\hline & Green weight & After drying \\
\cline { 1 - 2 } Top soil and pieces of plants (Pot 6) & $42 \cdot 0$ & $5 \cdot 0$ \\
Top soil alone (Pot 3) ................. & $\frac{17 \cdot 7}{24 \cdot 3}$ & $\frac{2 \cdot 6}{2 \cdot 4}$ \\
Difference in top soil ............ & & \\
\hline
\end{tabular}




\begin{tabular}{|r|c|c|}
\hline & Green weight & After drying \\
\hline Subsoil and pieces of plants (Pot 7) & 10.5 & 1.9 \\
Subsoil alone (Pot 4) ................. & $\frac{5 \cdot 1}{5 \cdot 4}$ & $\frac{1 \cdot 1}{0.8}$ \\
Difference in subsoil ............. & & \\
\hline
\end{tabular}

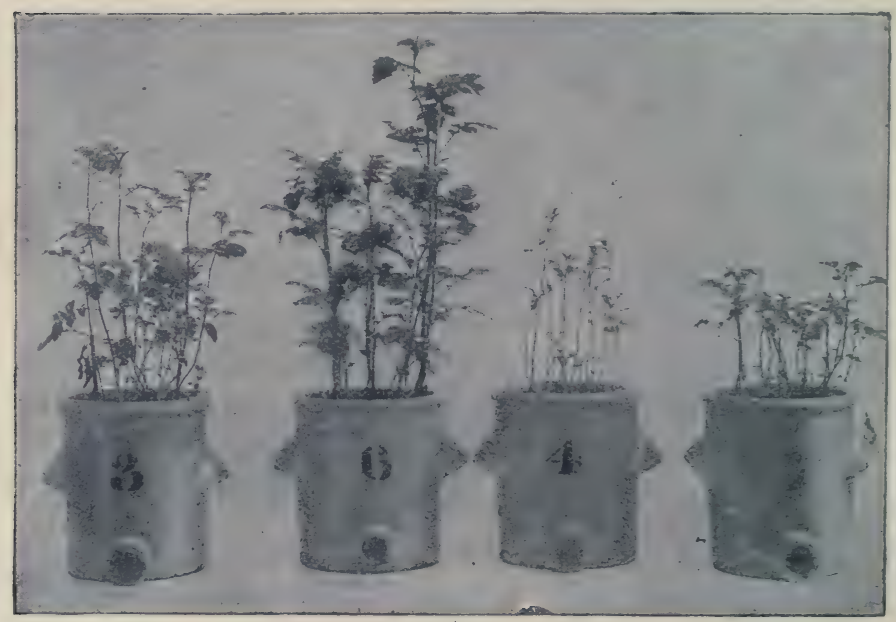

Fig. 23.

Pieces of grass, leaves, etc. change into plant food in the surface but not to any great extent in the subsoil. Mustard is growing in surface soil (Pot 3), in surface soil and pieces of grass (Pot 6), in subsoil (Pot 4), and in subsoil and grass (Pot 7)

Now let us look at these results carefully. The experiment with surface soil shows that the pieces of stem and leaf have furnished a good deal of food to the mustard and have caused a gain of 24.3 grams in the crop. If we knew what the pieces were made of we 
could push the experiment still further and find out more about plant food, but this involves chemical problems and must be left alone for the present. We can, however, say that plant remains are an important source of plant food, and since we suppose the black material of the soil to be made of plant remains (see p. 36), it will be quite fair to say also that this black material, the humus, is a source of plant food. We have therefore answered the question we set, and we can explain some at any rate of the differences between the surface soil and the subsoil. The surface soil contains a great deal of the black material, which forms plant food, while the subsoil does not. Thus plants grow well on the surface soil and starve on the subsoil. We can also explain why gardeners and farmers speak of black soils as rich soils; they contain more than other soils of this black material that makes plant food. Still further, we can explain why the farmer often sows plants like mustard, tares or clover, and then ploughs them into the ground. They are not wasted, but they make food for the next crop that goes in.

Now let us turn to the results of the subsoil experiments. The leaves and stems have increased the crop, but only by 5.4 grams: they have not been nearly so effective as in the surface soil. It is evident that the mustard did not feed directly on the leaves and stems put in; if it had there should have been an equal gain in both cases. The leaves and stems clearly have to undergo some change before they are made into plant food and the soil has something to do with this change. After the crops are cut the soils should be tipped out and examined. More of the original pieces of leaf and stem are found in the subsoil than in the surface 
soil. That is to say, there has been more change in Pot 6 containing surface soil than in Pot 7 containing subsoil. The "something," whatever it may be, that changes plant remains like leaves, stems, pieces of grass, roots, etc. into plant food therefore acts better in the surface soil than in the subsoil. Here then we have another difference between surface and subsoils.

summary. The experimental results obtained in this chapter may now be summed up as follows:-

(1) Plant food is present in the top soil only and not to any extent in the subsoil.

(2) There is not much present, so little indeed that we could not detect it by weighing.

(3) It is, however, always being made in the top soil, if water is present. Only little is made from the subsoil.

(4) The remains of leaves, stems, roots, etc. furnish an important source of plant food.

(5) But they have first to undergo some change, and the agent producing this change is more active in the top soil than in the subsoil.

(6) The top soil is much the most useful part of the soil and should never be buried during digging or trenching, but always carefully kept on top. 


\section{CHAPTER VII}

\section{THE DWELLERS IN THE SOIL}

\section{Apparatus required.}

Garden soil. Six bottles and corks [1]. Twelve Erlenmeyer Alasks, 50 c.c. capacity [2]. Cotton wool. Milk (about half a pint). Leaf gelatine. Soil baked in an oven. Six saucers [3]. The apparatus in Fig. 28 (two lots). Wash bottle containing lime water (Fig. 27, also p. 19).

In digging a garden a number of little animals are found, such as earthworms, beetles, ants, centipedes, millipedes and others. There are also some very curious forms of vegetable life. By carefully looking about it is not difficult to find patches of soil covered with a greenish slimy growth; they are found best under bushes where the soil is not disturbed, or else where the soil has been pressed down by a footmark and not touched since. Any good soil left undisturbed for a time shows this growth.

Put some fresh moist garden soil into a bottle and cork it up tightly so that it keeps moist. Write the date on the bottle and then leave it in the light where you can easily see it. After a time-sometimes a long, sometimes a shorter time-the soil becomes covered with a slimy growth, greenish in colour, mingled here and there with reddish brown. The longer the 
soil is left the better. Often after several months something further happens; little ferns begin to grow and they live a very long time indeed. There is at Rothamsted a bottle of soil that was put up just like this as far back as 1874. For a number of years past a beautiful fern has been growing inside the bottle, and even now it is very healthy and vigorous. If, instead of being kept moist, the rich garden soil is left in a dry shed during the whole of the winter so that it gradually loses its moisture, it will generally show quite a lot of white fluffy growth.

All of these living things are very wonderful, and some, especially earthworms, are very useful to gardeners and farmers.

After a shower of rain look carefully in the garden or else on a lawn, common, or pasture field where the grass is closely grazed by cattle or does not naturally grow long, and you will find numbers of tiny heaps of soil scattered about. Carefully brush away a heap and a little hole is seen, now hit the ground near it a few times with a stick or stamp on it with your foot and the worm, if he is near the top, comes up. When he is safely out of the way dig carefully down with a knife or trowel so as to examine the hole or "burrow." At the top you generally find it lined with pieces of grass or leaves that the worm has pulled in; lower down the lining comes to an end, but the colour of the burrow is redder than that of the rest of the soil wherever the soil has a greenish tinge. These holes are useful because they let air and water down into the soil.

The following experiment shows what earthworms can do. Fill a pot with soil from which all the worms have been carefully picked out and another 
with soil to which earthworms have beeu added, one worm to every pound of soil. Leave them out of doors where the rain can fall on to them. You can soon see the burrows and the heaps of soil or "casts" thrown up by the worms: these casts wash or blow

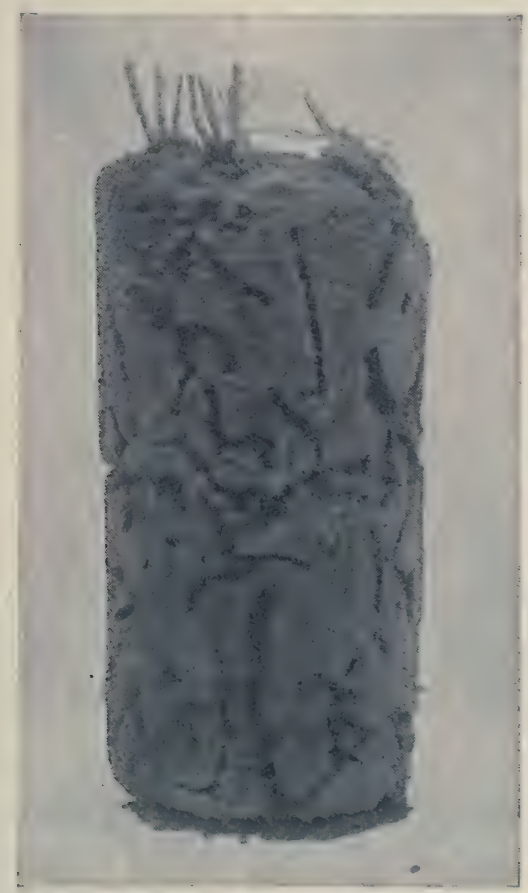

Fig. 24.

Soil in which earthworms have been living and making burrows

over the surface of the soil, continually covering it with a thin layer of material brought up from below. Consequently the soil containing earthworms always has 
a fresh clean look. After some time the other soil becomes very compact and is covered with a greenish slimy growth. When this happens carefully turn the pots upside down, knock them so as to detach the soil and lift them off. The soil where the earthworms had lived is full of burrows and looks almost like a sponge. Fig. 24 shows what happened in an experiment lasting from June to October. The other soil where there were no earthworms shows no such burrows and is rather more compact than when it was put in.

Earthworms therefore do three things:-

(1) They make burrows in the ground and so let in air and water.

(2) They drag leaves into the soil and thus help to make the mixture of soil and leaf mould.

(3) They keep on bringing fresh soil up to the surface, and they disturb the surface so much that it is always clean and free from the slimy growth.

All these things are very useful and so a gardener should never want to kill worms. The great naturalist, Darwin, spent a long time in studying earthworms at his home in Kent and wrote a very interesting book about them, called Earthworms and Vegetable Mould. He shows that each year worms bring up about $\frac{1}{50}$ th of an inch of soil, so that if you laid a penny on the soil now and no one took it, in 50 years it might be covered with an inch of soil. Pavements that were on the surface when the Romans occupied Britain are now covered with a thick layer of soil.

But besides these there are some living things too small to see, that have only been found by careful experiments, but you can easily repeat some of these 
experiments yourselves. Divide a little rich garden soil into two parts and bake one in the kitchen oven on a patty tin. Pour a little milk into each of two small flasks, stop up with cotton wool (see Fig. 25) and boil for a few minutes very carefully so that the milk does not boil over, then allow to cool. Next carefully take out the stopper from one of the flasks and drop in a little of the baked soil, label the flask "baked soil" and put back the stopper. Into the other flask
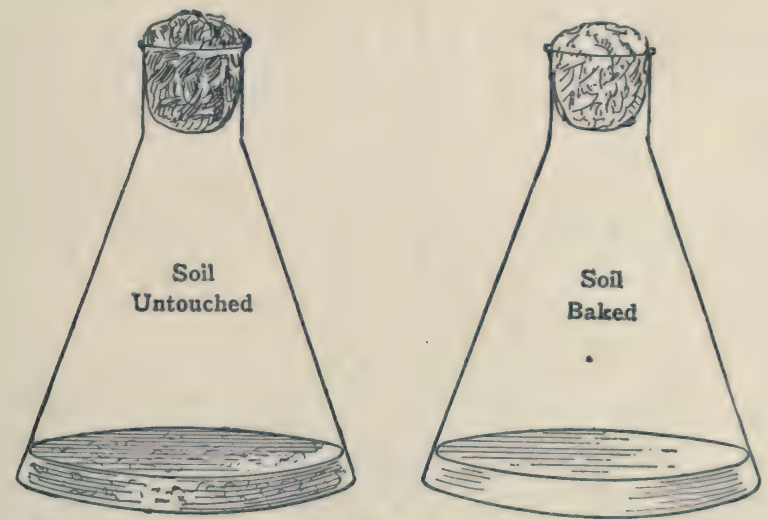

Fig. 25.

Fresh soil turns milk bad, but baked soil does not

drop a little of the untouched soil and label it; leave both flasks in a warm place till the next day. Carefully open the stoppers and smell the milk: the baked soil has done nothing and the milk smells perfectly sweet; the unbaked soil, on the other hand, has made the milk bad and it smells like cheese. If you have a good microscope you can go further: look at a drop of the liquid from each flask and you find in each case the 
round fat globules of the milk, but the bad milk contains in addition some tiny creatures, looking like very short pins, darting in and out among the fat globules. These living things must have come from the unbaked
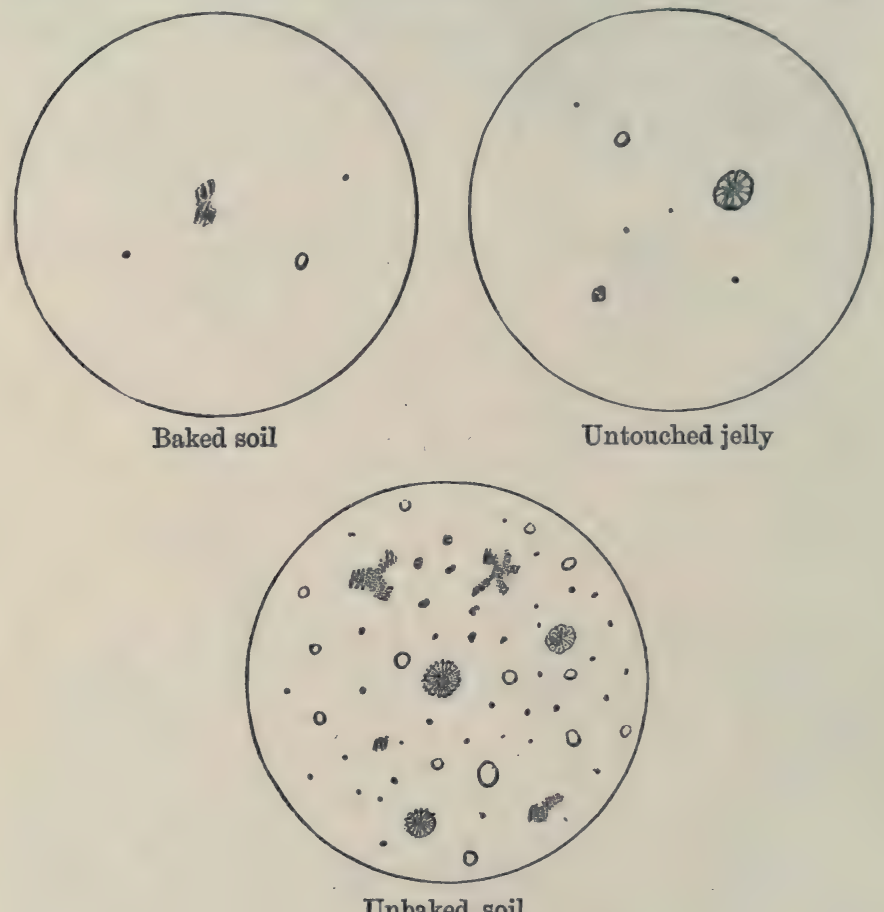

Fig. 26.

Soils contain tiny things that grow on gelatine

soil or they would have been present in both flasks: they must also have been killed by baking in the oven.

Another experiment is easy but takes a little longer to show. Mix two sheets of leaf gelatine with a quarter 
of a pint of boiling water, pour into each of three saucers, and cover over with plates. Then stir up some baked soil in a cup half full of cold boiled water, and quickly put a teaspoonful of the liquid into a second cup, also half full of cold boiled water. Stir quickly and put a spoonful on to the jelly, tilting it about so that it covers the whole surface and label the saucer "baked

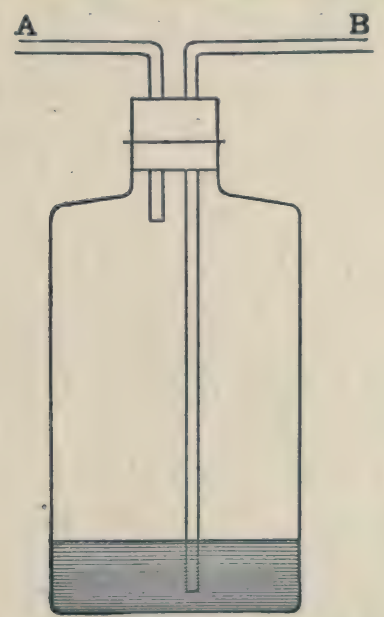

Fig. 27.

Bottle contrining lime water, used to show that breath makes lime water milky

soil." Do the same with the "unbaked soil," labelling the saucer; leave the third jelly alone and label it "untouched." Cover all three with plates and leave in a warm place. After a day or so little specks begin to appear on the jelly containing the unbaked soil, but not on the others (Fig. 26); they grow larger, and before long they change the jelly to a liquid. The other jellies 
show very few specks and are little altered. These creatures making the specks came from the soil because so few are found on the jelly alone; they were killed in the baking and so do not occur on the baked soil jelly.

You can also show that breathing is going on in the soil even after you have picked out every living thing that you can see. First of all you must do a little experiment with your own breathing so that you may know how to start. Shake up a little fresh lime with water and leave it to stand for 24 hours. Pour a little of the clear liquid into a flask or bottle fitted with a cork and two tubes, one long and one short like that shown in Fig. 27. Then breathe in through the tube $\boldsymbol{A}$ so that the air you take in comes through the lime water: notice that no change occurs. Next breathe out through the tube $B$ so that your breath passes through the lime water; this time the lime water turns very milky. You therefore alter in some way the air that you breathe: you know also that you need fresh air.

Now we can get on with our soil experiments. Take two small flasks of equal size fitted with corks and joined by a glass tube bent like a $U$ with the ends curled over. Put some lime water into each flask and a little water in the $U$-tube. Now make a small muslin bag like a sausage: fill it with moist fresh garden soil, tie it up with a silk thread and hang it in one of the flasks by holding the end of the thread outside and pushing in the cork till it is held firmly (see Fig. 28). Fix on the other flask, and after about five minutes mark the level of the liquid with a piece of stamp paper; leave in a warm place but out of the sun. 
In one or two days you will see that the water in the $\mathrm{U}$-tube has moved towards the soil flask, showing that some air has been used up by the soil; further, the lime water has turned milky. But in the other flask, where there is no soil, the lime water remains quite clear.

This proves, then, that some of the tiny creatures want air just as much as we do. The air reaches them through passages in the soil, through the burrows of earthworms and other animals, or by man's efforts in digging and ploughing.

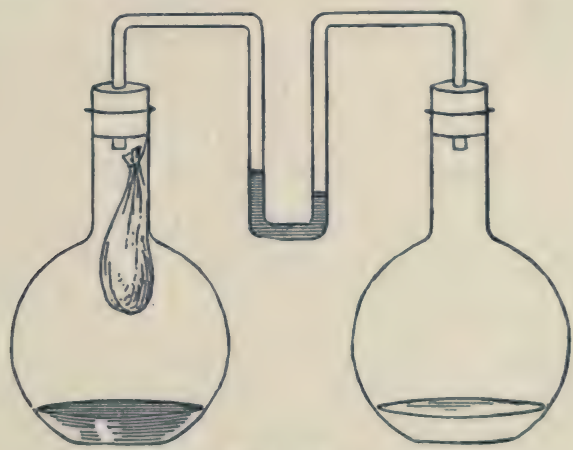

Fig. 28.

A bag of soil is fixed into a flask containing lime water. In a few days some of the air has been used up, and the lime water has turned milky

Now try the experiment with very dry garden soil: little or no change takes place. As soon as you add water, however, breathing begins again, air is absorbed and the lime water turns milky just as before. Water is therefore wanted just as much as air.

If you had very magnifying eyes and could see things so enlarged that these little creatures seemed to 
you to be an inch long, and if you looked down into the soil, it would seem to you to be an extraordinarily wonderful place. The little grains of soil would look like great rocks and on them you would see creatures of all shapes and sizes moving about, and feeding on whatever was suitable to them, some being destroyed by others very much larger than themselves, some apparently dead or asleep, yet waking up whenever it becomes warmer or there was a little more moisture. You would see them changing useless dead roots and leaves into very valuable plant food; indeed it is they that bring about the changes observed in the experiments of Chap. vI. Occasionally you would see a very strange sight indeed-a great snake-like creature, over three miles long and nearly half a mile round, would rush along devouring everything before it and leave behind it a great tunnel down which a mighty river would suddenly pour, and what do you think it would be? What you now call an earthworm and think is four inches long, going through the soil leaving its burrow along which a drop of water trickles! That shows you how tiny these little soil creatures are.

These busy little creatures are called microorganisms because of their small size. But they are not all useful. Some can turn milk bad as we have already seen, and therefore all jugs and dishes must be kept clean lest any of them should be present. Others can cause disease. It has happened that a child who has cut its finger and has got some soil into the cut, and not washed it out at once, has been made very ill. You may sometimes notice sheep limping about in the fields, especially in damp fields; an organism gets into the foot and causes trouble. 
Summary. The soil is full of living things, some large like earthworms, others very small. Earthworms are very useful: they make burrows in the soil, thus allowing air and water to get in: they drag in leaves and they keep on covering the surface with soil from below. Besides these and the other large creatures, there are micro-organisms so small that they cannot be seen without a very good microscope: they live and breathe and require air, water and food. Some are very useful and change dead parts of plants or animals into valuable plant food. Almost anything that can be consumed by fire can be consumed by them. Others are harmful. 


\section{CHAPTER VIII}

\section{THE SOIL AND THE PLANT}

\section{Apparatus required.}

Dry powdered soil, sand, clay, leaf mould, seeds. Six funnels, disks, stands and glass jars [3]. Six glass tubes about $\frac{1}{2}$ in. diameter and $18 \mathrm{in.} \mathrm{long} \mathrm{[2].} \mathrm{Muslin,}$ string, three beakers. Six lamp chimneys standing in tin lids [3]. Pot experiments ( $p$. xiii), growing plant. Two test tubes fitted with split corks (Fig. 35).

If you have ever tried to grow a plant in a pot you must have discovered that it needs much attention if it is to be kept alive. It wants water or it withers; it must be kept warm enough or it is killed by cold; it has to be fed or it gets yellow and starved; also it needs fresh air and light. These five things are necessary for the plant:

\section{Water, \\ Warmth, \\ Food, \\ Fresh air, \\ Light.}

We may add a sixth: there must be no harmful substance present in the soil.

Wild plants growing in their native haunts get no attention and yet their wants are supplied. We will try and find out how this is done. 
Water comes from the rain, but the rain does not fall every day. How do the plants manage to get water on dry days? A simple experiment will show you one way. Put about four tablespoonsful of dry soil on to the funnel shown in Fig. 29 and then pour on two tablespoonsful of water. Measure what runs through. You will find it very little; most of the water sticks to the soil. Even after several days the soil was
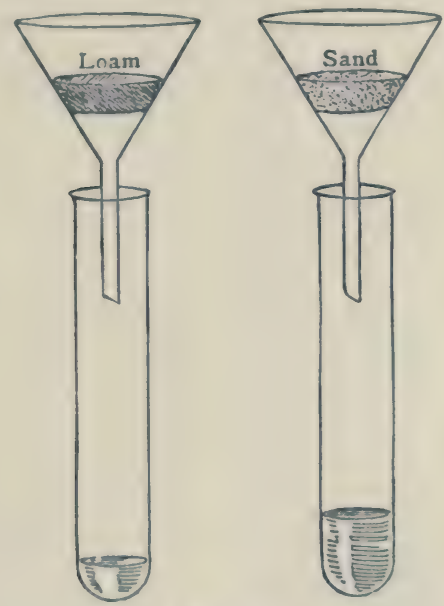

Fig. 29.

Loam and sand both retain water, but loam better than sand

still rather moist. Soil has the power of keeping a certain amount of water in reserve for the plant, it only allows a small part of the rain to run through. Do the experiment also with sand, powdered clay, and leaf mould. Some water always remains behind, but less in the case of sand than in the others.' In one experi- 
ment 30 cubic centimetres of water were poured on to 50 grams of soil but only 10 cubic centimetres passed through, but when an equal amount was poured on to 50 grams of sand no less than 20 cubic centimetres passed through. Very sandy soils, therefore, possess less power of storing water than do soils with more clay or mould in them, such as loams, clays or black soils.

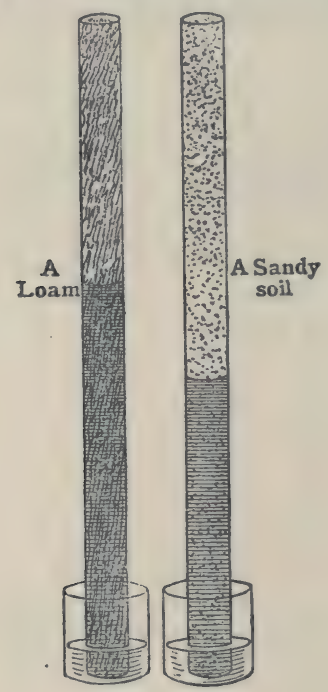

Fig. 30.

Water can rise upwards in soil.

It can, in fact, travel in any

direction, from wet to dry places

Further, water has a wonderful power of passing from wet places to dry places in the soil. Tie a piece of muslin over the end of a tube and fill with dry soil, tapping it down as much as you can, then stand the tube in water as in Fig. 30. Fill another with sand 


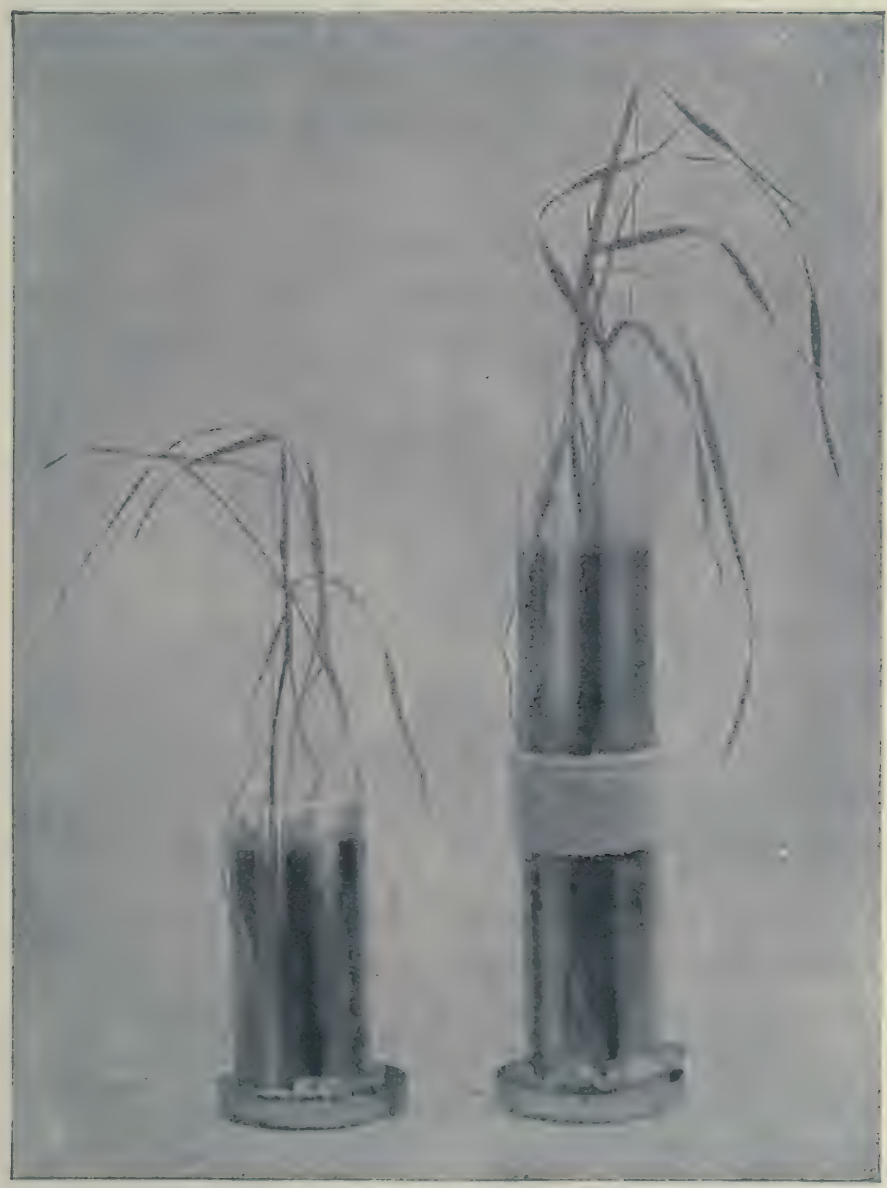

Fig. 31

Wheat growing in soils supplied from below with water. All the water the plant gets has to travel upwards 
and place in water. Notice that the water at once begins to rise in both tubes and will go on for a long time, always passing from the wet to the dry places. It rises higher in the soil than it does in the sand. Enough water may pass up the tube in this way to supply the needs of a growing plant. Fill a glass lamp chimney with dry soil, packing it down tightly, put into water and then sow with wheat. The plants grow very well. A longer tube may be made from two chimneys fastened together by means of a tin collar stuck on with Canada balsam or sealing wax (Fig. 31). Our plants grew well in this also, but on a sandier soil, where the water could not rise so high, it might happen that they would not.

Thus we shall expect great differences in the moisture of various soils. In some districts there is much more rain than in others, and therefore the soils get a larger supply of water. Sandy soils allow water to run through while a loam holds it like a sponge, in a loam also the water readily moves from wet to dry places. Further, water runs down hills and collects in low-lying hollows or valleys; here, therefore, the soil is moister than it is somewhat higher up. What will be the effect of these moisture differences on plants?

You must find out in two ways. Visit a soil that you know is dry-a sandy, gravelly or chalky soil in a high situation-and look carefully at the plants there, then go to some moister, lower ground and see what the plants show. You cannot be quite certain, however, that anything you see is simply due to water supply, because there may be other differences in the soil as well. So you must try the second method, and that is to find out by experiments what is the effect of varying 
quantities of water on the plant growth. Both methods must be used, but it may be more convenient to start the experiments first, and while they are going on to collect observations in your rambles.

Fill four glazed pots with dry soil: keep one dry; one only just moist; the third is to be very moist and should be watered more frequently than the second; and the fourth is to be kept flooded with water, any way

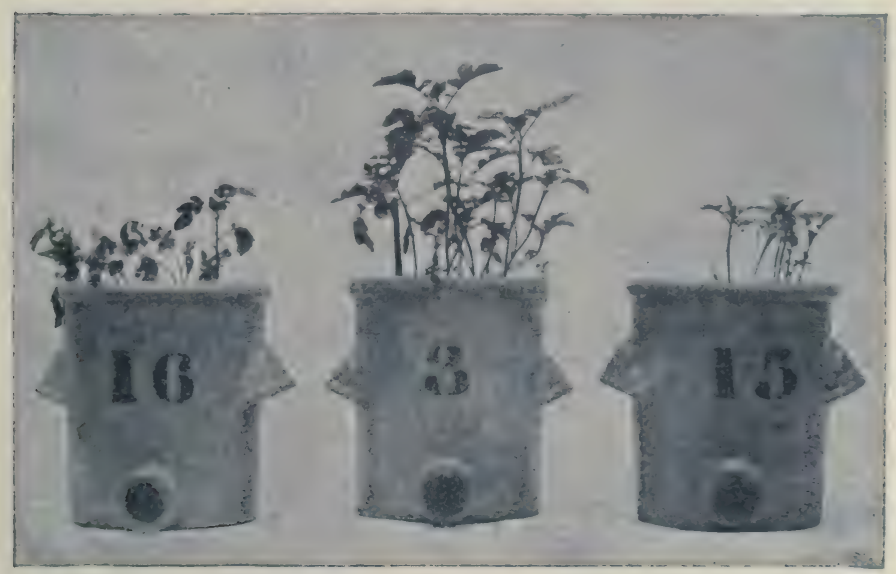

Fig. 32.

Mustard growing in soils supplied with varying quantities of water. 16 very little water, 3 a nice amount of water, 15 too much water

out being stopped up. Sow wheat or mustard in all four and keep out of the rain. The result of one experiment with mustard is shown in Fig. 32. Where no water was supplied there was no growth and the seeds remained unaltered. Where only little water was supplied (Pot 16) the plants made some growth, but not very much: the leaves were small and showed no great vigour; 
where sufficient water was given (Pot 3) the plants grew very well and had thick stems and large leaves; where too much water was given (Pot 15) the plants were very sickly and small.

The weights were:-

\begin{tabular}{|r|c|c|}
\hline & Green weight & After drying \\
\cline { 1 - 2 } Plants with too much water ........ & 3.9 & 0.5 \\
" " too little water ......... & 5.3 & 0.9 \\
$"$ " a nice quantity of water & $17 \cdot 7$ & 2.6 \\
\hline
\end{tabular}

Fig. 33 shows two pots of wheat, one kept only just sufficiently moist for growth, the other kept very moist but not too wet. You can see what a difference there is; in the drier pot the leaves are rather narrow and the plants are small, in the moister pot the leaves are wide and the plants big. But there was also another difference that the photograph does not bring out very well-the plants in the rather dry soil were, as you can see, in full ear, ripe and yellow, while those in the very moist soil were still green and growing. We see then (1) that on moist soils there is greater growth than on dry soils, but the plants do not ripen so quickly; (2) in very wet soils mustard-and many other plants also-will not grow.

Water is not itself harmful. It is easy to grow many plants in water containing the proper food, but air must be blown through the water at frequent intervals. In the water-logged soil of Pot 15 the trouble arose not from too much water but from too little air. Air is wanted because plants are living and 
breathing in every part, in the roots as well as in the leaves.

Now turn to what you have seen in your walks. You would probably notice that on the drier, sandy or gravel ground there was nothing like as great a growth of grass or of other plants as on the moister soil. This is so much like what we found in the pot experiments

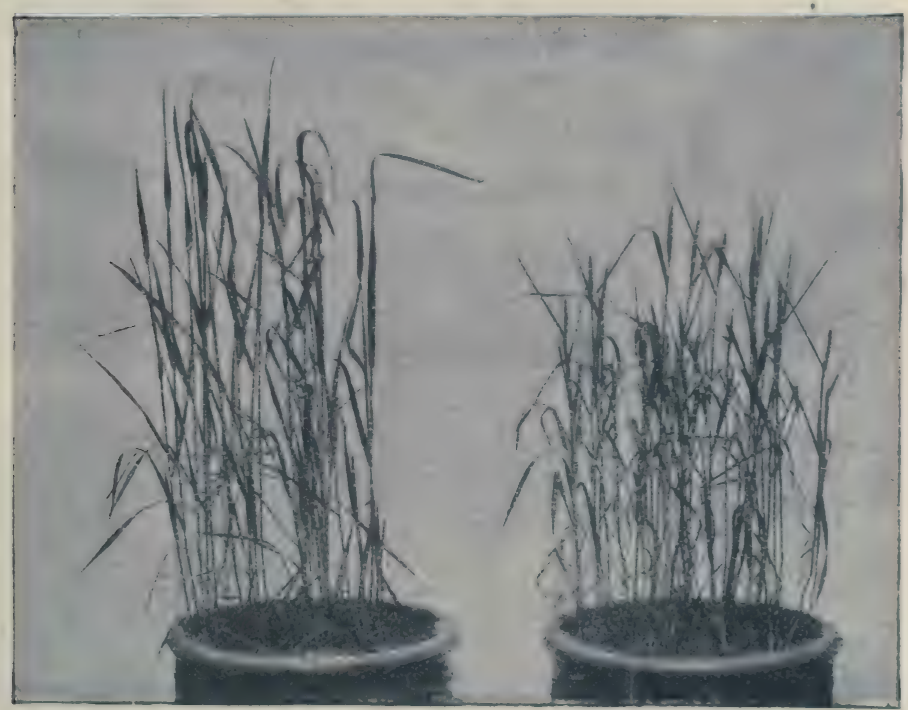

Fig. 33.

This wheat growing on very this wheat growing on rather moist soil was still green and growing vigorously,

whilst dxy soil was yellow and ripe

that we shall not be wrong in supposing that the difference in water supply largely accounted for the difference in growth. But you may also have noticed something else. Plants in the drier soil have generally 
narrow leaves and the grasses are rolled up and fine, whilst those on the damp soil, including the grasses, have usually broad leaves. Thus in the dry sandy soil you may find broom, spurrey, sheep's fescue, pine trees, all with narrow leaves; whilst on the moister soil you

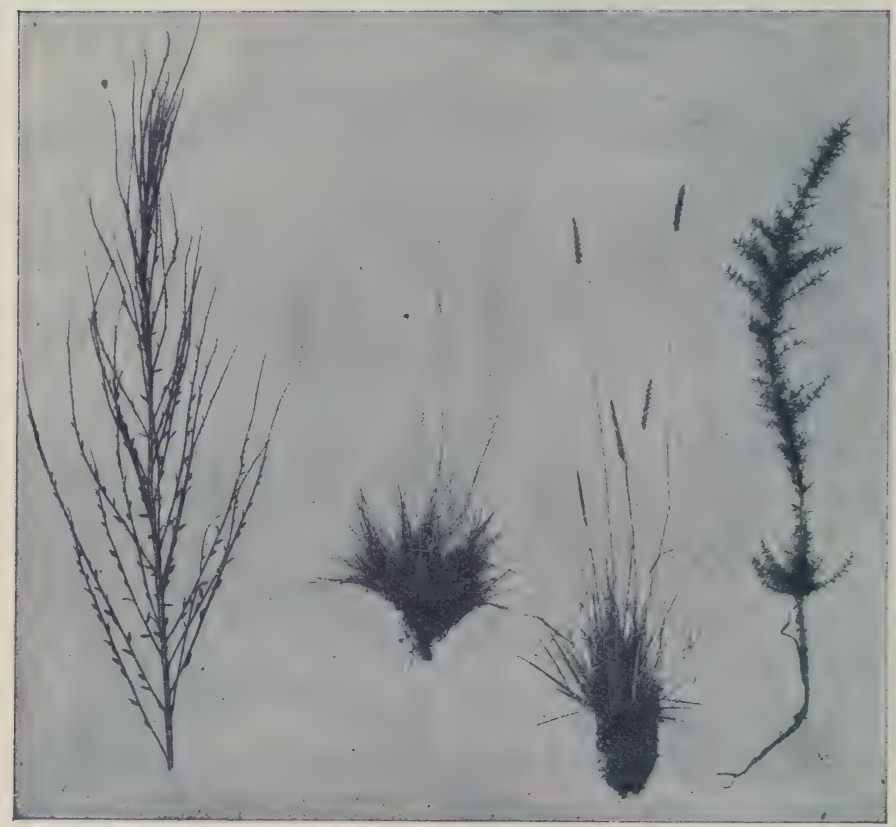

Fig. $34 a$.

Plants collected on dry sandy soil. Broom, sheep's fescue, crested dogstail and gorse, all with narrow leaves

may find burdock, primroses, cocksfoot and other broadleaved plants. Figs. $34 a$ and $b$ show some plants we found on a dry, gravelly patch on Harpenden common, and on a moist loam in the river valley below. 
Before we can account for this observation, we must ascertain a little more closely what becomes of the water the plant takes up. It certainly does not all stay in the plant, and the only way out seems to be through the leaves. Put a test tube on the leaf of a growing plant and fix a split cork round the stem: leave in sun-

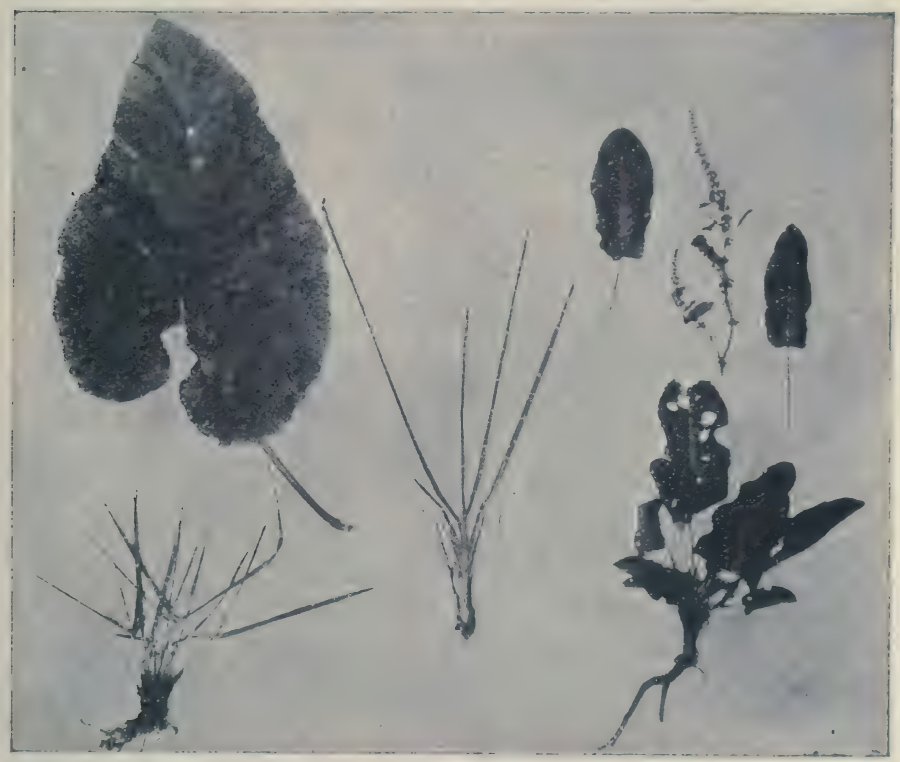

Fig. $34 \mathrm{~b}$.

Plants collected on moist loam. All have wide leaves

light for a few hours and notice that water begins to collect in the test tube (Fig. 35). The experiment shows that water passes out of the plant through the leaves.

This experiment was first made by Stephen Hales, and described by him thus in 1727: "Having by many 
evident proofs in the foregoing experiments seen the great quantities of liquor that were imbibed and perspired by trees, I was desirous to try if I could get any of this perspiring matter; and in order to do it, I took several glass chymical retorts, $b a p$ [Fig. 36] and put the boughs of several sorts of trees, as they were growing with their leaves on, into the retorts, stopping up the mouth $p$ of the retorts with bladder. By this means I got several ounces of the perspiring matter of vines, figtrees"-and other trees, which "matter" Hales found to be almost pure water. The test tube experiment

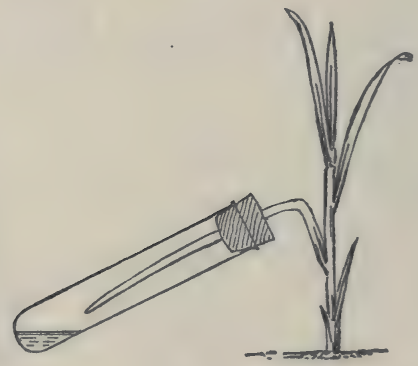

Fig. 35.

Plants give out water through their leaves

should now be made with a narrow-leaved grass like sheep's fescue and with a wide-leaved grass like cocksfoot. You will find that wide-leaved plants pass out more water than those with narrow leaves, and hence wide-leaved plants occur in damp situations or on damp soils like loams and clays, while narrow-leaved plants can grow on dry, sandy soils.

Another thing you will notice is that fields lying at the side of a river and liable to be flooded, and fields 
high up in wet hill districts, are covered with grass. In a clay country there is also a great deal of grass land and not much ploughed land; if you live where there is much clay you can easily discover the reason. Clay becomes very wet and sticky when rain falls, and very hard in dry weather: it is, therefore, difficult to cultivate. Farmers cannot afford to spend too much money

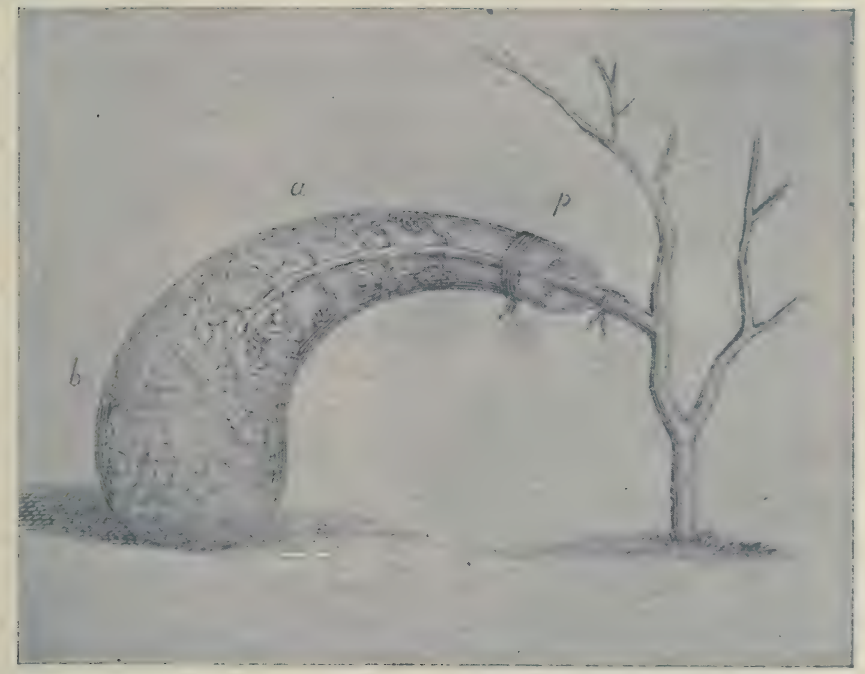

Fig. 36.

Stephen Hales's Experiment (from Vegetable Staticks, Vol. r. 1727)

on cultivation, and so they prefer grass, because once it is established it goes on indefinitely and does not want ploughing up and re-sowing. And besides, farmers have learned by experience that grass can tolerate more water and less warmth than most other English crops. There is much more grass land in those parts of England where the rainfall is high and the temperature rather 
low-e.g. the northern parts of England-than in the eastern counties where the rainfall is low.

The difference in water supply, therefore, leads us to expect the following differences between sandy soils and clays or loams:-

On sandy soils (the water content being small) the wild plants and trees usually have small leaves. Cultivated plants do not give very heavy crops, but they ripen early.

On clay soils (the water content being good) wild plants and trees usually have larger leaves. Cultivated plants give good crops, but they ripen rather late. If the water content is too good or the clay is too sticky the land is generally put into grass.

Plants require to be sufficiently warm. Some like tropical heat and can only be grown in hot houses; others can withstand a certain amount of cold and will grow up on the mountains. Our common cultivated crops come in between and will not grow in too cold or exposed a situation; thus you find very little cultivated land $800 \mathrm{ft}$. above sea level, and not usually much above $500 \mathrm{ft}$. At this height it is left as grass land, and higher up as woodland, moor, or waste land. Grass requires less warmth and can therefore grow at greater heights than many other crops. If you start at the top of a hill in Derbyshire, and walk down, you will see that the top is moorland, lower down comes grass land, still lower you may find arable land, and if the valley is damp you will find more grass at the bottom. Figs. 37 and 38 show typical views of the hill slopes further south: they are taken near Harpenden. The top of the hill in each case is over $400 \mathrm{ft}$. above sea level, and has never been thought worth cultivating, but has always been left as 


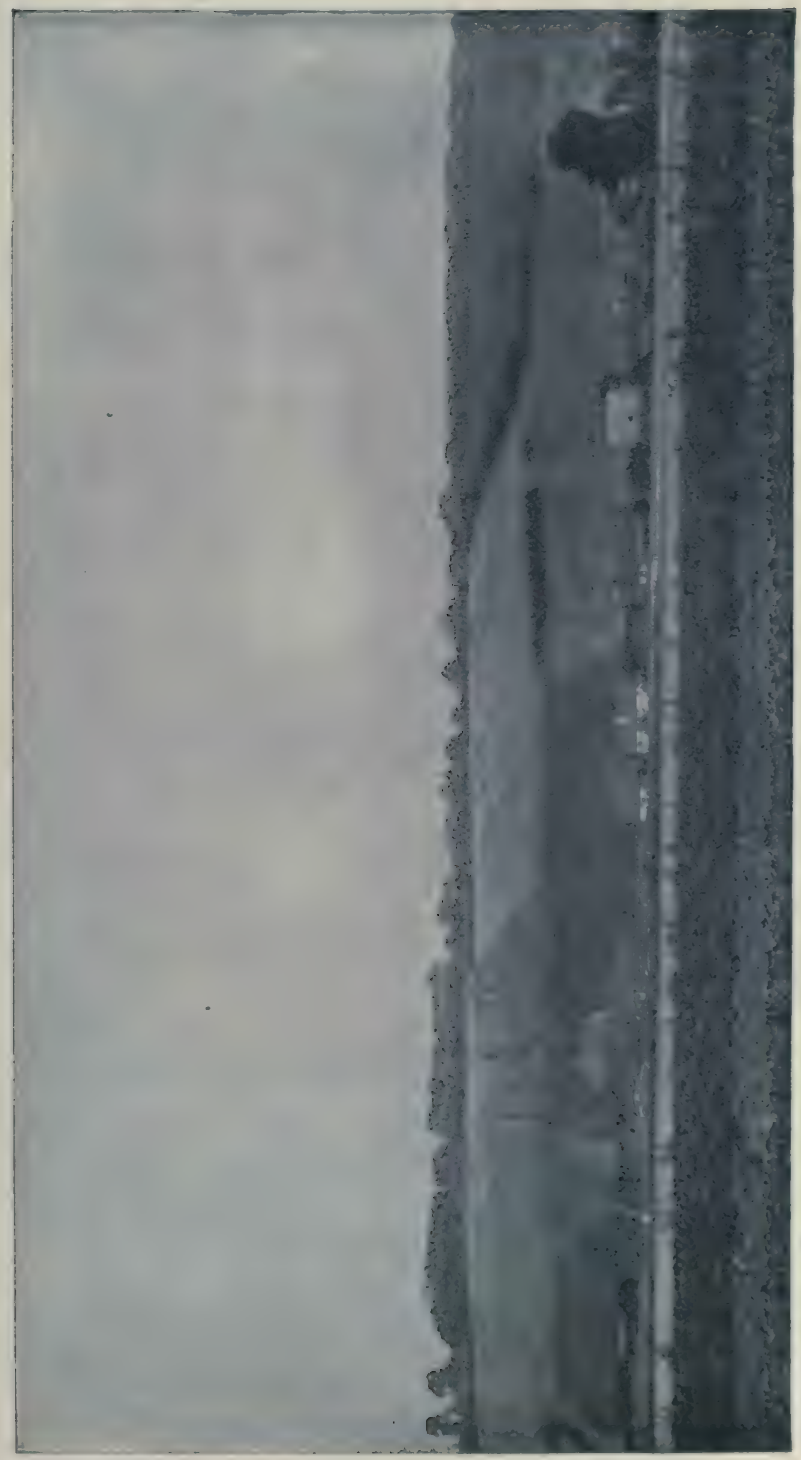

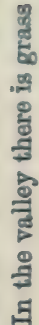

릉

.

$\geqslant$

금

코 웅

율 율

능

i. व

용

원?

$\div$.

․․

몸

융 :

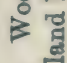

몸

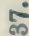

ำ 
wood because it is too exposed for farm crops. On the lower slopes the arable fields are seen, while at the bottom bordering the river is rough grass land, shown in Fig. 39. The top is too cold and windy, and the bottom too wet, to be worth cultivating.

As the plant root is alive it wants air. The effect of keeping air out can be seen by sowing some barley or onion seeds in the ground and then pouring a lot of water on and plastering the soil down with a spade. Sow another row in nicely crumbled soil, not too wet, press the seeds well in, but do not plaster the soil. This second lot will generally do much better than the first. If the ground round a plant is frequently trodden so that it becomes very hard the plant makes much less growth than if the soil were kept nice and loose. A good gardener takes very great pains in preparing his ground before he sows his seeds, and he is careful that no one should walk on his beds lest his plants should suffer.

summary. We may now collect together the various things we have learnt in this chapter. Plants require water, air, warmth, food, and light, and they will not grow if harmful substances are present. The rain-water that falls remains for some time in the soil, and does not at once run away or dry off: water can also move from wet to dry places in the soil. Therefore the plant does not need rain every day, but can draw on the stock in the soil during dry weather. A sandy soil is usually drier than a loam or a clay, especially if it lies rather high: plants growing on a sandy soil make less growth and have narrower and smaller leaves than those on a moister soil.

Situations more than five or six hundred feet above sea level are, in England, as a rule, too bleak and 


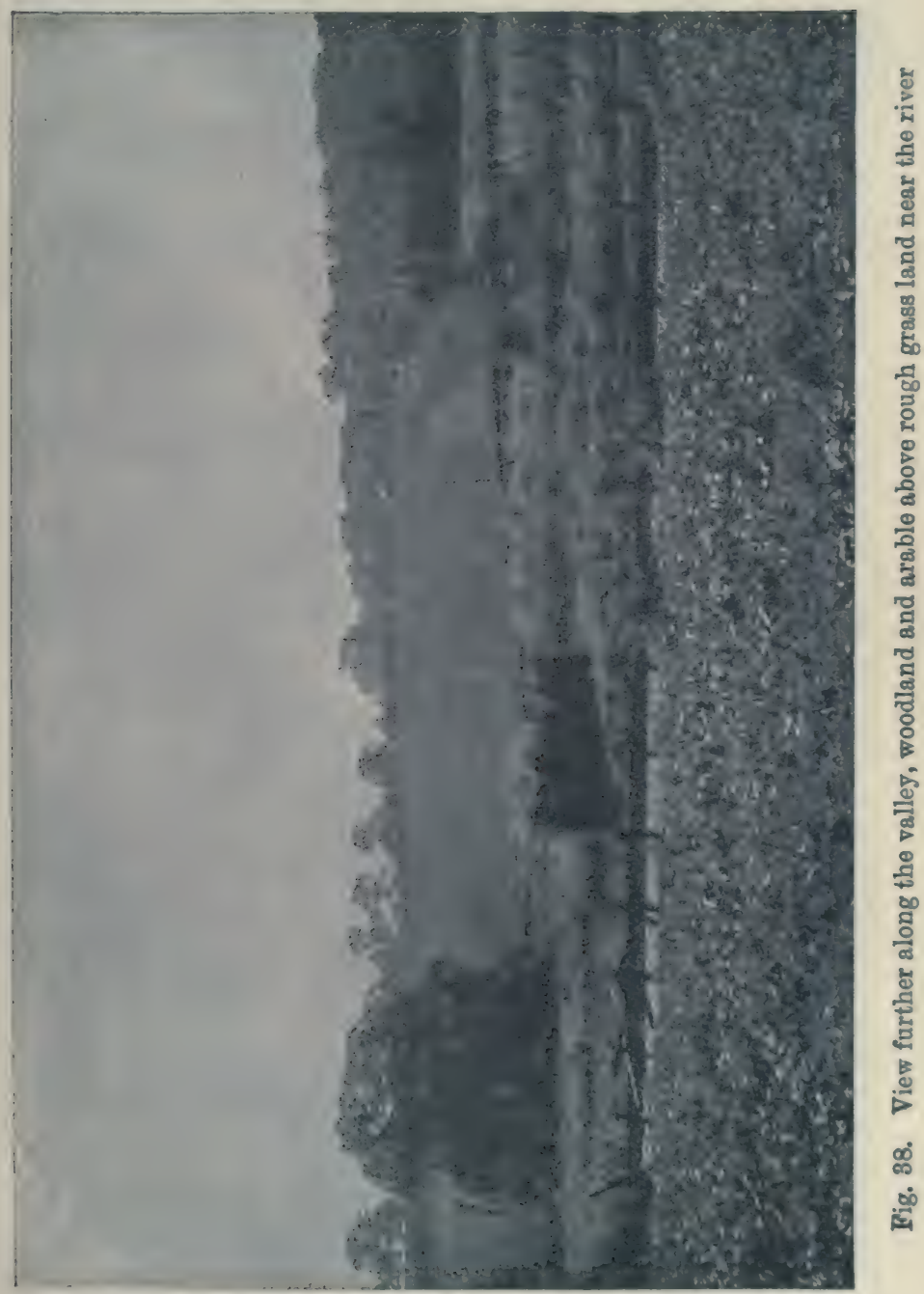


exposed for the ordinary cultivated crops. Such land is, therefore, either grass land, moorland, downland or woodland.

The roots of plants are living and require air. The soil must not be trodden too hard round them or air cannot get in, nor can it if too much water is present.

Grass can put up with more water and less warmth than most cultivated crops.

Instances of these facts may be found in going down any hill $500 \mathrm{ft}$. or more in height: the top is usually wood or waste, being too cold for crops, below this may come grass land, lower still arable land. It is both warmer and moister in the valley (since water runs down hill), and so we can account for the proverbial fertility of valleys. But just near the river, if there is one, the ground may be too wet for crops, and therefore grass is grown. Clay land that is rather too wet to plough is usually left in grass. 


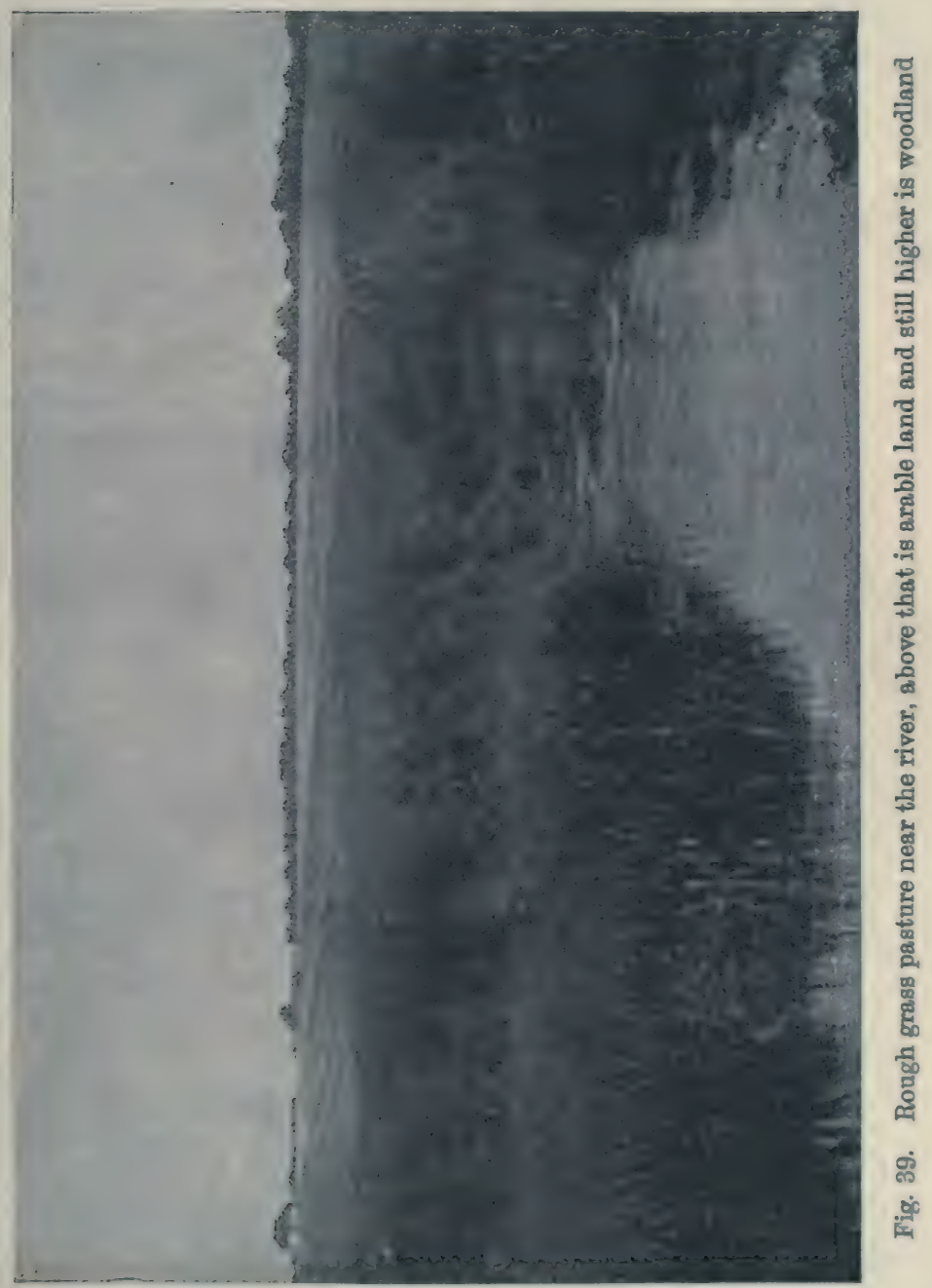

R. 


\section{CHAPTER IX}

\section{CULTIVATION AND TILLAGE}

\section{Apparatus required.}

Plot experiments, hoeing and mulching. Factory thermometer with stem 6 in. long. Soil sampler (Fig. 42, p. 88). This tool consists of a steel tube $2 \mathrm{in}$. in diameter and $9 \mathrm{in.}$ long, with a slit cut along its length and all the edges sharpened. The tube is fixed on to a vertical steel rod, bent at the end to a ring $2 \mathrm{in}$. in diameter, through which a stout wooden handle passes. It is readily made by a blacksmith.

Farmers and gardeners throughout the spring, summer and autumn, are busy ploughing or digging, hoeing or in other ways cultivating the soil. Unless all this is well done the soil fails to produce much; the sluggard's garden has always been a by-word and a reproach. In trying to understand why they do it we must remember that plant roots need water, warmth and air; if the soil is too compact or if there is too much water the plant suffers, as we have seen.

One great object of cultivation is, therefore, to prevent the soil being too compact and too wet. After the harvest the farmer breaks up his ground with a plough and then leaves it alone till seed time (Fig. 40). A gardener does the same thing with a fork in his kitchen gardenhe cannot very well elsewhere, or the plant roots might 
become too cold. If there is frost during the winter both farmer and gardener are pleased because they say the frost "mellows" the ground; you can see what they mean if you walk on a frosty morning over a ploughed field. The large clods of earth are no longer sticky, they already show signs of breaking up, and if they are not frozen too hard can easily be shattered by a kick. The change has been brought about in exactly the same

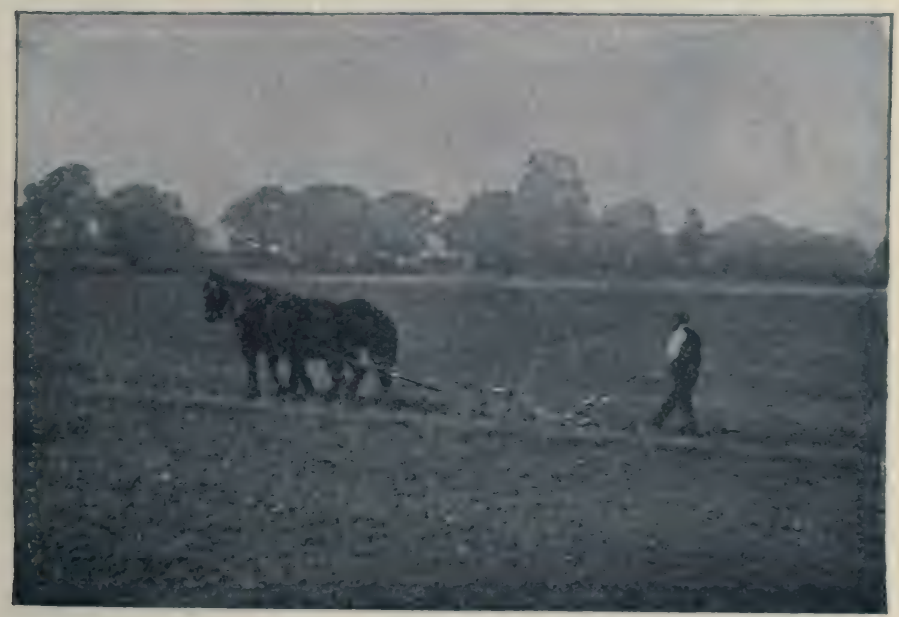

Fig. 40.

After harvest the farmer brenks up his land with a plough and then leaves it alone until seed time

way as the bursting of water-pipes by frost. When water freezes it expands with enormous force and bursts open anything that confines it; water freezing in the pores of the soil forces the little fragments apart. This action is so important that further illustrations should be looked for. A piece of wet chalk left out on a frosty night often crumbles to pieces. It is dangerous 
to climb cliffs in the early spring because pieces of rock that have been split off during the winter frosts by the expanding water may easily give way. Frost plays havoc with walls built of flints and with old bricks that are beginning to wear. If there are several frosts, with falls of rain or snow and thaws coming in between, the soil is moved about a good deal by the freezing and melting water. Bulbs and cuttings are sometimes forced out of the ground, whilst grass and young wheat may be so loosened that they have to be rolled in again as soon as the weather permits. When the ground has been dug in autumn and left in a very rough state all this loosening work of the frost is very much helped, because so much of the soil may become frozen. If in spring you dig a piece of land that has already been dug in autumn, and then try digging a piece that has not, you will find the first much easier work than the second in all but very sandy soils.

A little before the seeds are sown, the soil has to be dug or cultivated again so that it may become more level and broken into smaller pieces. The farmer then harrows and the gardener rakes it, and it becomes still finer. Very great care is bestowed on the preparation of the seed bed, and it will take you longer to learn this than any other part of outdoor gardening. The soil has to be made fine and dry, and no pains must be spared in getting it so.

When at last the soil is fine enough the seed is put in. But it is not enough simply to let the seed tumble into the ground. It has to be pressed in gently with a spade or a roller, not too hard or the soil becomes too sticky. Fig. 41 shows this operation being carried out on the farm. Then the soil should be left alone. 


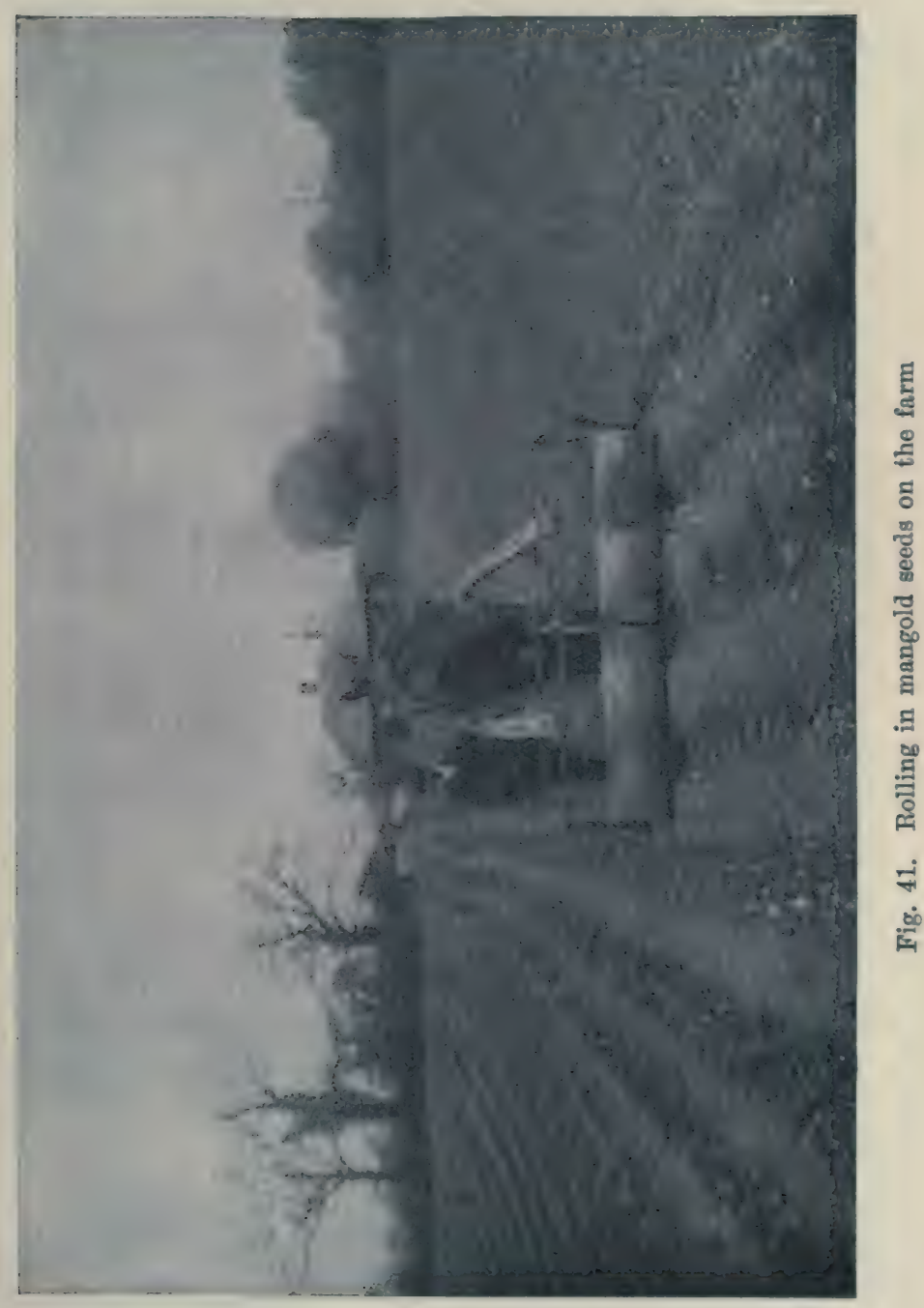


If you watch an allotment holder who grows onions really well working away at his seed-bed you will see what a beautifully fine tilth he gets. If you try to do the same you will probably fail; his seeds will be up before yours and will grow into healthier plants. Only after long practice will you succeed, and then you will have mastered one of the great mysteries of gardening.

As soon as the plants are up they have to be hoed, and the more often this is done the better. Hoeing has several useful effects on the soil; during summer time some experiments may be made to find out what these are. A piece of ground is wanted that has got no crop on it. Set out three strips each six feet wide and six feet long, leave one entirely alone, hoe the second once a week, and the third three times a week; put labels on so that no mistake can arise. The surface of the untouched plot becomes very compact and glazed in appearance; the other soils look nice and crumbly. Take the temperature of the soils by placing a thermometer into it at various depths-half inch, three inches, and six inches-also take the temperature of the air; enter up the results as in the table, which shows what happened at Harpenden.

\begin{tabular}{|c|c|c|c|c|c|}
\hline \multirow{2}{*}{ Date } & \multirow{2}{*}{$\begin{array}{l}\text { Air tem- } \\
\text { perature }\end{array}$} & \multicolumn{4}{|c|}{ Soil temperature } \\
\hline & & , & Untouched & $\begin{array}{c}\text { Hoed } \\
\text { once } \\
\text { weekly }\end{array}$ & $\begin{array}{l}\text { Hoed } \\
\text { three times } \\
\text { weekly }\end{array}$ \\
\hline $\begin{array}{c}1910 \\
\text { June 20th }\end{array}$ & $30^{\circ}$ & $\begin{array}{l}\frac{1}{2} \text { inch } \\
3 \text { inches } \\
6 \text { inches }\end{array}$ & $\begin{array}{l}35^{\circ} \\
30^{\circ} \cdot 5 \\
27^{\circ}\end{array}$ & $\begin{array}{l}31^{\circ} \cdot 5 \\
29^{\circ} \cdot 8 \\
26^{\circ} \cdot 5\end{array}$ & $\begin{array}{l}31^{\circ} \cdot 5 \\
28^{\circ} \cdot 8 \\
24^{\circ}\end{array}$ \\
\hline June 27th & $18^{\circ}$ & $\begin{array}{l}\frac{1}{2} \text { inch } \\
3 \text { inches } \\
6 \text { inches }\end{array}$ & $\begin{array}{l}17^{\circ} \cdot 5 \\
16^{\circ} \cdot 7 \\
15^{\circ} \cdot 8\end{array}$ & $\begin{array}{l}17^{\circ} \\
16^{\circ} \cdot 3 \\
15^{\circ} \cdot 5\end{array}$ & $\begin{array}{l}17^{\circ} \\
16^{\circ} \cdot 2 \\
15^{\circ} \cdot 5\end{array}$ \\
\hline
\end{tabular}


The thermometer readings are in degrees centigrade.

Remarks. June 20th: Hot surny day, there had been no rain since June 11th.

June 27th : Cold, cloudy day, several cold, wet days during the past week.

On the cold day there was very little difference between the plots, but on the hot day the hoed plots were cooler than the others. Now only the top inch is touched by the hoe, and so it appears that the layer thus loosened shields the rest of the soil from the sun's heat. If this is the case we ought to find that any other loose material would act in just the same way. We must, therefore, set out a fourth plot alongside the others, cover it with straw or cut grass (a cover like this is called a mulch), and take the temperature there. Some of the results were as follows:-

\begin{tabular}{|c|c|c|c|c|}
\hline \multirow{2}{*}{ Date } & \multirow{2}{*}{$\underset{\text { temperature }}{\text { Air }}$} & \multicolumn{3}{|c|}{ Soil temperature } \\
\hline & & & Hoed plot & Mulohed plot \\
\hline $\begin{array}{c}1910 \\
\text { Sept. 24th }\end{array}$ & $15^{\circ}$ & $\begin{array}{l}\frac{1}{2} \text { inch } \\
3 \text { inches } \\
6 \text { inches }\end{array}$ & $\begin{array}{l}17^{\circ} \cdot 5 \\
12^{\circ} \cdot 5 \\
12^{\circ} \cdot 25\end{array}$ & $\begin{array}{l}12^{\circ} \cdot 25 \\
11^{\circ} \cdot 75 \\
11^{\circ} \cdot 5\end{array}$ \\
\hline Oct. 5th & $17^{\circ}$ & $\begin{array}{l}\frac{1}{\frac{1}{2}} \text { inch } \\
3 \text { inches } \\
6 \text { inches }\end{array}$ & $\begin{array}{l}17^{\circ} \\
16^{\circ} \cdot 7 \\
15^{\circ} \cdot 5\end{array}$ & $\begin{array}{l}15^{\circ} \cdot 5 \\
15^{\circ} \\
14^{\circ} \cdot 5\end{array}$ \\
\hline
\end{tabular}

Remarks. Sept. 24th: Warm day after a rather cold spell.

Oct. 5th: After a long spell of dry, warm weather.

The untouched plot had become smothered in weeds and could no longer be used for this experiment. The mulched soil is, however, cooler even than the hoed soil, and our expectation that mulching would keep the soil cool has turned out to be correct. 
It may be expected that the hotter soil-the unhoed plot-will also be drier than the others, and this can be found out by a simple experiment. Take a sample by making a hole six inches deep with straight and not with sloping sides: this is best done by driving a tube two inches wide into the soil (Fig. 42): if you have not got such a tool you may use a trowel, but you will have

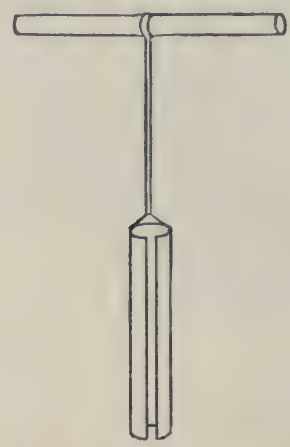

Fig. 42.

Soil sampler. (See p. 82

for description)

to be very quick and very careful. Weigh the soil-or a part of it if you have got a great deal-then set it to dry in a warm place for three or four days. Weigh again when it is dry: the difference gives the loss of water: find what it would be in a hundred parts. Our results were:- 


\begin{tabular}{|c|c|c|c|}
\hline & \multicolumn{3}{|c|}{ Percentrge of water in the } \\
\cline { 2 - 4 } & Untouched soil & $\begin{array}{c}\text { Soil hoed once } \\
\text { weekly }\end{array}$ & $\begin{array}{c}\text { Soil boed three } \\
\text { times weekly }\end{array}$ \\
\hline 1910 & $21 \cdot 1$ & $19 \cdot 5$ & $17 \cdot 9$ \\
June 4th ..... & $14 \cdot 7$ & 16.0 & 16.0 \\
June 20th...... & 19.3 & 18.4 & 20.5 \\
\hline
\end{tabular}

Remarks. June 4th: The weather is still cold and the summer has not yet begun.

June 20th: Hot day following on some hot, dry weather.

June 27th: Rain had recently fallen.

When hoeing is done in the early part of the summer it dries the soil, and the more frequent the hoeing the drier the soil (see June 4th results). But later on, when the hot weather begins, the hoed soil loses much less moisture than the untouched plot; the latter lost $6 \cdot 4$ per cent. in 16 days in the top six inches, whilst the soil hoed once weekly lost $3 \cdot 1$ per cent., and the one hoed three times weekly lost only 1.4 ; the two hoed soils are now equal, and are both moister than the untouched soil. When more rain comes they get just as wet as the others: hoeing does not prevent water from sinking in, but it does prevent water from getting lost.

Our experiment has, therefore, shown us that hoeing makes a loose layer of soil which shields the rest of the soil from the sun's heat, and prevents it getting too hot or too dry. A hoed soil is cooler and moister, and therefore better suited for the growth of plant roots than an unhoed soil. 
The mulch of straw or dried grass was found to have the same effect in conserving the water as the loose layer of soil obtained by hoeing. Some results were:-

\begin{tabular}{|c|c|c|}
\hline \multirow{2}{*}{ Date } & \multicolumn{2}{|c|}{ Percentage of moisture in } \\
\cline { 2 - 3 } $\begin{array}{c}\text { Hoed soil } \\
\text { Sept. 24th }\end{array}$ & Mulohed soil \\
\hline \begin{tabular}{l} 
Hed \\
\hline
\end{tabular} & $19 \cdot 6$ & $20 \cdot 7$ \\
\hline
\end{tabular}
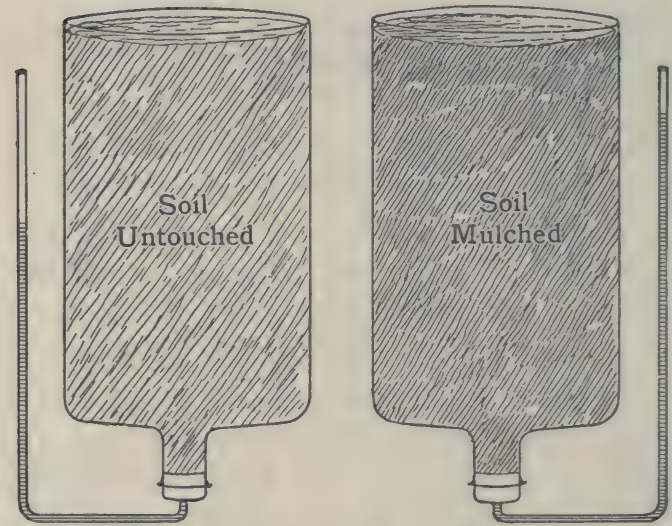

Fig. 43.

Cultivation and mulching reduce the loss of water from soils

These results are so important that some indoor experiments should be made to furnish more proof. Fix up three inverted bell jars with corks and bent tubes as shown in Fig. 43, fill all with dry soil well pressed down, then add water carefully till it appears in the glass tubes. Next day mark with stamp paper the level of liquid in each tube and then leave one jar 
untouched, carefully cultivate with a penknife every two or three days the top quarter of an inch of the second, and cover the third with a layer of grass. After a week notice again the levels of the liquid and mark with paper; you find that the water has fallen most in the untouched jar, showing that more has been lost from this than from the jars covered with a mulch either of soil or of dry grass.

A slate or flat stone acts like a mulch; if you leave one on the soil for a few days in hot weather and then lift it up on a hot day you will see that the soil underneath is quite moist; you may also find several slugs or other animals that have gone there for the sake of the coolness and the moisture. Plants and trees also keep off the sun's heat and so make the soil cold and moist. Grass land is in summer and autumn, and even in early winter, cooler near the surface than bare land. At Harpenden we found:-

\begin{tabular}{|c|c|c|c|}
\hline \multirow{2}{*}{ Date } & \multicolumn{3}{|c|}{ Soil Temperature } \\
\hline & & Grass land & Bare land \\
\hline $\begin{array}{c}1910 \\
\text { Sept. } 24 \text { th }\end{array}$ & $\begin{array}{l}\frac{1}{2} \text { inch } \\
3 \text { inches } \\
6 \text { inches }\end{array}$ & $\begin{array}{l}13^{\circ} \\
12^{\circ} \cdot 5 \\
12^{\circ} \cdot 5\end{array}$ & $\begin{array}{l}17^{\circ} \cdot 5 \\
12^{\circ} \cdot 5 \\
12^{\circ} \cdot 25\end{array}$ \\
\hline Oct. 5th & $\begin{array}{l}\frac{1}{2} \text { inch } \\
3 \text { inches } \\
6 \text { inches }\end{array}$ & $\begin{array}{l}15^{\circ} \cdot 5 \\
15^{\circ} \\
14^{\circ} \cdot 5\end{array}$ & $\begin{array}{l}17^{\circ} \\
16^{\circ} \cdot 7 \\
15^{\circ} \cdot 5\end{array}$ \\
\hline
\end{tabular}

Even if the ground is not covered a certain amount of protection is still possible. Trees are often planted round ponds to prevent evaporation of the water. The wind helps to dry the soil very much, and a hedge 
that shields from the wind not only protects the crop but also keeps the soil moist: a road with high hedges at each side remains wet for a long time after more exposed parts have dried. The effect on the temperature can be well seen on a day when a N.E. wind is blowing. Fix up on a piece of the experimental ground a little hedge made of small pea-stakes or brushwood, and take the soil temperature at one inch depth, both on the windward and on the leeward side. Two results were:-

$\begin{array}{ccc}\text { Temperate at } 1 \text { inch depth-sheltered side } & 15^{\circ} \cdot 5 \\ , " \text { " } " \text { windward side } & 14^{\circ}\end{array}$

We have already seen that on the hot day, June 20th, the top half-inch of soil was hotter than the air: the mercury in the thermometer rose directly it was put into the soil. There is nothing very unusual about this; if you touch a piece of iron lying on the soil you find it hotter than the air. Lower down the soil had the same temperature as the air, and still lower it wás cooler ${ }^{1}$. The sun's heat travels so slowly into the soil in summer that months pass before it gets far down, but then, as it takes so long to get in, it also takes a long time to get out, and it takes still longer to get either in or out if there is a mulch or if grass is growing.

During the early winter you may notice that the first fall of snow soon melts on the arable land but remains longer on the grass; towards the end of the winter, however, the reverse happens and the snow melts first on the grass. There is no difficulty in explaining this. The arable land is, as we have seen, warmer in autumn and early winter than grass land,

1 At great depths below the surface the temperature rises again from quite another cause. 
and so it melts the snow more rapidly. But during winter the grass land loses its heat more slowly, and therefore it is warmer at the end of the winter than the arable land, hence the snow melts more quickly.

In Chap. v. it was pointed out that dark coloured soils rich in humus are greatly favoured by gardeners and farmers. The value of humus can easily be shown: take a sample of soil from a garden that has for a long time been well manured and another from a field close by-next to it if you can-and find the amounts of moisture present. Two soils at Rothamsted gave the following results:-

\begin{tabular}{|r|c|c|c|c|}
\hline Date... & April 6th & May 6th & July 6th & Oct. 28th \\
\cline { 2 - 4 } & 20.0 & 18.0 & $20 \cdot 7$ & $23 \cdot 3$ \\
$\begin{array}{c}\text { Moisture in dark soil } \\
\text { rich in humus } \\
\text { Moisture in lighter } \\
\text { soil poor in hurnus }\end{array}$ & 13.1 & $11 \cdot 9$ & $12 \cdot 0$ & $\mathbf{1 7 \cdot 5}$ \\
\hline
\end{tabular}

Humus, therefore, keeps the water in the soil and saves it from being lost.

Another beneficial effect of hoeing is to keep down weeds. Weeds overcrowd the plant, shut out light, take food and water, and occupy space. Few plants can compete against weeds, some fail very badly in the struggle. Sow two rows of maize two yards apart; keep one well hoed for a yard on each side and leave the other alone to struggle with the weeds that will grow. Fig. 44 shows the result of this experiment at St George's School. At Rothamsted a piece of wheat was left unharvested in 1882, and the plot has not been touched since; the wheat was allowed to shed its seed 
and to grow up without any attention. Weeds flourished, but the wheat did not; the next year there was but little wheat, and by 1886 only a few plants could be seen, so stunted that one would hardly recognise thẹm.

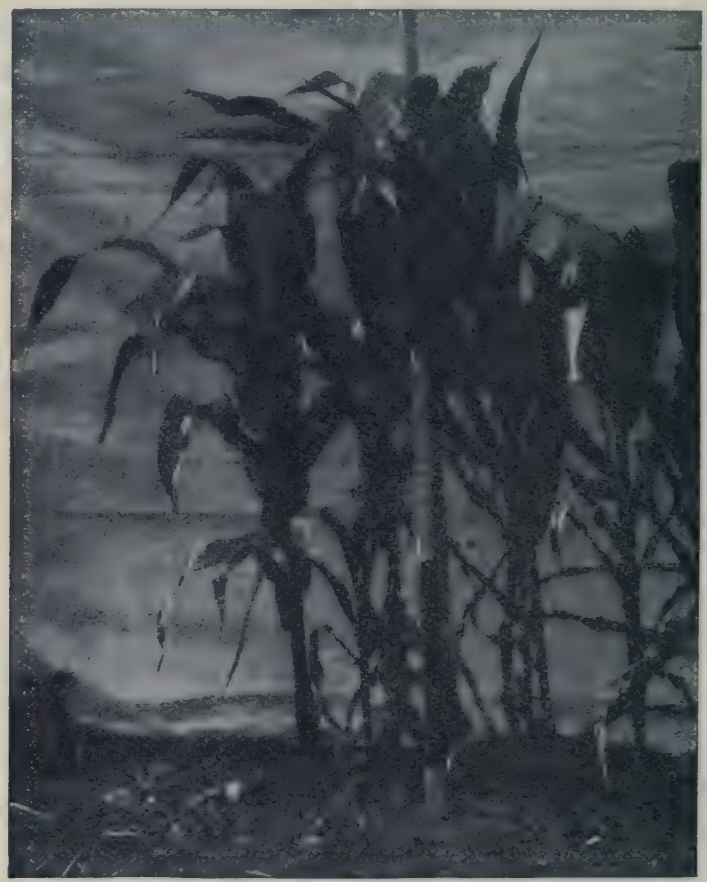

The hoed plot, no weeds

Fig. $44 a$.

Maize cannot competé successfully against weeds

The ground still remains untouched, and is now the dense thicket seen in Fig. 45. Most of our land would become like this if it were neglected for a few years. 
Farmers occasionally leave their ground without a crop for a whole year and cultivate it as often as they can to kill the weeds. This practice is called "fallowing," and is very ancient; it is much less common now

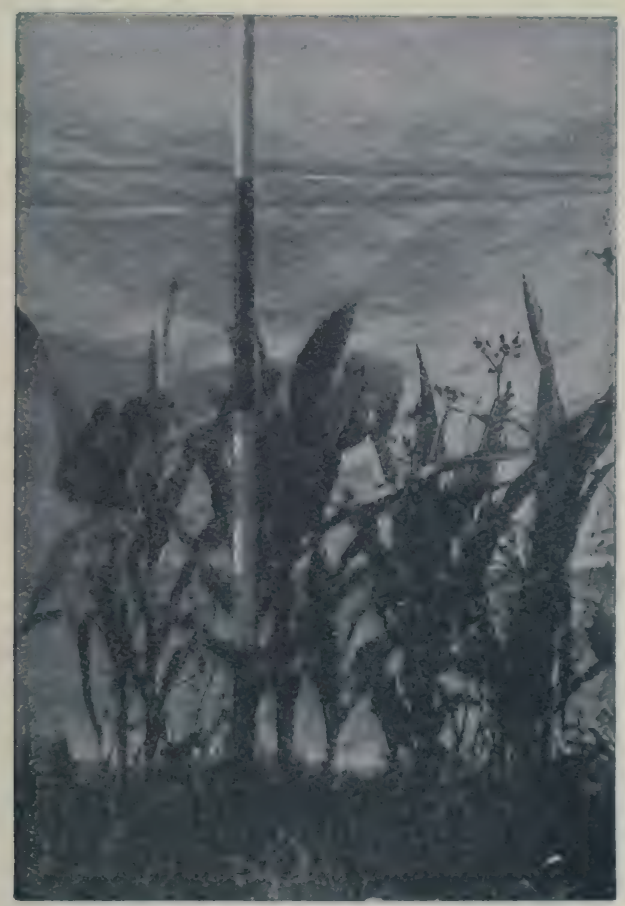

Untouched plot, many weeds

Fig. $44 b$.

that crops like mangolds and swedes are grown, which can, if necessary, be hoed all the summer.

We have already seen ( $p .69)$ that ordinary cultivated plants will not live in a water-logged soil. 
Wherever there is an excess of water it must be removed before satisfactory results can be obtained. Fig. 46 shows a field of wheat in May where the crop is all but killed and only certain weeds survive on a patch of undrained land that lay wet all the winter. Draining land is difficult and somewhat expensive; trenches are first cut to a proper depth, and drain pipes are laid on the bottom, taking care that there is a gentle slope all the way to the ditch. The rain soaks into the soil and gets into the pipes, for they are not joined together like gas or water pipes, but left with little spaces in between; it then runs out into the ditch. Usually only clay soils need drainage, but occasionally sandy soils do also (see pp. 30, 106). A great deal of drainage was carried out in England between 1840 and 1860 , and it led to a marked improvement in agriculture and in country life generally. There is, however, a great deal that wants doing now.

The addition of chalk or lime to soil was found in Chap. III. to improve it very much by making it less sticky and less impervious to air and water. Chalk or lime does more than this. It puts out of action certain injurious substances or acids that may be formed, and thus makes the conditions more favourable for plants and for the useful micro-organisms; farmers and gardeners express this by saying that it "sweetens the soil." A United States proverb runs: "A lime country is a rich country." Very many soils in England are improved by adding lime or chalk. There are considerable areas in the south-eastern and eastern counties where the soil is very chalky; here you find a wonderfully rich assortment of flowers and shrubs. Where there is too much chalk the soil is not fertile, because it lets water 


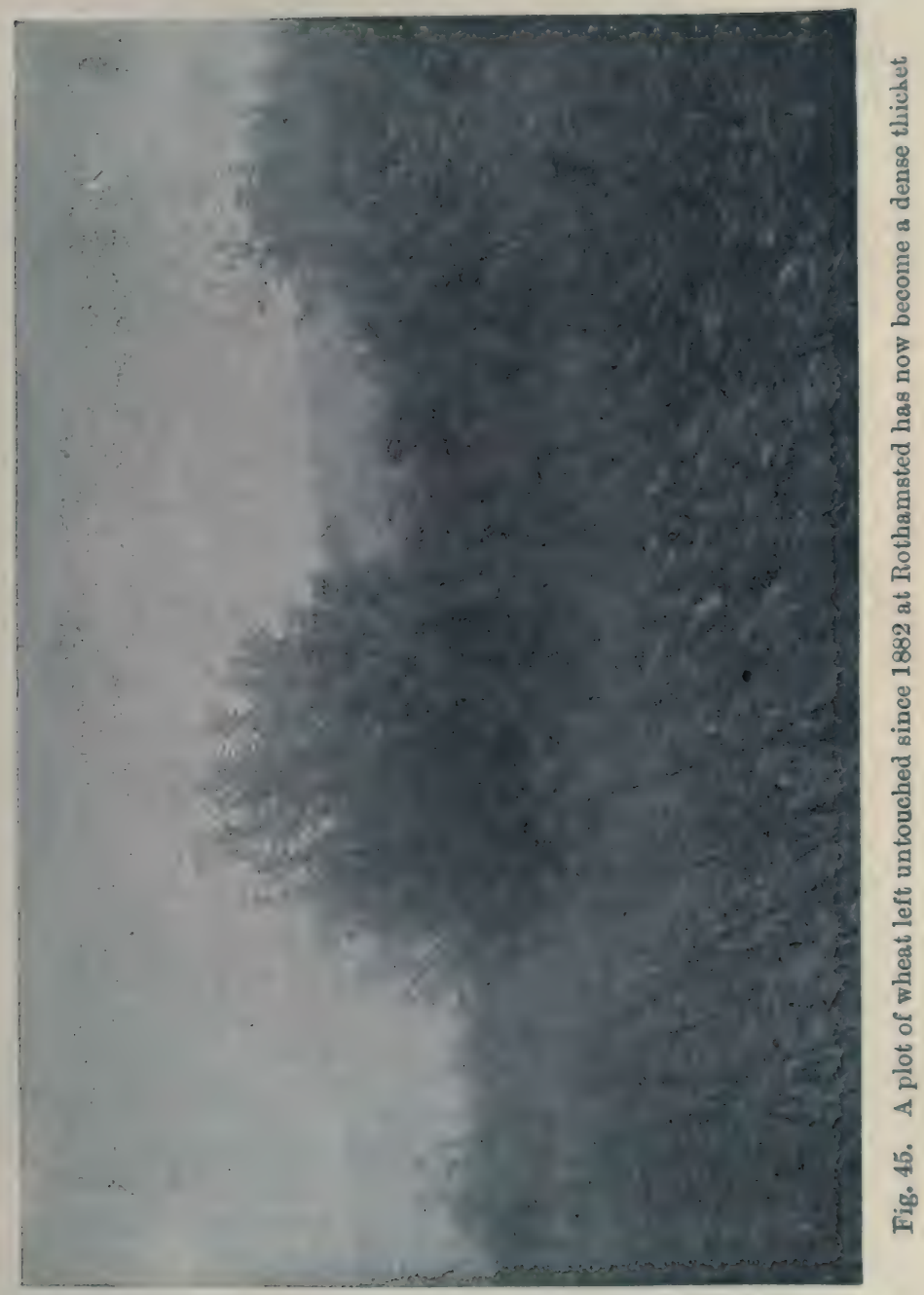


through too easily, as was shown on p. 26: but for this very reason it is admirable for residential purposes.

There are some exceptions to the rule that plants need lime. Some plants will not tolerate it at all; such are rhododendrons, azaleas, foxgloves, spurrey, and broom; wherever you see these growing you may be sure that lime is absent.

Lime really differs from chalk, but changes into it so quickly in the soil that the action of both is almost, though not quite, the same.

Summary. The various things we have learnt in this Chapter are:-

Autumn and winter cultivation are needed to loosen the soil so that rain can soak in and not lie about in pools, and also to facilitate working in spring.

The soil has to be broken down very finely and made rather dry for a seed bed. The seed has to be rolled in and then left entirely alone.

As soon as the little plants are up the soil must be hoed, and the more often this is done the better. Hoeing keeps the soil cool and moist in hot weather, the loose layer acting like a mulch of straw. Anything else that shields the soil from the sun or the wind has the same action but is not so effective as the mulch. Further, hoeing keeps down weeds, which successfully compete against almost any cultivated plants. Humus also prevents the loss of moisture from soils.

Drainage may be necessary to remove excess of water.

Liming or chalking the soil is beneficial, not only because of the improvements mentioned in Chap. III., but also because certain injurious substances are thereby removed. There are, however, some plants that will not tolerate lime. 


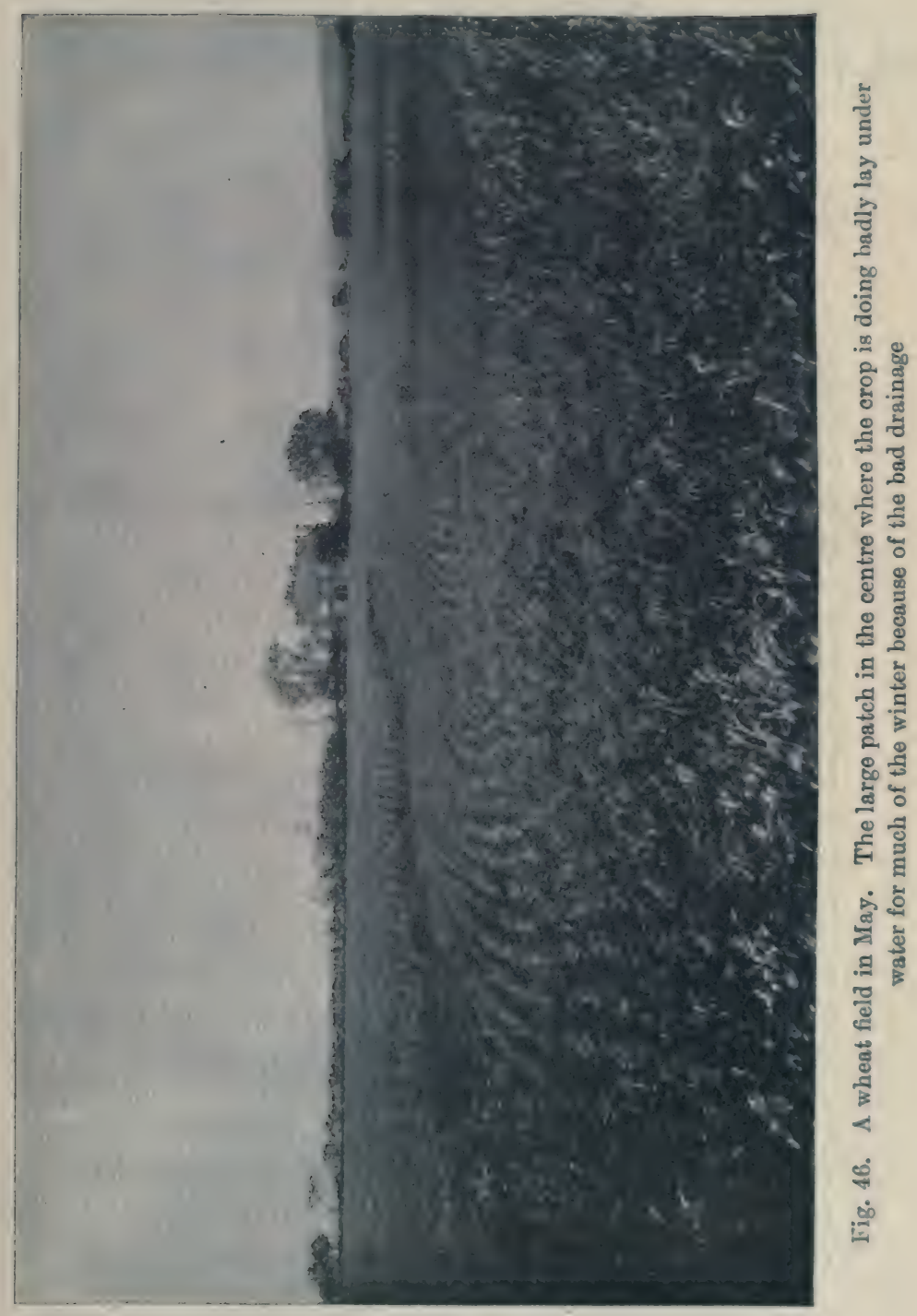




\section{CHAPTER $\mathrm{X}$}

\section{THE SOIL AND THE COUNTRYSIDE}

In this chapter we want to put together much of what we have learned about the different kinds of soil. so that as we go about the country we may know what to look for on a clay soil, a sandy soil, and so on.

We have seen that clay holds. water and is very wet and sticky in winter, while in summer it becomes hard and dry, and is liable to crack badly. "It greets a' winter and girns a' summer," as one of Dr John Brown's characters said of his soil. Clay soils are therefore hard to dig and expensive to cultivate : the farmer calls them heavy and usually prefers to put them into grass because once the grass is up it lasts as long as it is wanted and never needs to be resown. But in the days when we grew our own wheat, before we imported it from the United States and other countries, this clay land was widely cultivated for wheat and beans. So long as wheat was $60 /$ - to $100 /-$ a quarter it was a very profitable crop, but, when some forty years ago it fell to $40 /$ and then lower still, the land either went out of cultivation like the "derelict" farms of Essex, or it was changed to grass land and used for cattle grazing. Great was the distress that followed; some districts indeed were years in recovering. But new methods came in: the land near London was used for dairy 
farming, and elsewhere it was improved for grazing, and the clay districts, although completely changed, are now more prosperous again. Many of the fields still show the ridges or "lands" in which, when they grew wheat, they were laid up to let the water run away, and many of them keep their old names, but these are the only relics of the old days. The land is not, and never was, very valuable. The roads are wide, and on either side have wide waste strips cut up roughly by horse tracks, cart ruts and ant hills. Bracken, gorse, rushes, thistles and brambles grow there, and you may find many fine blackberries in September. The coarse Aira grass is found with its leaves as rough as files. The villages are often built round greens which serve as the village playground, where the boys and young men now play cricket and football, and their forefathers practised archery, played quoits and other games. On a few village greens the Maypole can still be seen, whilst the stocks in which offenders were placed are also left in some places.

The hedges are often high and straggling, and there are numerous woods and plantations containing much oak. Some of the woods are very ancient and probably form part of the primeval forests that once largely covered England. Epping Forest in Essex, the Forest of Blean and the King's Wood in Kent, have probably never been cultivated land. In the days when ships were made of oak these woods and hedges were very valuable, but now they are of little use as sources of timber. Instead they are valued for quite another reason: they afford shelter for foxes and for game birds. The clay districts are and always have been famous for fox hunting; the Pytchley, Quorn, Belvoir, 
and other celebrated packs have their homes in the broad, clay, grassy vales of the Midlands. The vale of Blackmoor and other clay regions are equally famous. The plantations and hedgerows are fine places for primroses and foxgloves, while in the pastures, and especially the poor pastures, are found the ox-eyed daisy and quaking grass, that make such fine nosegays, as well as that sure sign of poverty, the yellow rattle. But many of these poor pastures have been improved by draining, liming, and the use of suitable manures. Although the roads are better than they were (see p. 30) they are still often bad and lie wet for weeks together in winter, especially where the hedges are high. Numerous brick and tile yards may be found and iron ore is not uncommon : in some places it is worked now, in others it is no longer worked and nothing remains of the lost industry save only a few names of fields, of ponds, or of cottages.

A sandy soil is in so many ways the opposite of a clay soil that we shall expect to find corresponding differences in the look of the country. A sandy soil does not hold water: it may get water up from the subsoil to supply the plant (see p. 66), or, if it happens to lie in a basin of clay, it may even be very wet : otherwise it is likely to be too dry for ordinary plants. We may therefore look out for two sorts of sand country, the one cultivated because there is enough water for the crops, and the other not cultivated because the water is lacking. These can readily be found.

We will study the cultivated sands first. As sand is not good plant food (p. 43) these soils want a lot of manure, and so are not good for ordinary farmers. But they are very easy to cultivate-for which reason they 

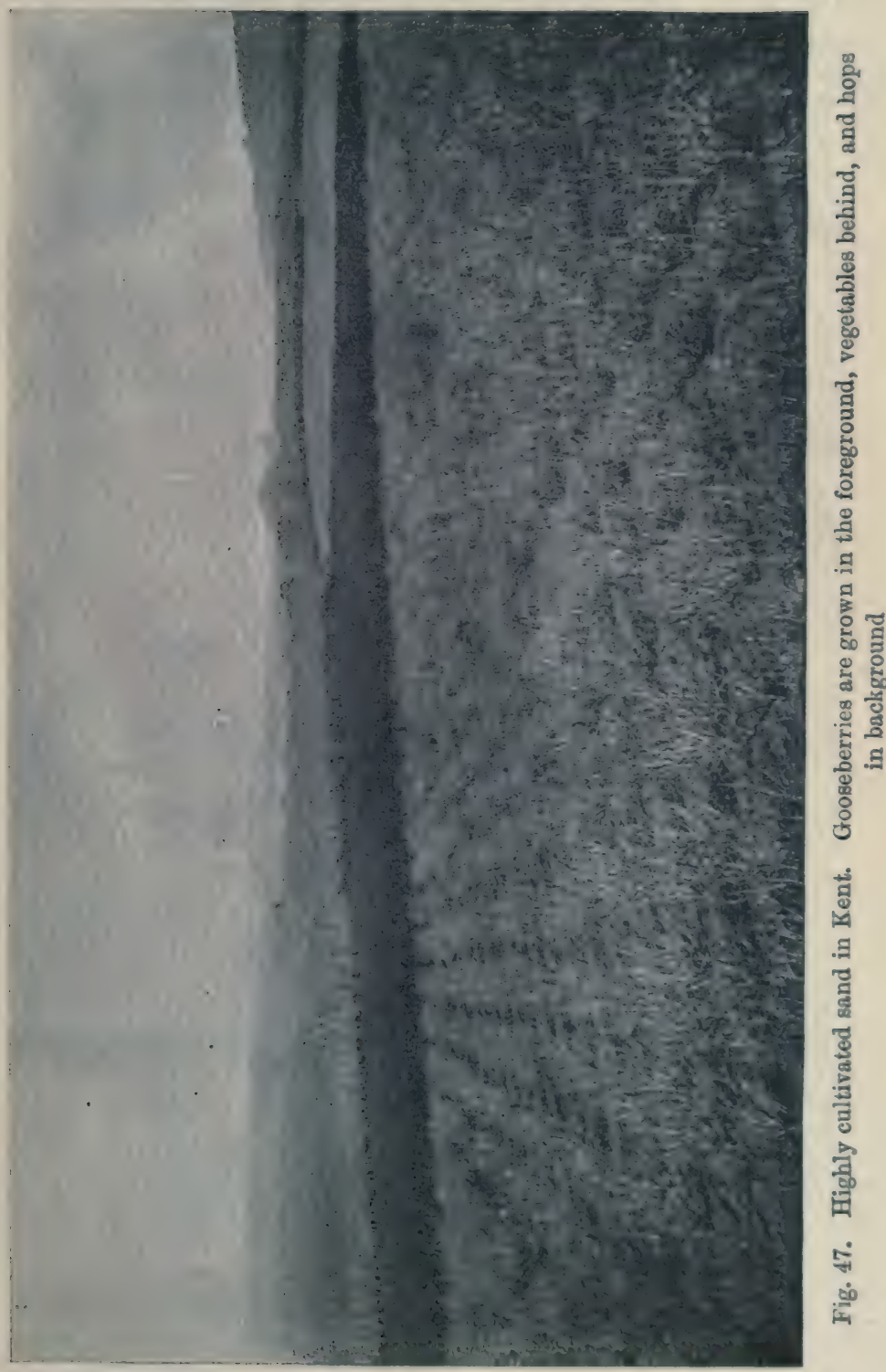
are called light soils-and can be dug at any time; seeds can be sown early, and early crops can be got. Consequently these soils are very useful for men doing special work like fattening winter and spring sheep, or producing special crops like fruit or potatoes, and for market gardeners who grow all sorts of vegetables, carrots, parsnips, potatoes, peas, and so on. Fig. 47 is a view of a highly cultivated sandy region in Kent showing gooseberries in the foreground, vegetables behind, and a hop garden behind that again.

The uncultivated sands are sometimes not really so very different, and some of them, perhaps many of them, might be improved or reclaimed and made to grow these special crops if it were worth while. But they always require special treatment and therefore they have been left alone. In days of old our ancestors disliked them very much ; "villanous, rascally heaths" Cobbett always called them. There were practically no villages and few cottages, because the land was too barren to produce enough food; the few dwellers on the heath, or the "heathen," were so ignorant and benighted that the name came to stand generally for all such people and has remained in our language long after its original meaning was lost. As there were so few inhabitants the heaths used to be great places for robbers, highwaymen, and evildoers generally ; Gad's Hill on the Watling St. between Rochester and Gravesend, Finchley Common, Hounslow Heath and others equally dreaded by travellers of the seventeenth and eighteenth centuries, were barren sandy tracts. But in our time we no longer need to dread them; we can enjoy the infinite charm of the breezy, open country with its brown vegetation, the pink blossom of the bell-shaped heath and the lilac blossom of the 


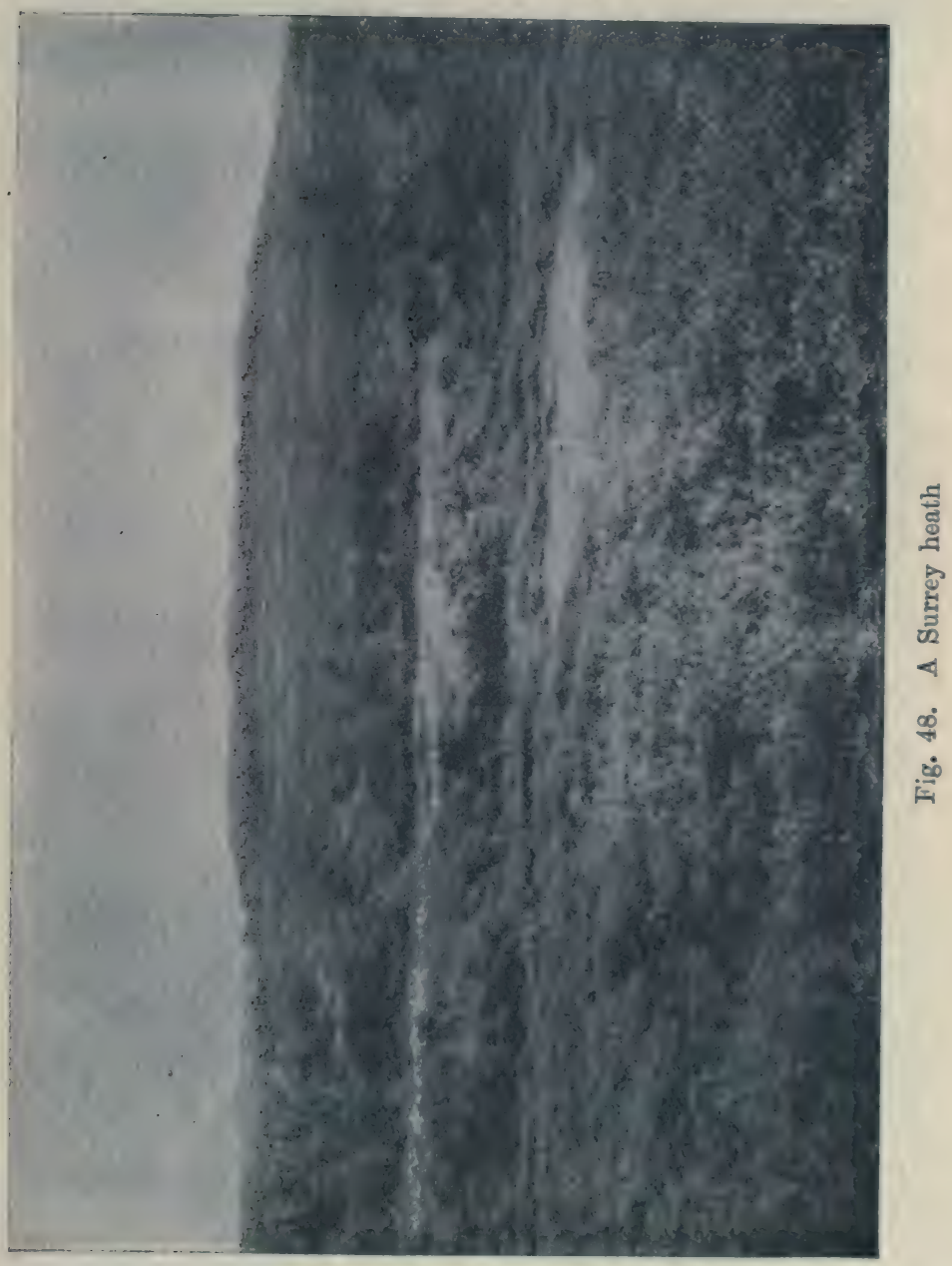


heather, the splashes of yellow from the ragwort or the gorse and the dark pine and larch plantations. In the spring the young shoots of bracken lend a beautiful light green colour to the scene, while in the autumn the faded growth covers it all with a rich brown. People now like to live amid such surroundings, and so these heaths, that have been untouched for so long and are part of the original primeval England as it was in the days of the Britons, are becoming dotted with red bricked and red tiled villas, and are fast losing their ancient character. The heaths are not everywhere dry; there are numerous clay basins where the sand lies wet, where peat forms (see p. 37), and where marsh plants like the bog asphodel, sundew, or cotton grass can be found. In walking over a heath you soon learn to find these wet places by the colour of the grass and the absence of heather. In some places there is a good deal of wood, especially pines, larches, and silver birches: all these are very common on the Surrey sands, willows also grow in the damp places. Fig. 48 shows a Surrey heathBlackheath - with heather, gorse and bracken; with pine-woods in the distance and everywhere some bare patches of sand. Much of the New Forest is on the sand, as also is Bournemouth, famous for its fine pine woods. Fig. 49 is a view of such woods on Wimbledon common. But elsewhere there is no wood: the peasants burn the turf, and so you find their cottages have huge fireplaces: instead of fences round their gardens or round the plantations there are walls made of turf. Such are the Dorchester heaths so finely described by Hardy in The Return of the Native and other novels. Other sands, however, are covered with grass and not with heather, and many of these have a special value 


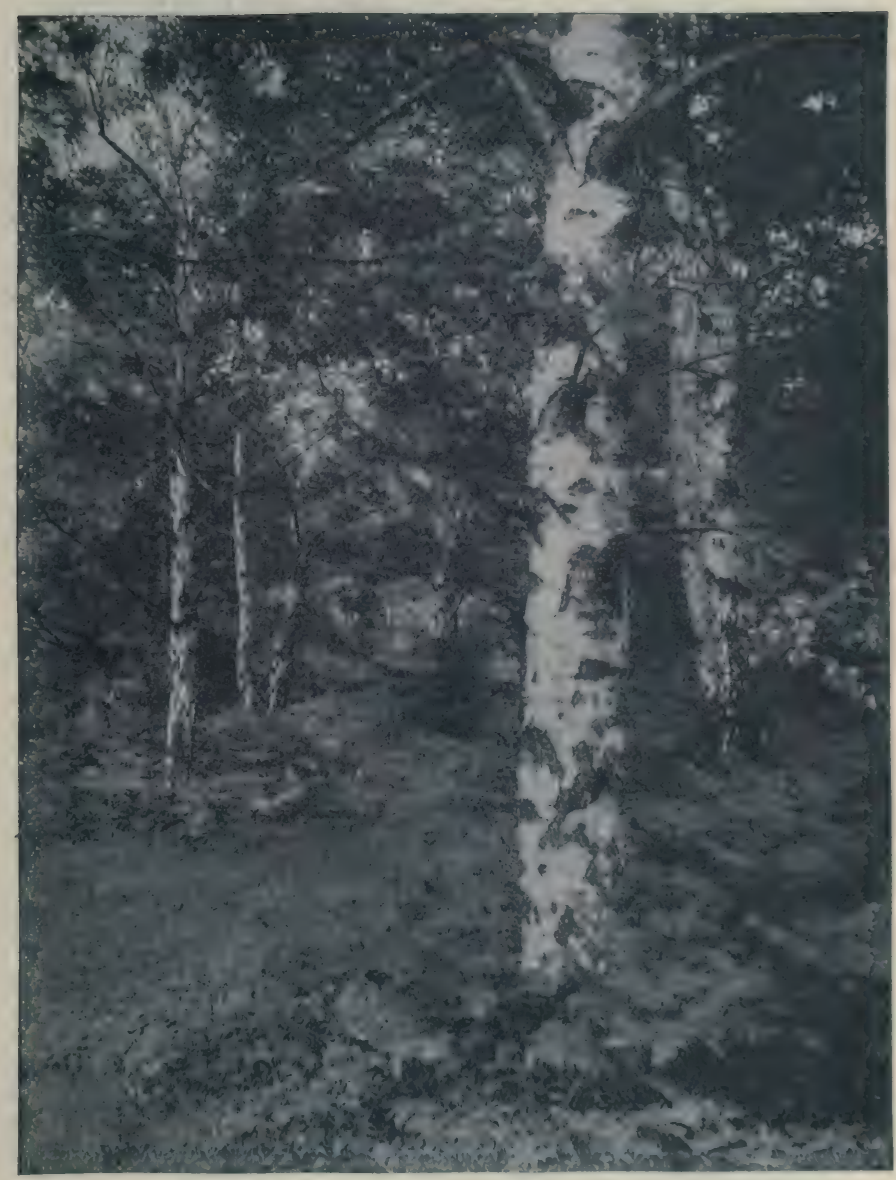

Fig. 49.

Woodland and heather on light sandy soil, Wimbledon Common 
for golf links, especially some of the dry, invigorating sands by the seaside. The famous links at St Andrews, and at Littlestone, are examples.

In between the fertile and the barren sands come a number that are cultivated without being very good. They are much like the others, carrying a vegetation that is usually of the narrow leaved type (p. 72), and not very dense. On the road sides you see broom, heather, heath, harebells, along with gorse and bracken with milkwort nestling underneath: crested dog's tail and sheep's fescue are common grasses, while spurrey, knotweed, corn marigold, are a few of the numerous weeds in the arable fields. Gardens are easily dug, but it is best to put into them only those plants that, like the native vegetation, can withstand drought: vegetable gardens must be well manured and well limed. Fig. 50 shows some of this kind of country in Surrey, the barley field is surrounded by wood and very poor grass on the higher slopes.

It is easy to travel in a sand country because the roads dry very quickly after rain, although they may be dusty in summer. Sometimes the lanes are sunk rather deeply in the soft sand, forming very pretty banks on either side.

Loams, as we have seen (p. 2), lie in between sands and clays: they are neither very wet nor very dry : not too heavy nor yet too light : they are very well suited to our ordinary farm crops, and they form by far the best soils for general farming; wheat, oats, barley, sheep, cattle, milk, fruit and vegetables can all be produced: indeed the farmer on a good loam is in the fortunate position of being able to produce almost anything he finds most profitable. In a loam district that does not 


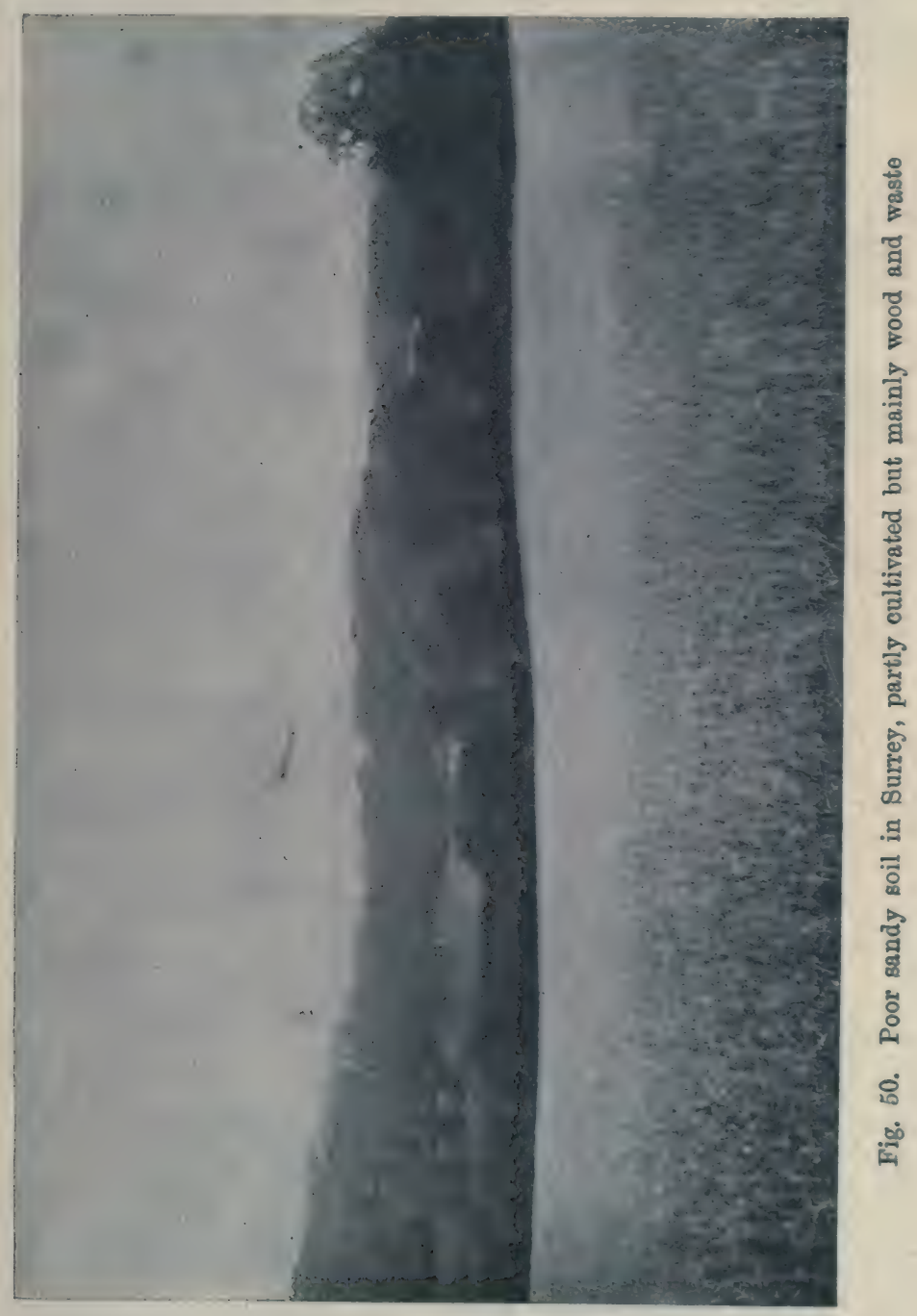


lie too high the land is generally all taken up, even the roads are narrow and there are few commons. The hedges are straight and cut short, the farm houses and buildings are well kept, and there is a general air of prosperity all round. Good elms grow and almost any tree that is planted will succeed. Loams shade off on one side into sand; the very fertile sands already described might quite truly be called sandy loams. On the other side they shade off into clays; the heavy loams used to be splendid wheat soils, but are now, like clays, often of little value. But they form pleasant, undulating country, nicely wooded, and dotted over with thatched cottages; the fields are less wet and the roads are rather better than on the clays. When properly managed they make excellent grass land.

Chalky soils stand out quite sharply from all others: their white colour, their lime kilns now often disused, their noble beech trees, and, above all, the great variety of flowering plants enable the traveller at once to know that he is on the chalk. Many plants like chalk and these may be found in abundance, but some, such as foxgloves, heather, broom or rhododendrons cannot tolerate it at all, and so they will not grow.

Chalk, like sand, is dry, and the roads can be traversed very soon after rain. They are not very good, however; often they are only mended with flints, which occur in the chalk and are therefore easily obtainable, and the sharp fragments play sad havoc with bicycle tyres. The bye roads and lanes are often narrow, winding, and worn deep especially at the foot of the hills, so that the banks get a fair amount of moisture and carry a dense vegetation. Among the profusion of flowers you can find scabious, the bedstraws, vetches, ragwort, 
figwort, and many a plant rare in other places, like the wild orchids; while the cornfields are often yellow with charlock. In the hedgerows are hazels, guelder roses, maples, dogwood, all intwined with long trails of bryony and traveller's joy. In the autumn the traveller's joy produces the long, hairy tufts that have earned for it the name of old man's beard, while the guelder roses bear clusters of red berries. The great variety of flowers attracts a corresponding variety of butterflies, moths and other insects; there are also numbers of birds and rabbits-indeed a chalk country teems with life in spite of the bare look of the Downs. The roads running at the foot of the chalk Downs and connecting the villages and farmhouses built there for the good water supply, are particularly rich in plants because they sometimes cut into the chalk and sometimes into the neighbouring clay, sand or rock. Now and then a spring bursts out and a little stream takes its rise: if you follow it you will generally find watercress cultivated somewhere.

Besides the beech trees you also find ash, sycamore, maples, and, in the church yards, some venerable yews. Usually the chalk districts were inhabited very early: they are dry and healthy, the land can be cultivated and the heights command extensive views over the country, so that approaching enemies could easily be seen. On the chalk downs and plains are found many remains of tribes that lived there in the remote ages of the past, whose very names are now lost. Strange weapons and ornaments are sometimes dug up in the camps where they lived and worked; the barrows can be seen in which they were buried, and the temples in which they worshipped; Stonehenge itself, the best known of all these, lies on the chalk. 
Several of the camps still keep the name the ancient Britons gave them-the Mai-dun, the encampment on the hill, changed in the course of years to Maiden, as in Maiden Hill, near Dorchester, in Dorset, Maiden Bower, near Dunstable, and so on. Some of their roads are still in use to this day, the Icknield Way (the way of the Iceni, a Belgic tribe), the Pilgrim's Way of the southern counties and others.

Even the present villages go back to very ancient times, and the churches are often seven or eight hundred years old.

In places the land is too steep or too elevated to be cultivated, and so it is left as pasture for the sheep or "sheep walk"; where cultivation is possible the fields are large and without hedges, like those shown in Fig. 51; during autumn, winter and spring there are many sheep about, penned or "folded" on the arable land, eating the crops of swedes, turnips, rape, vetches or mustard grown for them, or grazing on the aftermath of sainfoin or grass and clover. So important are sheep in chalk districts that the whole scheme of farming is often based on their requirements, but corn is also a valuable crop, and, especially in dry districts, barley, so that chalk soils are often spoken of as "sheep and barley" soils. Although the pastures are very healthy there is not generally much food or "keep" for the animals during the summer because of the dryness.

The black soil of the fen districts and elsewhere is widely different from any of the preceding. It contains, as its colour shows, a large quantity of combustible material (Chap. V.), which has a great power of holding water. These fens are therefore very wet; until they were drained they were desolate wastes : you may 


\section{The soil and the countryside 113}

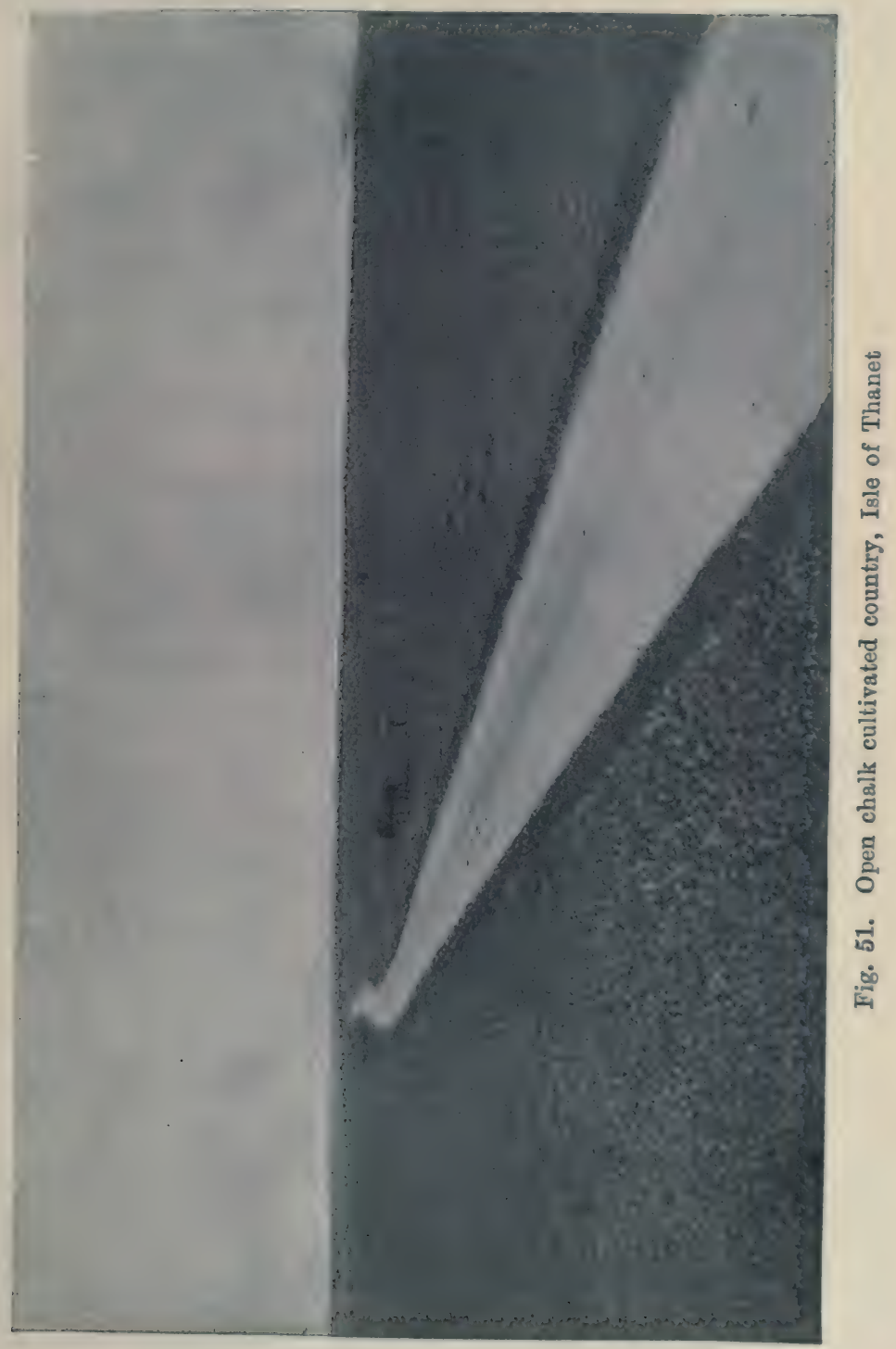


read in Kingsley's Hereward the Walie what they used to be like in old days, and even as late as 1662 Dugdale writes that here "no element is good. The air cloudy, gross and full of rotten harrs ${ }^{1}$; water putrid and muddy, yea, full of loathsome vermin; the earth spongy and boggy; and the fire noisome by the stink of smoking hassocks.". But during the Stuart period wide ditches or drains were dug, into which the water could flow and be pumped into rivers. This reclamation has been continued to the present time, and the black soils as well as the others in the Fen districts can be made very productive.

We have seen that a change in the soil produces a change in the plants that grow on it. The flora (i.e. the collection of plants) of a clay soil is quite different from that of a sandy soil, and both are different from that of a chalk or of a fen soil. In like manner draining a meadow or manuring it alters its flora: some of the plants disappear and new ones come in. Even an operation like mowing a lawn, if carried on sufficiently regularly, causes a change. In all these cases the plants favoured by the new conditions are enabled to grow rather better than those that are less favoured; thus in the regularly mown lawn the short growing grasses have an advantage over those like brome that grow taller, and so crowd them out. When land is drained those plants that like a great quantity of water no longer do quite so well as before, while those that cannot put up with much water now have a better chance. In the natural state there is a great deal of competition among

1 Harr is an old word meaning sea-fog.

2 Hassock is the name given to coarse grass which forms part of the turf burnt in the cottages. 
plants, and only those survive that are adapted to their surroundings. You should remember this on your rambles, and when you see a plant growing wild you should think of it as one that has succeeded in the competition and try to find out why it has been enabled to do so. 


\section{CHAPTER XI}

\section{HOW SOIL HAS BEEN MADE}

\section{Apparatus required.}

The apparatus in Fig. 54. The under surface of the lips of the beakers should be vaselined to prevent the water trickling down the sides.

It is not uncommon to find cliffs or crags in inland places, but they usually show one very striking difference from seaside cliffs. The seaside cliffs may be nearly vertical, but the inland cliffs are not, excepting for a little way at the top; lower down a heap of stones and soil lies piled against the face of the cliff and makes a slope up which you can climb. If you look at the cliff you can find loose fragments of it split off either by the action of freezing water (p. 83) or by other causes ready to roll down if sufficiently disturbed. So long has this been going on that a pile has by now accumulated, and has been covered with plants growing on the soil of the heap. Our interest centres in this soil; no one has carried it there; it must have been made from the rock fragments. When you get an opportunity of studying such a heap, do so carefully; you can then see how, starting from a solid rock, soil has been formed. This breaking down of the rock is called weathering.

The same change has gone on at the top of the cliff. Fragments have split off and the rock has broken 


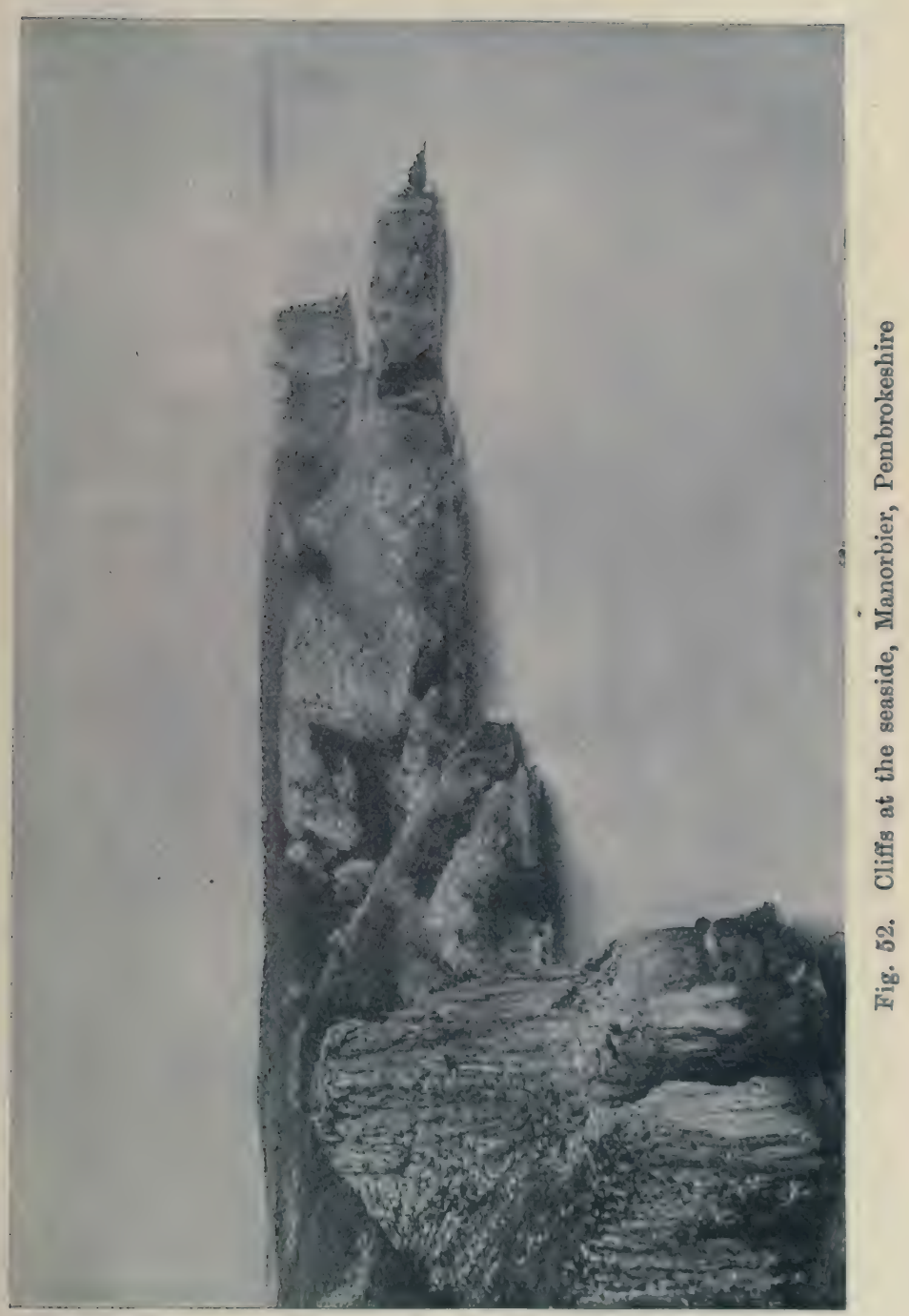


down into soil which stops where it is unless the rain can wash it away. If there are no cliffs where you live you can see the same kind of action in the banks of the lanes, in a disused quarry, gravel pit or clay pit. Wherever a vertical cutting has been made this downward rolling begins and a heap quickly forms, making the vertical cut into a slope. Plants soon begin to grow, and before long it is clear that soil has been made out of the fragments that have rolled down. This process is known as soil formation, but there is another always going on that we must now study. The heap does not invariably lie at the foot of the cliff. If there is a stream, river, or sea at the foot the fragments may be carried away as fast as they roll down: the differences shown in Figs. 52 and 53 between a cliff at the seaside and a cliff inland arise simply in this way. In inland districts great valleys are in course of time carved out, and at the seaside large areas of land have been washed away.

What becomes of the fragments thus carried away by the water? The best way of answering the question would be to explore one of these mountain streams and follow it to the sea, but we can learn a good deal by a few experiments that can be made in the classroom. We want to make a model stream and see what happens to little fragments of soil that fall into it.

Fix up the apparatus shown in Fig. 54. The small beaker $A$ is to represent the narrow mountain stream, the larger one $B$ stands for the wide river, and the glass jar $C$ for the mouth of the river or the sea. Run water through them; notice that it runs quickly through $A$, slowly through $B$, and still more slowly through $C$ : we want it to do this, because the stream flows quickly and the river slowly. 


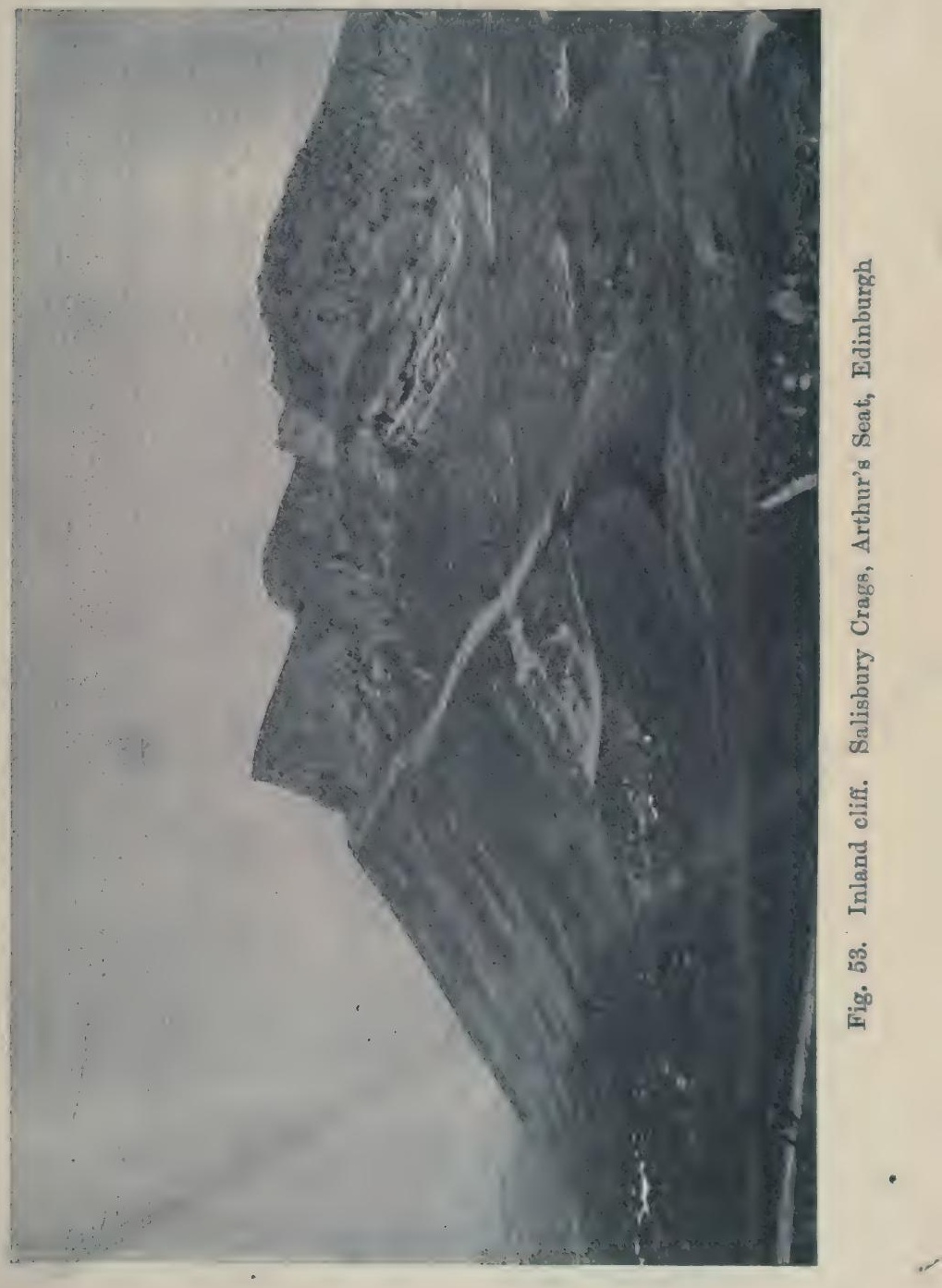


Now put some soil into $A$. At once the soil is stirred up, the water becomes muddy, and the muddy liquid flows into $B$. But very soon a change sets in, the liquid in $\boldsymbol{A}$ becomes clear, and only the grit and stones are left in the bottom: all the mud-the clay and the silt-is washed into $B$. There it stops for a long time, and some of it will never wash out. The liquid flowing into $C$ is clearer than that flowing into $B$. If you keep on putting fresh portions of soil into $A$ you can keep $B$ always muddy, although $\boldsymbol{A}$ is usually

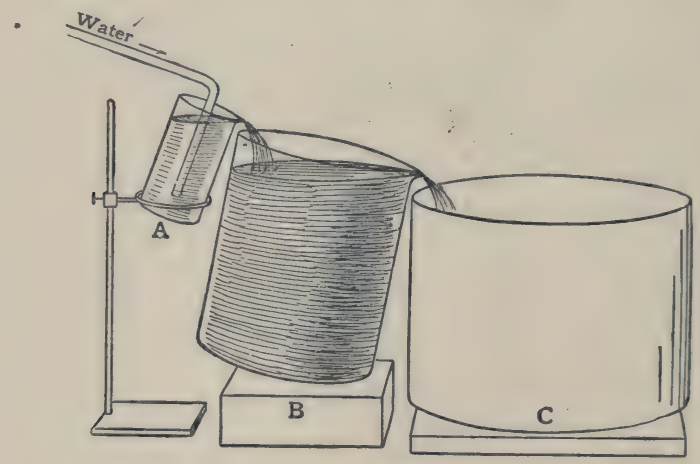

Fig. 54.

Model of a stream. In $A$, where the stream flows quickly, the water is clear and the sediment free from mud. In $B$, where it flows slowly, the water is turbid and the sediment muddy

clear. At the end of the experiment look at the sediment in each beaker : in $\boldsymbol{A}$ it is clear and gritty, in $B$ it is muddy. If you can get hold of some sea water put some of the liquid from $C$ into it : very soon this liquid clears and a deposit falls to the bottom, the sea water thus acting like the lime water on p. 20. 
The experiment shows us that the fine material washed away by a quickly flowing stream is partly deposited when the river becomes wider and the current slower, and a good deal more is deposited by the action of the salt water when the river flows into the sea. The rock that crumbles away inland is spread out on the bed of the river or at its mouth.

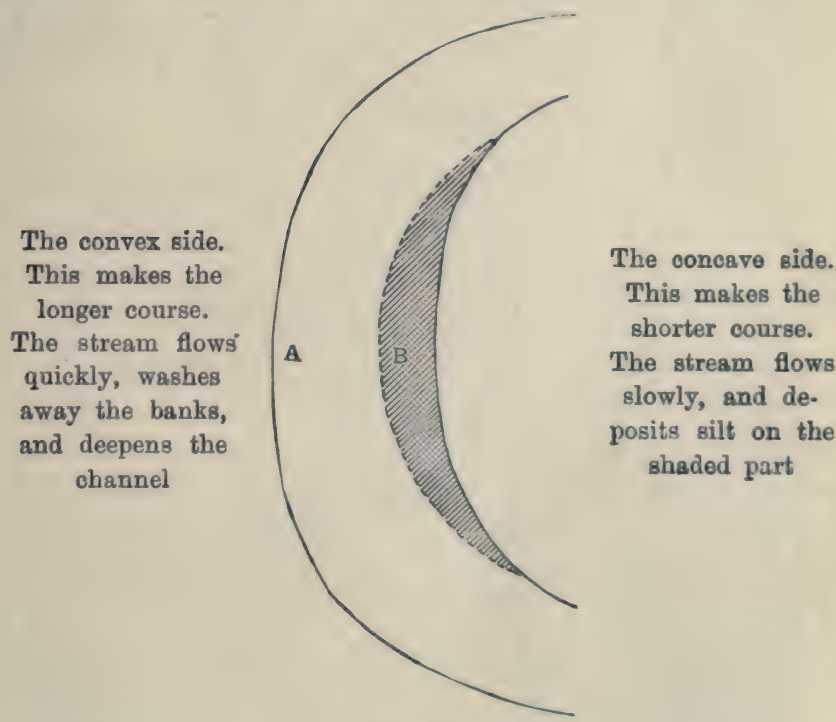

Fig. 55.

The two sides of the river at the bend

The river Stour at Wye showed all these things so clearly that I will describe it; you must then compare it with a river that you know, and see how far the same features occur. At the bridge the stream was shallow and flowed quickly : the bottom was gritty and pebbly, free from mud, and formed a safe place for paddling. Before the bridge was built there had been 
a ford here. But further away, either up or down, the stream was deeper and wider, flowed more slowly, had a muddy bottom, and so was not good for paddling. At one place about a mile away some one had widened out the river to form a lake, but this made the stream flow so slowly (as it was now so much wider) that the silt and clay deposited and the lake became silted up, i.e. it became so shallow that it was little more than a lake of mud. The same facts were brought out at the bend of the river. On its convex side, Fig. 55, the water has rather further to go in getting round the bend than on its concave side $B$; it therefore flows more quickly, and carries away the soil of the bank and mud from the bottom. But on its concave side where it flows more slowly it deposits material. There is at the bend a marked difference in depth at the two sides. On its convex side the stream is rapid and deep, and scours away the bank; on its concave side it is slower, shallower, and tends to become silted up. Thus the bend becomes more and more pronounced unless the bank round $\boldsymbol{A}$ is protected (the other bank of course needs no protection) and the whole river winds about just as syou see in Fig. 56, and is perpetually changing its course, carrying away material from one place, mixing it up with material washed from somewhere else, and then deposits it at a bend or in a pool where it first becomes a mud flat and then dry land. Some, however, is carried out to sea. We need not follow the Stour to the sea; reference to an atlas will show what happens to other rivers. Some of the clay and silt they carry down is deposited at their mouths, and becomes a bar, gives rise to shoals and banks, or forms a delta. The rest is carried away and deposited on the floor of the sea. 


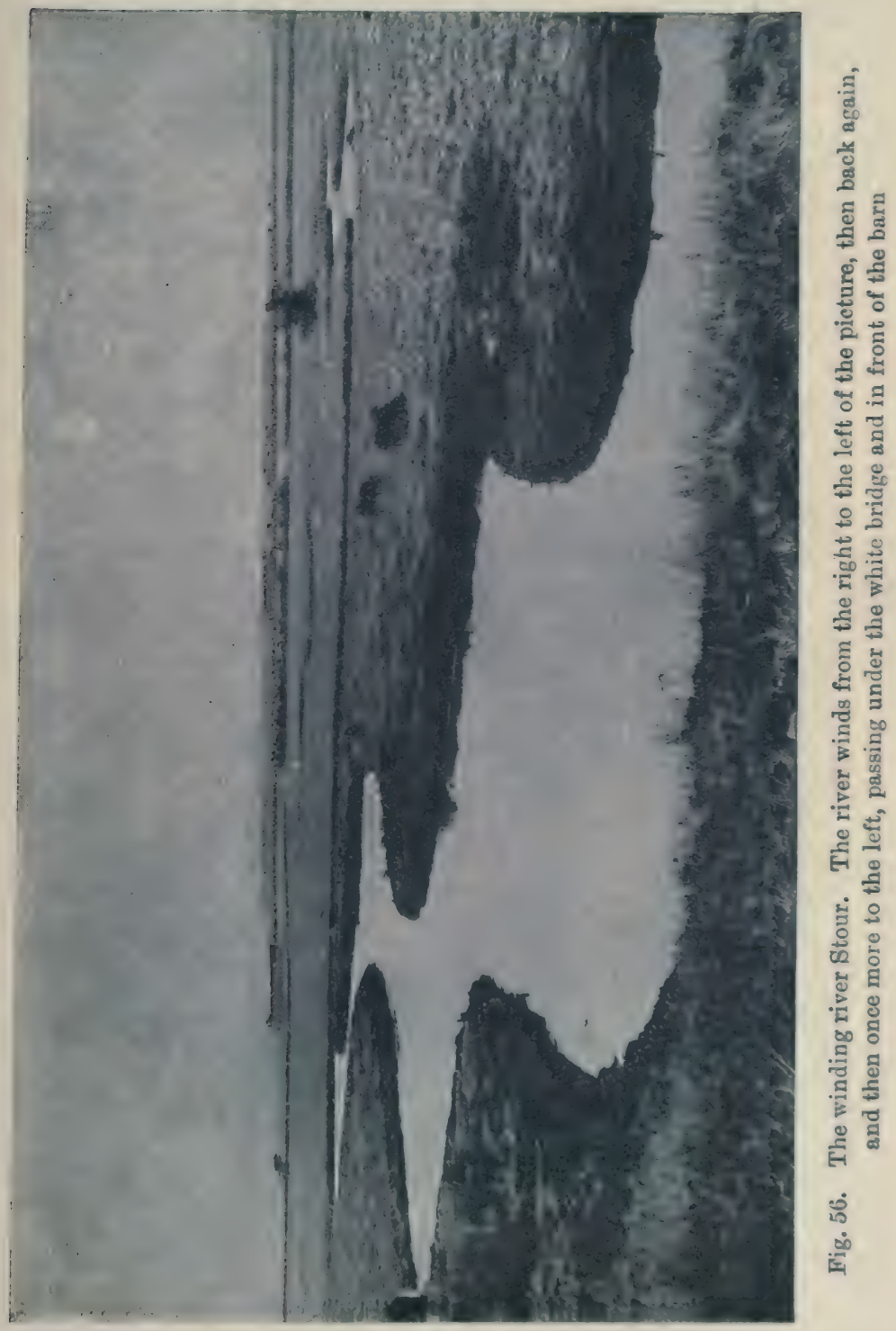


Material washed away by the sea from the coast is either deposited on other parts of the coast, or is carried out and laid on the floor of the sea. Thus a thick deposit is accumulating, and if the sea were to become dry this deposit would be soil. This has actually happened in past ages. The land we live on, now dry land, has had a most wonderful history; it has more than once lain at the bottom of the sea and has been covered with a thick layer of sediment carried from other places. Then the sea became dry land and the sediment became pressed into rock, which formed new soil, but it at once began to get washed away by streams and rivers into new seas, and gave rise to new sediments on the floor of these seas. And so the rock particles have for untold ages been going this perpetual round: they become soil ; they are carried away by the rivers, in time they reach the sea; they lie at the bottom of the sea while the sediment gradually piles up : then the sea becomes dry land and the sediments are pressed into rocks again. The eating away of the land by water is still going on : it is estimated that the whole of the Thames valley is being lowered at the rate of about one inch in eight hundred years. This seems very slow, but eight hundred years is only a short time in geology, the science that deals with these changes.

Water does more than merely push the rock particles along. It dissolves some of them, and in this way helps to break up the rock. Spring water always contains dissolved matter, derived from the rocks, some of which comes out as "fur" in the kettles when the water is boiled.

Rocks are also broken up by other agents. There is nearly always some lichen living on the rock, and if you 
peel it off you can see that it has eaten away some of the rock. When the lichen dies it may change into food for other plants.

We have learnt these things about soil formation. First of all the rocks break up into fragments through the splitting action of freezing water, the dissolving action of liquid water, and other causes. This process goes on till the fragments are very small like soil particles. Then plants begin to grow, and as they die and decay they give rise to the black humus that we have seen is so valuable a part of the soil (p. 51). This is how very many of our soils have been made. But the action of water does not stop at breaking the rock up into soil; it goes further and carries the particles away to the lower parts of the river bed, or to the estuary, to form a delta, and mud flats that may be reclaimed, like Romney Marsh in England and many parts of Holland have been. Many of our present soils have been formed in this way. Finally the particles may be carried right away to sea and spread out on the bottom to lie there for many ages, but they may become dry land again and once more be soil.

One thing more we learnt from the river Stour. Why did it flow quickly at the bridge and slowly elsewhere? We knew that the soil round the bridge was gravelly, whilst up and down the stream it was clayey. The river had not been able to make so wide or so deep a bed through the gravel as it had through the clay, and it could therefore be forded here. We knew also that there was a gravel pit at the next village on the river, where also there was a bridge and had been a ford, and so we were able to make a rough map like Fig. 57, showing that fords had occurred at the gravel 
patches, but not at the clay places. Now it was obvious that an inn, a blacksmith's forge, and a few shops and cottages would soon spring up round the ford, especially as the gravel patch was better to live on than the clay round about, and so we readily understood why our village had been built where it was and not a mile up or down the stream. Almost any river will show the same things: on the Lea near Harpenden we found the river flowed quickly at the ford (Fig. 58), where there was a hard, stony bottom and no mud: whilst above and below the ford the bottom was muddy and the stream flowed more slowly. At the ford there is as usual a

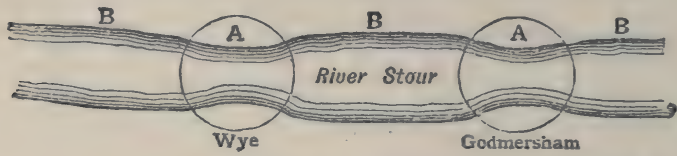

Fig. 57.

Sketch map showing why Godmersham and Wye arose where they did on the Stour. At $A$, the gravel patch, the river has a hard bed and can be forded. A village therefore grew up here.

At $B$, the clay part, the river has a soft bed and cannot be forded. The land is wet in winter, and the banks of the stream may be washed away. It is therefore not a good site for a village

small village. The Thames furnishes other examples : below Oxford there are numerous rocky or gravelly patches where fords were possible, and where villages therefore grew up. Above Oxford, however, the possibilities of fording were fewer, because the soil is clay and there is less rock; the roads and therefore the villages grew up away from the river. 


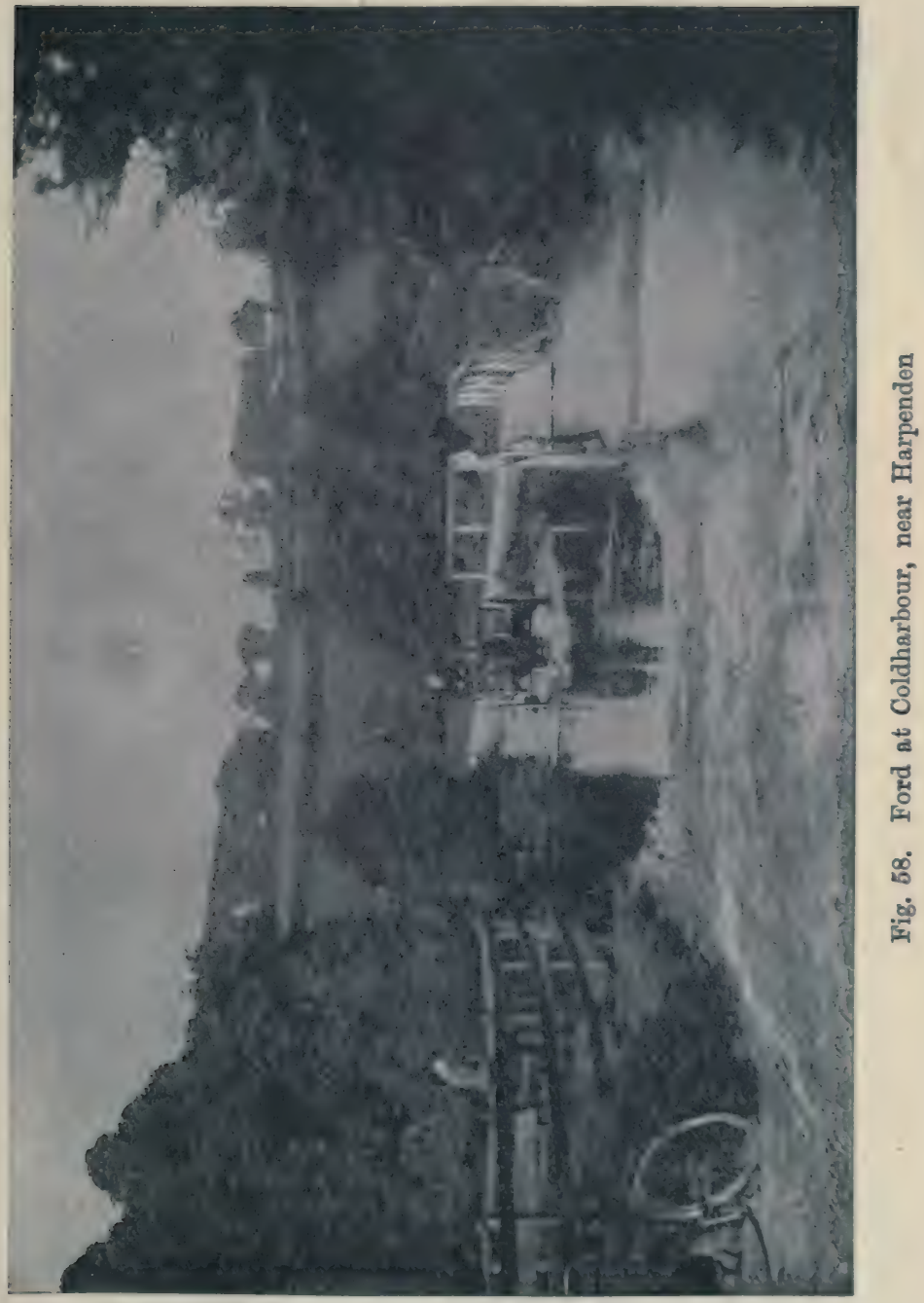




\section{APPENDIX}

The teacher is advised to procure, both for his owu information and in order to read passages to the scholars:

Gilbert White, Natural History of Selborne.

Charles Darwin, Earthworms and Vegetable Mould (Murray).

A. D. Hall, The Soil (Murray).

E. J. Russell, Soil conditions and plant growth (Longmans).

Mr Hugh Richardson has supplied me with the following list of questions, through many of which his scholars at Bootham School, York, have worked. They are inserted here to afford hints to other teachers and to show how the lessons may be varied. T'hey should also prove useful for revising and testing the scholars' knowledge.

1. Collect samples of the different soils in your neighbourhood - garden soil, soil from a ploughed field, from a mole-hill in a pasture field, leaf mould from a wood, etc. Collect also samples of the sub-soils, sand, gravel, clay, peat.

2. Supplement your collection by purchasing from a gardener's shop some mixed potting soil and also the separate ingredients used to form such a mixture-silver sand, leaf mould, peat.

3. How many different sorts of peat can you get samples of ? Peat mould, peat moss litter, sphagnum moss, turf for burning, dry moor peat?

4. Find for what different purposes sand is in use, such as mortar making, iron founding, scouring, bird cages, and obtain samples of each kind. 


\section{Appendix}

Analysis of Garden Soil. About a handful of soil will be required by each pupil.

5. Describe the appearance of the soil. Is it fine or in lumprs? Does it seem damp or dry? Can you see the separate particles of mineral matter? How large are these? Is there any evidence of vegetable matter in the soil ?

6. Put some of the soil in an evaporating basin and over this place a dry filtering funnel. Warm the basin gently. Is any moisture given off ?

7. Dry some of the soil at a temperature not greater than that of boiling water, e.g. by spreading it out on a biscuit tin lid, and laying this on a radiator. How have the appearance and properties of the soil been changed by drying?

8. Crumble some of the dried soil as finely as you can with your fingers. Then sift it through a sheet of clean wire gauze. What fraction of the soil is fine enough to go through the gauze? Describe the portion which will not pass through the gauze. Count the number of wires per linear inch in the gauze.

9. Mix some of the soil with water in a flask. Let it stand. How long does it take before the water becomes quite clear again ?

10. Mix some more soil with water. Let it settle for 30 seconds only. Pour off the muddy water into a tall glass cylinder. Add more water to the remaining soil, and pour off a second portion of muddy water, adding it to the first, and so on until all the fine mud is removed from the soil. Allow this muddy water ample time to settle.

11. When the fine mud has settled pour off the bulk of the water; stir up the mud with the rest of the water ; transfer it to an evaporating basin, and evaporate to dryness.

12. Does this dried mud consist of very tiny grains of sand or of some material different from sand? Can you find out with a microscope?

13. If the mud consists of real clay and not of sand it should be possible to burn it into brick. Moisten the dried mud again. Roll it if you can into a round clay marble. Leave this to dry slowly for a day. Then bake it either in a chemical laboratory furnace or in an ordinary fire.

14. Return to the soil used in Question 10, from which only the fine mud has been washed away. Pour more water on to it, shake it 
well, and pour off all the suspended matter without allowing it more than 5 seconds to settle. Repeat the process. Collect and dry the poured off material as before. What is the material this time, sand or clay?

15. Wash the remaining portion of the soil in Question 14 clean from all matter which does not settle promptly. Are there any pebbles left? If so, how large are they, and of what kind of stone?

16. Take a fresh sample of the soil. Mix it with distilled water in a flask. Boil the mixture. Allow it to settle. Filter. Divide the filtrate into two portions. Evaporate both, the larger portion in an evaporating basin over wire gauze, the smaller portion in a watch glass heated by steam. Is any residue left after heating to dryness?

17. Take a fresh sample of soil. Spread it on a clean sand bath and heat strongly with a Bunsen flame. Does any portion of the soil burn? Is there any change in its appearance after heating?

18. To a fresh sample of soil add some hydrochloric acid. Is there any effervescence? If so, what conclusions do you draw?

19. Make a solution of soil in distilled water, and filter as before. Is this solution acid, alkaline or neutral? Are you quite certain of your result? Did you test the distilled water with litmus paper? And are you sure that your litmus does not contain excess of free acid or free alkali?

\section{Peat.}

20. Examine different varieties of peat collected (see Question 2) and describe the appearance of each.

21. Burn a fragment of each kind of peat on wire gauze. What do you notice?

22. Boil some peat with distilled water and filter the solution. What colour is it? Can you tell whether it is acid, neutral or alkaline? Evaporate some of the solution to dryness.

\section{Out-of-doors.}

23. Describe the appearance of the soil in the flower beds (a) during hard frost, $(b)$ in the thaw which follows a hard frost, (c) after an April shower, $(d)$ in drought at the end of summer, (e) in damp October weather when the leaves are beginning to fall.

24. Is the soil equally friable at different times of the year? 


\section{Appendix}

25. In what way do dead leaves get carried into the soil ?

26. Can you find the worm holes in a garden lawn? in a garden path?

27. Take a flower bed or grass plot of small but known area (say 3 yards by 2 yards) and a watering can of known capacity (say 3 gallons). Find how much water must be added to the soil before some of the water will remain on the surface. What has been the capacity of the soil in gallons per square yard?

28. Take two thermometers. Lay one on the soil, the other with its bulb 3 inches deep in the soil. Compare their temperatures at morning, noon and night.

29. Find from the 25-inch Ordnance map the reference numbers of the fields near your school. Make a list of the fields, showing for what crop or purpose each field is being used. 


\section{INDEX}

Acid waters, 40

Air in soil, 16, 70, 95

Bars in estuaries, 122

Black soils, 36

Blowing sands, 22

Bricks, 10, 16-18

Chalk, 26, 96

Chalk soils, 110-112

Clay, 6, 9-21

Clay soils, 75, 100-102

Cliffs, 116-119

Darwin's experiments, 11, 56

Deltas, 122

Drainage, 19, 96

Dwellers in the soil, 53-63

Earthworms, 54-56

Error of experiment, 48

Fallow, 44, 95

Fens, 112

Flora, 114

Fords, 126

Frost, action of, on soil, 83

Grassland, 75

Grit, 6

Hales's experiment, 73

Heaths, 104

Heavy soils, 100

Hoeing, 86-93

Humus, 36, 51, 93, 125

Hypotheses, 36

Land slips, 12

Leaf mould, 33

Light soils, 104

Lime, action of, on clay and soil, 19-21, 96-98

Lime water, 19

Loams, 2, 65, 108
Marsh gas, 40

Micro-organisms, 56-62

Moorland, 80

Mulch, 87, 90

Peat, 37-40, 130

Peat bogs, overflow of, 38

Perspiration of plants, 74

Plant food, 41-52, 62

Plant requirements, 64

Ploughing, 82

Pot experiments, 41-52, 54, 69, 71

Roads, 30-32, 101-112

Rolling the soil, 84

Sand, 6, 22-32, 41

Sand dunes, 22

Sandy soils, 68-72, 102-108

Shrinkage of clay, 10

Silt, 7

Soil sampler, 82,88

Sowing seed, 84

Springs, 24-31, 111

Subsoil, 2, 4, 42, 48-51

Swelling of clry, 11

Swelling of peat, 38

Temperature of soil, $86-93$

Tilth, 86

Van Helmont's experiment, 46

Villages, situation of, 24, 30, 126

Wastes, 101, 104

Water content of soil, 88-93

Water, movement of in soils, 6568

Water supply and plant growth, 69-74

Weathering, 116

Weeds, 94, 97

Woodland, 80, 101 




\section{PLEASE DO NOT REMOVE CARDS OR SLIPS FROM THIS POCKET}

\section{UNIVERSITY OF TORONTO LIBRARY}

Acric Russell, E. J. (Edmond John)

50i.7. Lessons on soil

BioMed. 
